Abnormalities in the psoriatic non-lesional skin

\author{
Ph.D. Thesis
}

Barbara Konczné Gubán

Szeged

2016 


\title{
Abnormalities in the psoriatic non-lesional skin
}

\author{
Ph.D. Thesis
}

\section{Barbara Konczné Gubán}

Supervisor:

Prof. Dr. Zsuzsanna Bata-Csörgő

Graduate School of Clinical Medicine Department of Dermatology and Allergology University of Szeged, Szeged, Hungary 


\section{TABLE OF CONTENTS}

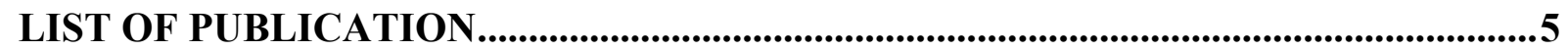

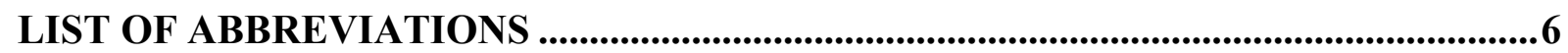

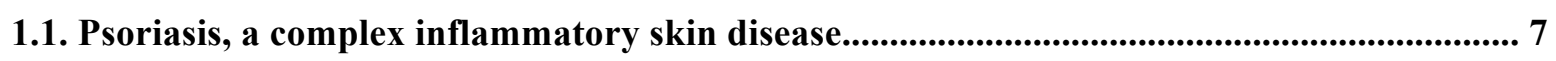

1.2. Structure and function of fibronectin .............................................................................................. 9

1.2.1. The role of fibronectin-binding integrins .......................................................................... 9

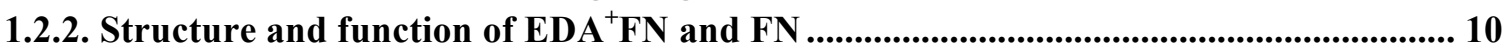

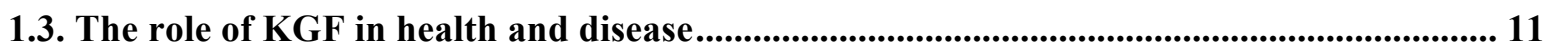

1.3.1. Structure and function of KGF ................................................................................ 11

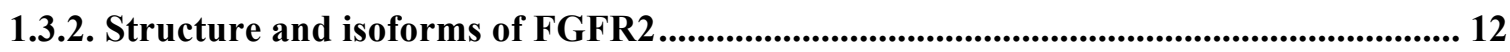

1.3.3. FGF and FGFR signaling network......................................................................... 13

1.3.4. Autocrine and paracrine signaling roles of KGF and FGFR2 in pathophysiology and

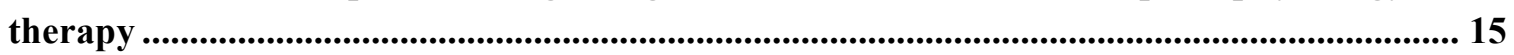

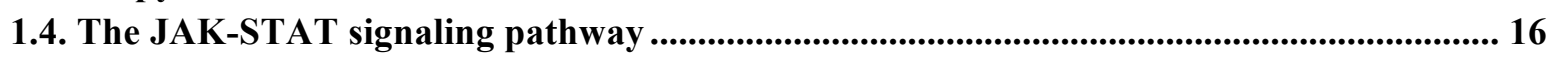

1.4.1. The role of the JAK-STAT signaling pathway in inflammation and immunity ........... 16

1.4.2. Disruption of STAT1 signaling in human diseases ....................................................... 17

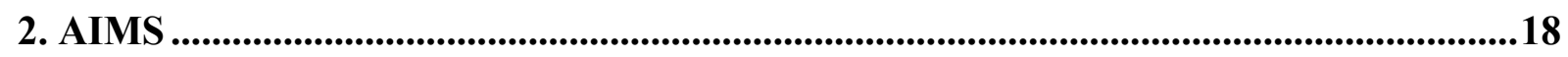

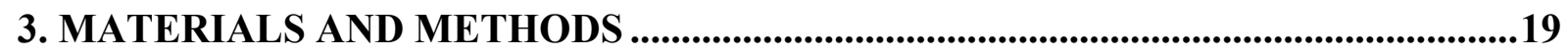

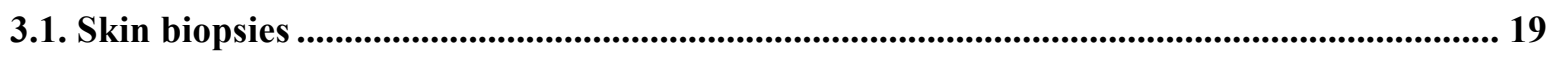

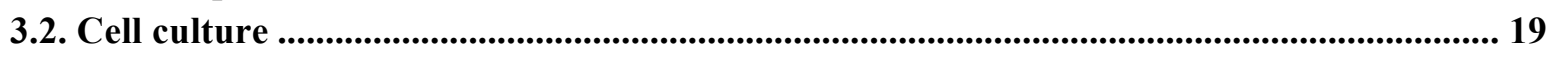

3.3. RNA extraction and real-time quantitative reverse transcription polymerase chain

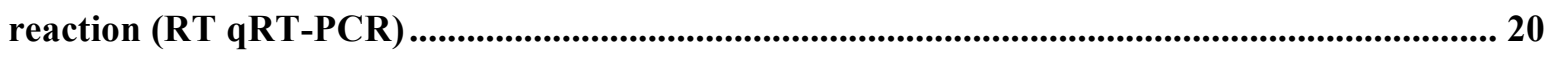

3.4. Immunofluorescent and immunohistochemistry staining........................................................ 21

3.5. Flow cytometry .................................................................................................................................. 22

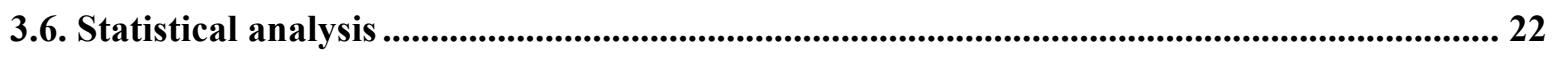

3.7. Bioinformatics analysis and model construction .................................................................... 23

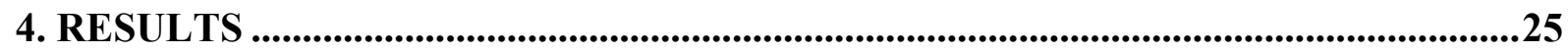

4.1. Altered protein expression of $\alpha_{5}$ integrin, $\mathrm{EDA}^{+} \mathrm{FN}$, KGF and FGFR2 in psoriatic NL skin

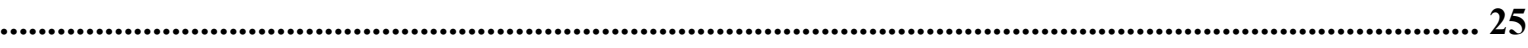

4.2. Determining temporal changes in protein production for downstream analysis ............... 27

4.3. KGF treatment of healthy human fibroblasts leads to the elevation of $\mathrm{EDA}^{+} \mathrm{FN}$ production

4.4. Expression of FGFR2 splice variants in fibroblasts, melanocytes and keratinocytes ........ 31

4.5. MAPK signaling is involved in the regulation of $\mathrm{EDA}^{+} \mathrm{FN}$ controlled by KGF in healthy

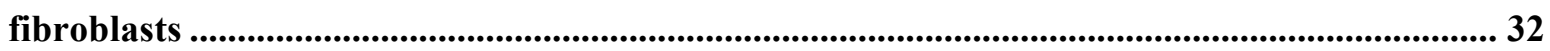

4.6. Inhibition of the RAS-RAF-MAPK, PI3-AKT and STAT signaling pathways affect

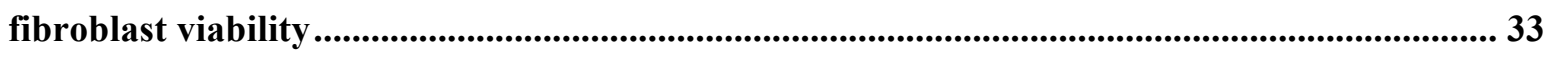

4.7. Abnormal STAT1 activation in psoriatic skin plays a role in the regulation of both $F N$ and

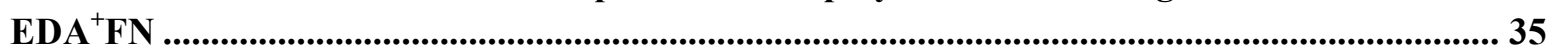




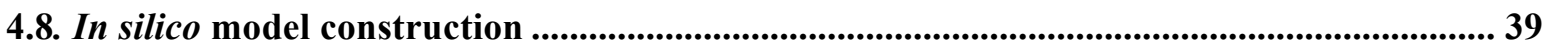

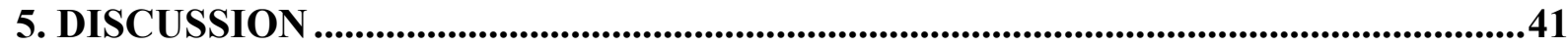

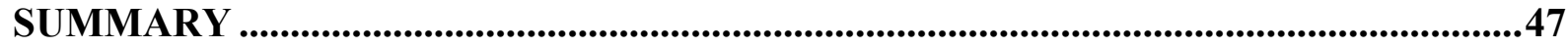

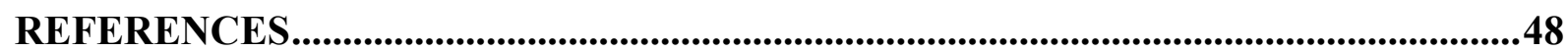




\section{LIST OF PUBLICATION}

Publications directly related to the subject of the dissertation

I. Guban B, Vas K, Balog Z, Manczinger M, Bebes A, Groma G, Szell M, Kemeny L, Bata- Csorgo Zs

Abnormal regulation of fibronectin production by fibroblasts in psoriasis. $\mathrm{Br}$ J Dermatol. 2016 Mar; 174(3):533-541. doi: 10.1111/bjd.14219. Epub 2016 Jan 3. IF: 4.275

II. Gubán B, Kui R, Képíró L, Bebes A, Groma G, Kemény L, Bata-Csörgő Zs Abnormal STAT1 activation in psoriasis

Hungarian Journal of Dermatology and Venerology Review, 2016 February, 92:1821. doi: $10.7188 /$ bvsz.2016.92.1.3. 


\section{LIST OF ABBREVIATIONS}

AKT: v-akt murine thymoma viral oncogene homolog

AP-1: activator protein 1

BSA: bovine serum albumin

COMP: cartilage oligomeric matrix protein

DAPI: 4',6-diamidino-2-phenylindole

ECM: extracellular matrix

$\mathbf{E D A}^{+} \mathbf{F N}$ : extra-domain-A containing fibronectin

EDTA: ethylene-diamine-tetraacetic

ERK: extracellular signal-regulated kinase

FGF: fibroblast growth factor

FGF7: fibroblast growth factor 7

FGFR2: fibroblast growth factor receptor 2

FN: fibronectin

FRS2: FGFR substrate 2

GAB1: GRB2-associated binding protein 1

GRB2: growth factor receptor-bound protein 2

GWAS: genome-wide association studies

H: healthy

HSPG: heparan sulphate proteoglycan

IFN $\gamma$ : interferon gamma

Ig: immunoglobulin

IL-1: interleukin-1

IL-6: interleukin-6

IL-8: interleukin-8

IL-12: interleukin-12

IRF-1: interferon regulated factor 1

JAK: Janus kinase

KGF: keratinocyte growth factor

L: lesional

MAPK: mitogen activated protein kinase

MEK1: MAPK/ERK kinase 1

MMP9: matrix metalloproteinase 9

MS: multiple sclerosis

NF-кB: nuclear factor $\kappa B$

NL: non-lesional

PASI: psoriasis area severity index

PBS: Phosphate buffered saline

PI3: phosphoinositide 3-kinase

PLC $\gamma$ : phospholipase C gamma

PPIG: peptidyl-prolyl cis-trans isomerase

PSORS: psoriasis susceptibility

RAS: rat sarcoma

RAF: rapidly accelerated fibrosarcoma

RFI: relative fluorescence intensity

SDS-PAGE: sodium dodecylsulfate-polyacrylamide gel electrophoresis

SH2: Src homology 2

SNP: single nucleotid polimorphism

SOCS1: suppressor of cytokine signaling 1

SOS: son of sevenless

STAT1: signal transducer and activator of transcription 1

STAT3: signal transducer and activator of transcription 3

TK: tyrosin kinase

TLR4: Toll-like receptor4

TM: transmembrane 


\section{INTRODUCTION}

\subsection{Psoriasis, a complex inflammatory skin disease}

Psoriasis is a multifactorial skin disorder affecting about 2-3\% of the population worldwide, although it is more prevalent in European, American and Canadian populations (1). The most common form of chronic plaque psoriasis is Psoriasis vulgaris, which is characterized by epidermal hyperplasia, intensified and abnormal dermal angiogenesis and infiltration of inflammatory cells (Figure 1). Altered cellular composition characterized by hyperproliferation of keratinocytes and massive infiltration of immune cells is initiated by secreted cytokines of activated resident immune cells, dendritic cells, macrophages and innate immune cells as well as by keratinocytes themselves in the psoriatic skin $(2,3)$.

Both genetic risk factors and environmental triggers are known to contribute to the pathomechanism of psoriasis. Psoriasis-susceptibility (PSORS) loci are areas of chromosomes thought to associate with the manifestation or maintenance of psoriasis. At least 15 different PSORS have been identified by linkage analysis in family-based studies, for example PSORS1 is the strongest susceptibility locus known as $\operatorname{HLA-C}(4,5)$. In recent years, genome-wide association studies (GWAS) have identified single nucleotide polymorphisms (SNPs) in 50 different regions of the human genome that are connected with psoriasis. The function of these polymorphic genes is comprehensive, such as antigen presentation (HLA-Cw6), T cell development and polarization (STAT3), innate immunity (CARD14) and negative regulators of immune responses (SOCS1) (1).

One of the environmental factors involved in psoriasis is the streptococcal infection of the tonsils, where even after the infection is cleared, $\mathrm{T}$ cells remain auto-reactive to keratin peptides $(6,7)$. Acute stressful emotional events like accidents, examinations, sexual assaults or death of relatives have also been related to the onset of the disease. Moreover, a correlation between high stressed group and psoriasis area and severity index (PASI) score has also been established $(8,9)$. Physical trauma including cuts, scarring, sunburn and Koebner response may also lead to the induction of psoriasis $(10,11)$. Lifestyle could play a role in modifying psoriasis pathogenesis. Among these factors diet (polyunsaturated fatty acids, gluten and alcohol), smoking and ultraviolet radiation are suspected (12-15). 
Several studies focused mainly on the lesional skin and as a result of these efforts now it is well characterized that psoriasis is a chronic, inflammatory skin disease in which both innate and adaptive immune activation play a role in the manifestation and the maintenance of the abnormal skin phenotype (16). However, much less is known about the contribution of resident cells of the tissue to the pathology of the disease. Therefore, we focused on to seek for alterations in tissue responses in psoriasis by investigating the phenotypically normal looking non-lesional (NL) psoriatic skin.

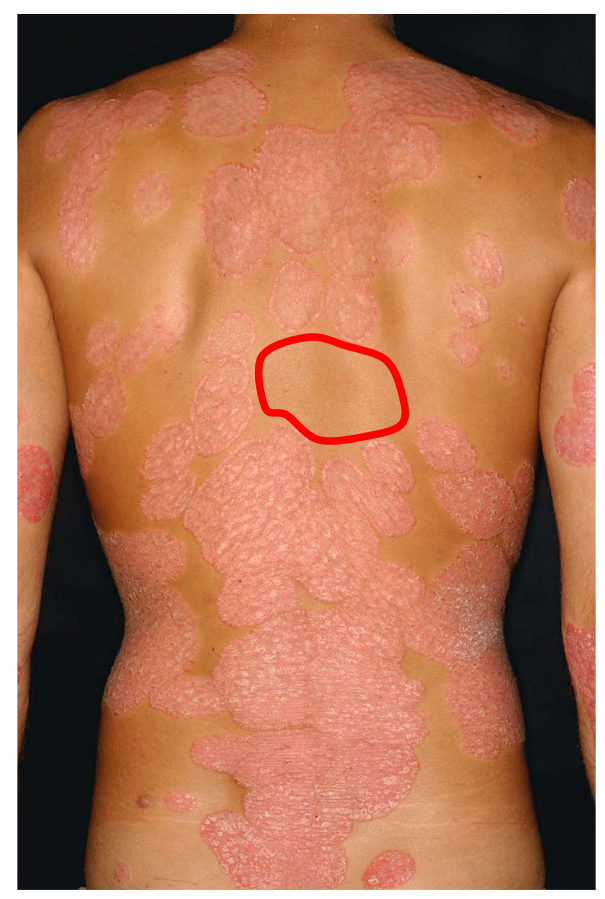

Figure 1. Non-lesional (NL) and lesional (L) psoriatic skin. Psoriatic lesional skin manifests as raised, red scaly and well- demarcated plaques. Non-lesional skin is marked with red. The picture is from the clinical archive of the Department of Dermatology and Allergology, University of Szeged. 


\subsection{Structure and function of fibronectin}

\subsubsection{The role of fibronectin-binding integrins}

Integrins are cell-surface heterodimeric transmembrane receptors consisting of an $\alpha$ and a $\beta$ subunit. Integrins are known to play essential roles in connecting the intracellular cytoskeleton with various components of the extracellular matrix (ECM). Through these interactions integrins transduce mechanical and chemical information from the extracellular space into the intracellular environment and regulate specific signal transduction cascades. Fibronectin (FN) is a protein secreted as a soluble dimer and through interactions with integrins they form fibrillar structures. The main FN receptor $\alpha_{5} \beta_{1}$ integrin was found to be overexpressed in the NL psoriatic epidermis relative to normal $(17,18)$. There is evidence that the proper regulation of integrin expression in keratinocytes is essential for normal epidermal homeostasis as shown by the suprabasal overexpression of integrins in transgenic mice resulting in epidermal hyperproliferation and inflammatory reaction (19).

In the steady state of normal human adult epidermis $\alpha_{5}$ integrin expression of keratinocytes is downregulated. A possible explanation of $\alpha_{5}$ integrin overexpression in NL skin is the presence of FN and one of its isoforms, the extra-domain-A containing fibronectin $\left(\mathrm{EDA}^{+} \mathrm{FN}\right)$ in the microenvironment of basal keratinocytes $(18,20)$. The $\mathrm{EDA}^{+}$domain contains an additional non-classical (non-RGD) binding site (EDGIHEL) for $\alpha_{4} \beta_{1}, \alpha_{9} \beta_{1}$ and $\alpha_{4} \beta_{7}$ integrins (Figure 2) (21). $\alpha_{4} \beta_{1}$ integrin conveys the EDA-induced stress fibers, myosin light chain phosphorylation, fibrillogenesis, fibronectin synthesis and deposition (22). 


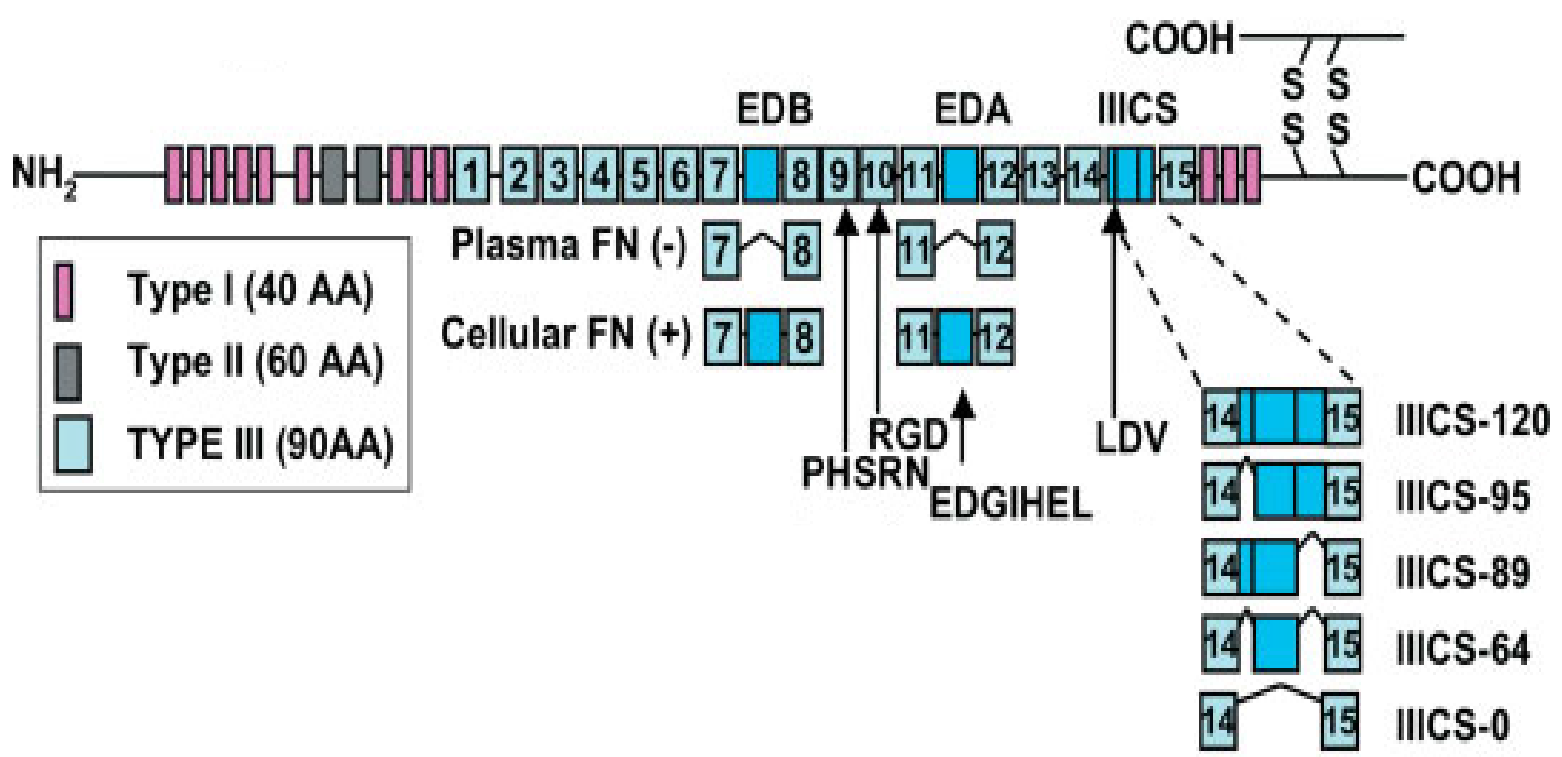

Figure 2. Schematic domain structure of fibronectin and positions of binding sites of interaction partners. The different types of homologous domains (12 Type I, two Type II and 15 Type III) are represented. Conservative (RGD) and alternatively spliced (LDV), synergy (PHSRN) and EDA (EDGIHEL) binding sites are indicated, together with their integrin receptor partners. EDA and EDB splicing is similar in all species, while that of the IIICS region is species-specific (five variants in humans, three in rodents and two in chickens) (21). (Modified figure based on the publication of White et al., 2008.)

\subsubsection{Structure and function of $\operatorname{EDA}^{+} \mathrm{FN}$ and $\mathrm{FN}$}

FN is a multifunctional component of the ECM. FN filaments interact with other ECM components including fibrin, fibulin-1, heparin, syndecans, cartilage oligomeric matrix protein (COMP) (23) and collagens (24). Matrix FN provide a base to the cells and regulate the cellular behavior through the transfer of biochemical and mechanical signals. There are two major distinct forms of FN: the plasma and the cellular FN. The secondary structure of FN consist of the following domains: type I, II and III repeats (Figure 2). Type I and II domains are stabilized by disulphide bonds in contrast to the type III domains that consist of seven anti-parallel betastrand which are arranged into two distinct beta-sheets $(25,26)$. FN could contain one or two extra Type III domains, named $\underline{E} x \operatorname{tra} \underline{D}$ omain $\underline{A}$ and $\underline{B}$ (EDA and EDB, respectively). These two domains could be inserted/excluded through alternative splicing (21). The alternatively spliced ED sequences are lacking from the plasma FN secreted mostly by hepatocytes. In contrast, the cellular form of FN contains the EDA domain and found incorporated into the 
ECM of tissues. Several stromal cell types are able to produce cellular fibronectin but the main source of this protein are the fibroblasts. The alternative splicing of $\mathrm{FN}$ is regulated by splicing regulator (SR) proteins. The regulatory sequence of EDA is a purin-rich region found within the exon itself (27) and is recognized by splicing factor 2 (SF2) /alternative splicing factor (ASF) (28).

The production of alternatively spliced forms is the highest during embryonic development. Postnatal the amount of the protein is reduced and further decreases with ageing (21). However, elevated amount of the $\mathrm{EDA}^{+} \mathrm{FN}$ is observed during tissue repair, wound healing, angiogenesis and in highly proliferating adult tissues, it can influence cell adhesion, differentiation, cell cycle progression (29-31). The EDA ${ }^{+} \mathrm{FN}$ is appearing at the basement membrane of NL epidermis compared to normal skin $(20,32)$. TGF $\beta 1$ is known to enhance $\mathrm{EDA}^{+} \mathrm{FN}$ production in wounded tissues (33). Moreover, $\mathrm{EDA}^{+} \mathrm{FN}$ can modulate matrix remodelling by the regulation of cytokine-dependent matrix metalloproteinases (34). EDA ${ }^{+} \mathrm{FN}$ can activate matrix metalloproteinase 9 (MMP9) and NF- $\kappa B$ production via Toll-like receptor 4 (TLR4) thereby contributing to the manifestation of inflammatory responses (30). In human dermal fibroblasts $\mathrm{EDA}^{+} \mathrm{FN}$ was described to stimulate the expression of pro-inflammatory cytokines including CXCL1-3 (35) and to induce interleukin 8 (IL-8) expression through NF$\kappa \mathrm{B}$ and $\mathrm{p} 38 / \mathrm{MK}-2$ signaling cascade (36).

\subsection{The role of $\mathrm{KGF}$ in health and disease}

\subsubsection{Structure and function of KGF}

Fibroblast growth factors (FGFs) are small growth factor polypeptides (37). The family of FGF consists of 23 members with a common structural characteristic, although there are only 18 FGFs that are known to serve as a ligand for the four different FGF receptors (38). Most FGFs have an autocrine and/or paracrine function. Fibroblast growth factor 7 (FGF7), also known as keratinocyte growth factor (KGF) is produced by cells of mesenchymal origin and considered to be a major growth factor for keratinocytes. KGF was first isolated by Rubin and colleagues and characterized as a fibroblast produced growth factor of keratinocytes (39). In the skin KGF is produced by dermal fibroblasts and keratinocytes can influence its production through interleukin 1 (IL-1). 
KGF is known to induce keratinocyte proliferation and differentiation. Several reports suggest that KGF reduces the ability of keratinocytes to initiate terminal differentiation and undergo programmed cell death. Overexpression of KGF in the basal epidermal cell layer of transgenic mice results in epidermal hyperplasia (40). There is also evidence suggesting that fibroblasts from $L$ and NL skin of psoriatic patients induce keratinocyte outgrowth by producing soluble signals (41). More recently, it has been reported that KGF can induce the expression of $\alpha_{5}$ integrin and delays the expression of keratin 10 and transglutaminase in keratinocytes (42). Indirect evidence, such as measurement of mitogenic activity, suggests that the specific receptor for KGF on epithelial cells is the IIIb splice variant of fibroblast growth factor receptor 2 (FGFR2) (43).

\subsubsection{Structure and isoforms of FGFR2}

The FGFR family consist of FGFR1, FGFR2, FGFR3 and FGFR4 encoding for receptors of FGFs. FGFRs are transmembrane-type receptors, composed of an extracellular ligand-binding domain, a single transmembrane domain and a cytoplasmic domain. The cytoplasmic domain of FGFRs contains the catalytic protein tyrosine kinase core and regulatory sequences (44). FGFRs are formed in two different ways: by the expression of different splice variants of the same FGFR gene that can form homo- or heterodimers or by the expression of two different FGFR genes that go under hetero-dimerization following ligand binding (39). Alternative splicing in the third immunoglobulin (Ig)-like domain provides increased ligand specificity for different members of the FGFR family $(38,45,46)$. The extracellular ligand binding domain of FGFRs consists of either two or three Ig-like domains. Alternative RNA splicing is realized by utilizing one of the two unique Ig-like exons in designated as IIIb and IIIc versions in FGFR1, 2 and 3, with the exception of FGFR4 where no alternative splicing take place (43). FGFR2 has two isoforms FGFR2-IIIb and FGFR2-IIIc. The expression of the different isoforms of FGFR2 is regulated in tissue-specific manner, where isoform IIIb is mainly produced by epithelial cells and the isoform IIIc by mesenchymal cells (47). KGF is known to initiate mitogenic activity most effectively by binding to the FGFR2-IIIb splice variant. KGF can also facilitate cell proliferation through FGFR2-IIIc or FGFR1, but with a much lower efficiency (37). The schematic structure of FGF-FGFR and the formation of the two different FGFR isoforms by splicing are shown in Figure 3. 
a

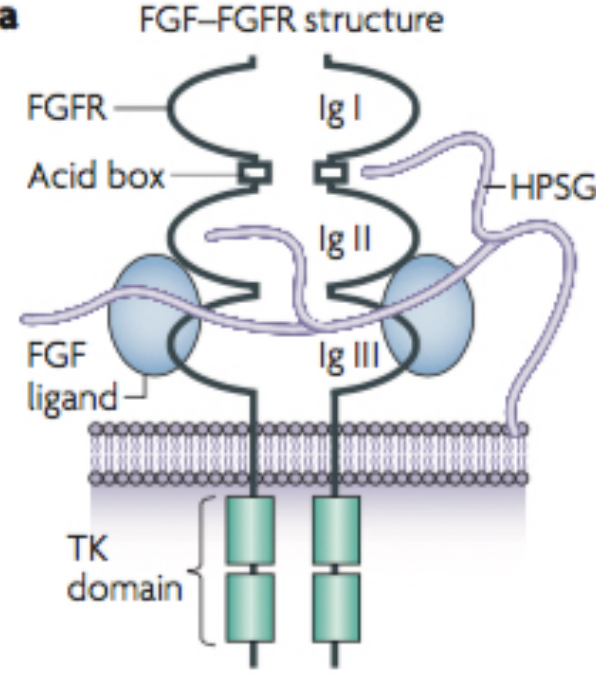

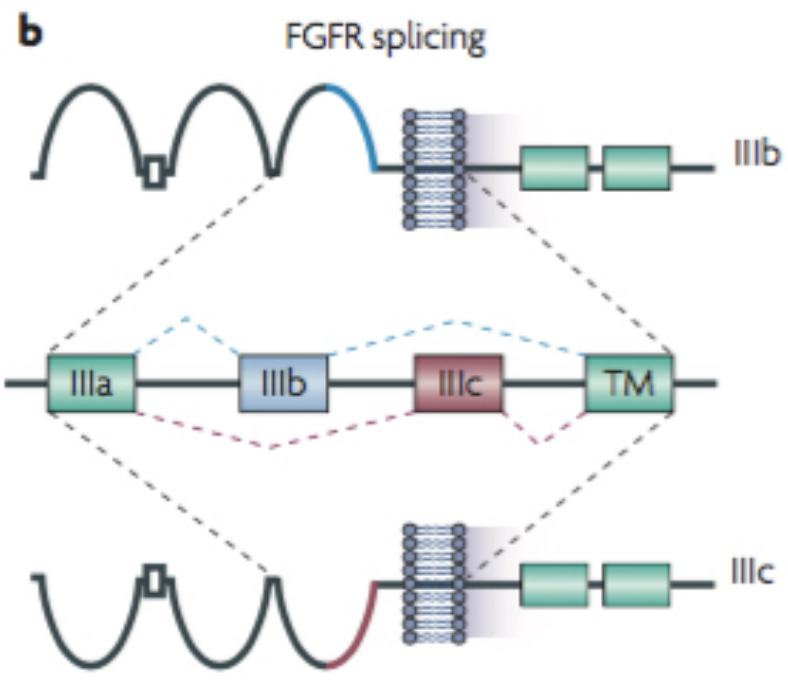

Figure 3. FGF-FGFR structure and FGFR splicing. a The basic structure of the FGF-FGFR complex comprises two receptor molecules, two FGFs and one heparan sulphate proteoglycan (HSPG) chain. FGFs bind with low affinity to cell surface HSPGs (purple) and with high affinity to specific FGFRs. The FGFRs consist of three extracellular immunoglobulin (Ig) domains, a single transmembrane helix and an intracellular split tyrosine kinase (TK) domain. The second and third Ig domains form the ligand-binding pocket and have distinct domains that bind both FGFs and HSPGs. b Ligand-binding specificity is generated by alternative splicing of the Ig III domain. The first half of Ig III is encoded by an invariant exon (IIIa), which is spliced to either exon IIIb or IIIc, both of which are spliced to the exon that encodes the transmembrane (48) region. Epithelial tissues predominantly express the $\mathrm{IIIb}$ isoform and mesenchymal tissues express IIIc. FGFR4 is the only member of the FGFR family that is expressed as a single isoform (38). (Modified figure based on the publication of Turner et al., 2010.)

\subsubsection{FGF and FGFR signaling network}

FGFs transmit their signal through binding to specific FGFRs. FGFs are secreted glycoproteins that are localized to the extracellular matrix and to the cell surface by heparin sulphate proteoglycans (HPSGs) (49). FGFs are released from the extracellular matrix by heparinases, proteases or specific FGF binding proteins and are associated with HPSGs on the cell surface, where they induce the dimerization and autophosphorylation of FGFRs (44). The specificity of FGF-FGFR interaction depends on the alternative splicing of FGFR. FGFs create a ternary complex with respective FGFRs and HPSGs (Figure 4). Following ligand binding FGFR monomers undergo dimerization forming homo- or heterodimers (39). Dimerization leads to conformational change in the receptor triggering the autophosphorylation of the intracellular tail. Phosphorylated tyrosine residues are binding sites to the signal transduction proteins, resulting in the induction or modulation of the four distinct signalling cascades: 
phospholipase $\mathrm{C} \gamma$ (PLC $\gamma$ ), mitogen activated protein kinase (RAS-RAF-MAPK), phosphoinositide-3 kinase (PI3K)- v-akt murine thymoma viral oncogene homolog (AKT) and signal transducer and activator of transcription (STAT) $(38,50)$.

Activated FGFR2 phosphorylates the FGFR substrate 2 (FRS2) to recruit the son of sevenless and growth factor receptor-bound protein 2 (GRB2) leading to the activation of the RAS-RAF-MEK-MAPK/ERK pathway. AKT-dependent anti-apoptotic signalling cascade is activated by GRB2-associated binding protein 1- PI3K (GAB1-PI3K) in a separate complex. On the other hand, the Src homology 2 (SH2) domain of PLC $\gamma$ binds and activate the protein kinase C (PKC), which reinforces the activation of MAPK. Finally, the activation of the STAT pathway depends on cellular context (Figure 4).

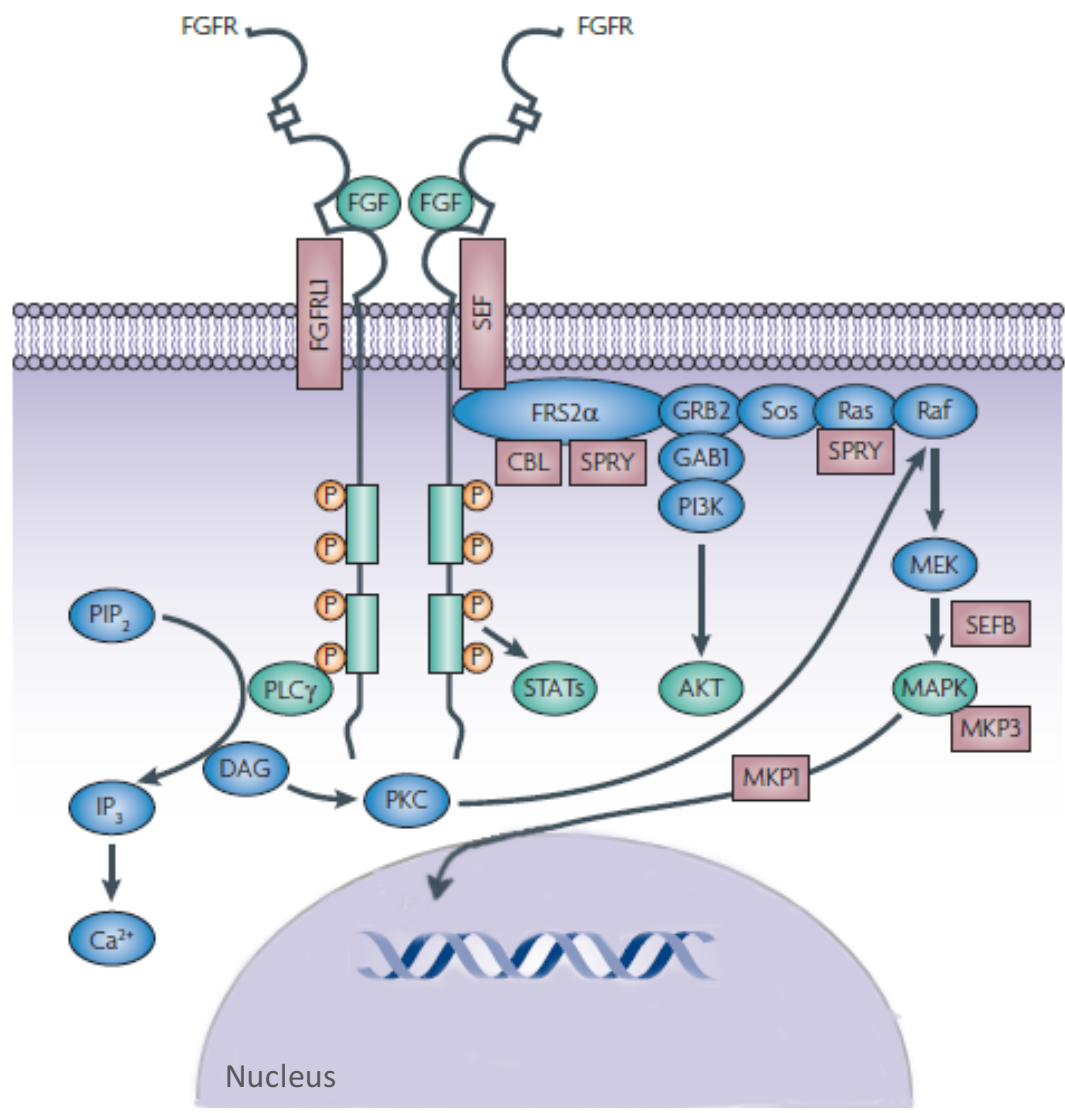

Figure 4. FGF-FGFR signalling network. Following ligand binding and receptor dimerization, the kinase domains transphosphorylate each other, leading to the docking of adaptor proteins and the activation of four key downstream pathways: RAS-RAF-MAPK, PI3K-AKT, signal transducer and activator of transcription (STAT) and phospholipase $\mathrm{C} \gamma$ (PLC $\gamma$ ) (green) (38). (Modified figure based on the publication of Turner et al., 2010.) 


\subsubsection{Autocrine and paracrine signaling roles of KGF and FGFR2 in pathophysiology and therapy}

There are several pieces of evidence highlighting the important function of KGF in the processes of wound healing, tissue regeneration and repair. KGF released by stromal cells enrols the appropiate receptor of target epithelial cells thus form paracrine stimuli facilitating epithelial regeneration. The paracrine signaling functions of KGF are explored for their therapeutic potential in mucositis and wound healing (51). Recombinant produced human KGF, Palifermin is already in use to treat mucositis after chemotherapy and radiotherapy (52). Furthermore, KGF can modify the extent of ureteric bud growth during development and the number of nephrons in the kidney (53) and accelerate the repair of renal tubules after chemically induced proximal tubule damage (54).

Genetic alterations of FGFR2 that cause dysregulation of FGFR2 signaling can lead to the development of congenital disorders and acquired diseases including melanoma, Apert syndrome and atopic dermatitis among others (55). FGFR2-IIIb knockout mice die after birth due to multiple organ abnormalities including dysgenesis of the skin and agenesis of the lungs and limbs (56). Amino-acid substitutions around the third immunoglobulin-like domain of FGFR2 lead to the alteration of ligand selectivity among different FGFs (57), whereas mutations within the tyrosine kinase domain cause autoactivation of the receptor independently from ligand binding $(58,59)$. The FGFR2 gene is mutated in Apert syndrome, where ligand specificity experiments showed that the mesenchymally expressed FGF7 is able to bind thereby to activate the mesenchymal splice form of FGFR2 (FGFR2-IIIc) (57). Furthermore, genetic alterations in FGFR2 give rise to skin manifestations like melanoma, squamous cell carcinoma and basal cell carcinoma (59). 


\subsection{The JAK-STAT signaling pathway}

\subsubsection{The role of the JAK-STAT signaling pathway in inflammation and immunity}

The Janus kinase (JAK)-STAT pathway plays an important role in both innate and adaptive immunity and contributes to the manifestation of several inflammatory processes. In mammals the JAK family consists of four tyrosine kinases: JAK1, JAK2, JAK3 and TYK2, while the STAT family has seven members: STAT1, STAT2, STAT3, STAT4, STAT5a, STAT5b and STAT6. STAT proteins share a similar structural composition: N-terminal domain, coiled-coil domain, DNA binding domain, linking domain, $\mathrm{SH} 2$ domain and transcriptional activation domain.

JAK-STAT is activated by over 50 cytokines and growth factors, these cytokines include interferons, colony stimulating factors, several interleukins and hormones $(60,61)$. Extracellular cytokines or growth factors associate with their corresponding cell surface type I and type II cytokine receptors, ligand binding leads to conformational change and dimerization of the receptor allowing the binding of JAK pairs in the cytoplasm (62). Dimerized JAKs autophosphorilate and become activated enabling STAT binding and phosphorylation. Phosphorylated STAT monomers form dimers that are translocated into the nucleus of the cell and influence transcription of several genes (Figure 5) (63).

The IFN $\gamma$-induced route of STAT1 has been well characterized. The regulation of STAT1 signaling by IFN $\gamma$ takes place via the modulation JAK1 and JAK2 phosphorilation. Furthermore IFN $\gamma$ activates transcription factors called interferon regulatory factors (IRF) IRF1 and IRF8 via STAT1 (64). IRFs such as IRF1, IRF3, IRF5, IRF7 and IRF8 contribute to the TLR mediated signaling through the critical mediator STAT1 $(65,66)$. In a TLR4- dependent manner STAT1 phosphorylation can increase the expression of inflammatory mediators such as chemokine $\mathrm{C}-\mathrm{X}-\mathrm{C}$ motif chemokine 10 (CXCL10) and the adhesion molecule ICAM1 by IFN $\gamma$ and LPS cross-talk (66). Moreover, IRF8 in association with IFN $\gamma$ and LPS mediate the transcriptional activation of chemokine RANTES (CCL5) (67) leading to attraction of leukocytes to the site of injury of tissues including that of arteries. IFN $\gamma$ and LPS coadministration triggers macrophage STAT1 pool super-activation and IRF8 expression $(68,69)$. The newly synthetized IRF8 enhances the crosstalk between IFN $\gamma$ and TLR inducing further 
activation of STAT1 as well as inflammatory molecules and thereby contributing to antimicrobial defense (64).

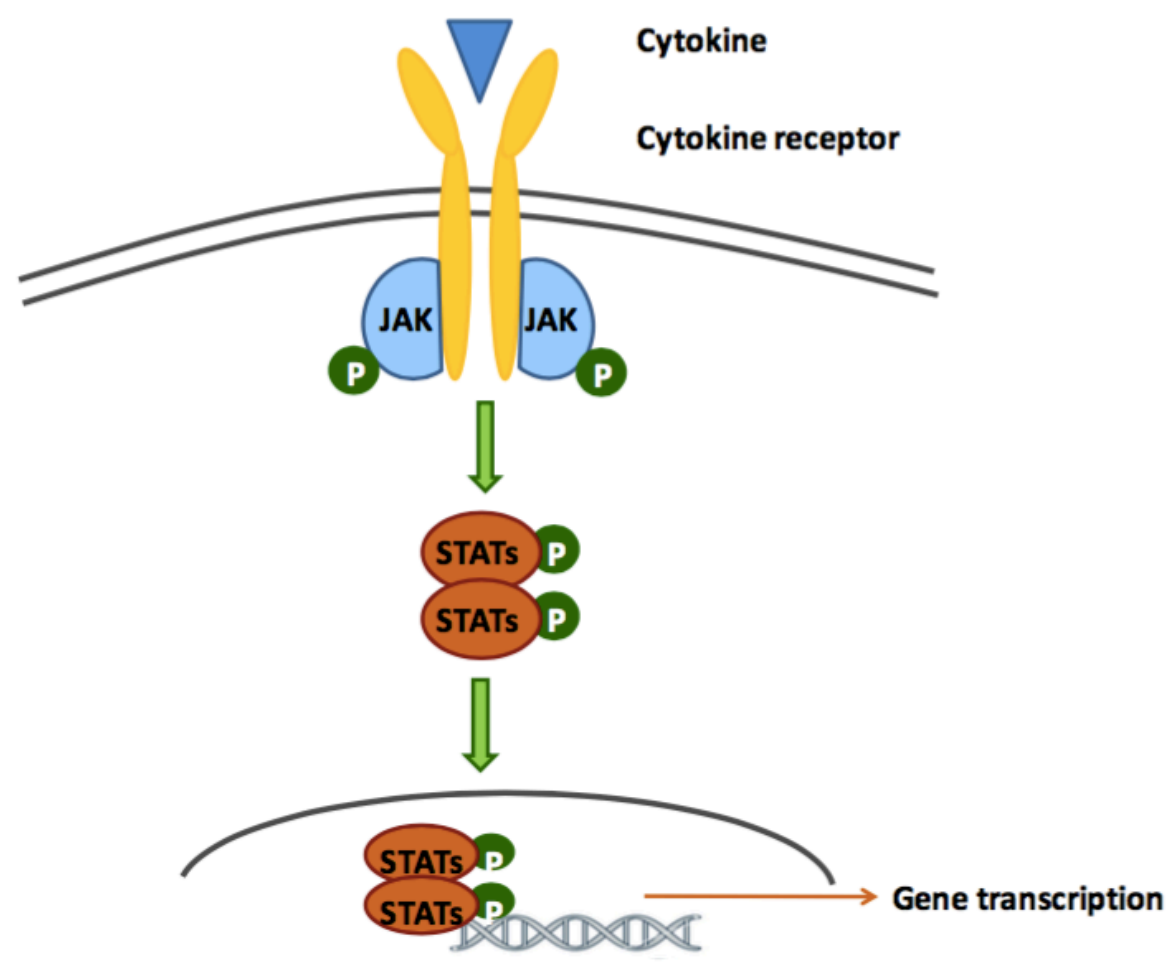

Figure 5. The schematic illustration of JAK-STAT signaling. (JAK: Janus kinase; STAT: signal transducer and activator of transcription; P: phosphorylation)

\subsubsection{Disruption of STAT1 signaling in human diseases}

Several studies revealed alterations in the JAK-STAT signaling in chronic skin diseases including psoriasis, atopic dermatitis and melanoma. STAT1 was observed to be localized predominantly in the horny layer in normal skin by immunostaining (70). Impaired phosphorylation of STAT1 and STAT5 was described to cause defective response to IL-2 in melanoma from stage III to IV (71). STAT1 in tumors functions as a suppressor probably by mediating the TNF $\alpha$ triggered apoptotic program (72).

Both loss-of-function and gain-of-function mutations were found in genes coding STAT transcription factors. Strikingly, all of the known STAT1 mutations are coupled with a particular type of pathogen. Patients with STAT1 loss-of-function mutations are more prone to mycobacterial and viral infections, whereas gain-of-function mutations increase susceptibility to fungal infections $(73,74)$. 


\section{AIMS}

The pathogenesis of psoriasis is still not fully understood, numerous studies have proposed hypotheses regarding to immune dysregulations (3), skin microbiota system (75) or extracellular matrix alterations (76) among others to play essential roles in the development of the disease. A continuously growing body of evidence indicate that the healthy looking NL psoriatic skin represents an unbalanced phenotype and carries structural alterations compared to normal skin making it susceptible for developing the disease. Abnormalities of the basement membrane at the dermal-epidermal junction (DEJ) render the uninvolved skin to become activated and present a chronic wound healing phenotype.

FN is capable to enhance cell cycle entry, without the increase of adhesion, in uninvolved, but not normal keratinocytes, even in the absence of $\mathrm{T}$ cell lymphokines (77). The main FN receptor $\alpha 5 \beta 1$ integrin was found to be overexpressed in NL psoriatic epidermis relative to normal epidermis $(17,18)$. KGF together with fibronectin and $\alpha 5 \beta 1$ integrin was suggested to play a crucial role in the pathogenesis of psoriasis by influencing inflammation and keratinocyte hyperproliferation. We focus in particular on alterations in NL skin and the role of $\mathrm{EDA}^{+} \mathrm{FN}$ and KGF in the initiation and progression of psoriasis.

Therefore, we aimed:

- To investigate the expression of KGF, FGFR2, $\mathrm{EDA}^{+} \mathrm{FN}$ and $\alpha 5$ integrin in healthy and NL psoriatic skin.

- To examine whether KGF has an effect on the $\mathrm{EDA}^{+} \mathrm{FN}$ and $\mathrm{FN}$ production in cultured fibroblasts, keratinocytes and $\mathrm{HaCaT}$ cells.

- To determine the expression of different splice forms of FGFR2 in fibroblasts, keratinocytes and melanocytes.

- To identify the signal transduction pathway(s) through which KGF may influence and modulate the expression of $\mathrm{EDA}^{+} \mathrm{FN}$ and FN in healthy and NL skin derived fibroblasts.

- To study the putative correlation between the activation of STAT1 in healthy, NL and L skin and PASI score of patients.

- To construct an in silico model based on transcriptional regulatory molecules combined with our in vitro results involving KGF and FN signaling. 


\section{MATERIALS AND METHODS}

\subsection{Skin biopsies}

Patients with moderate-to-severe chronic plaque type psoriasis and healthy volunteers (age 18-60 years) were enrolled into the study. Patients had a medication-free period of at least 4 weeks of systemic and/or at least 2 weeks without local therapy. Participant informed consent was obtained prior surgical intervention. PASI score was determined for all patients by dermatologists. Samples were collected from 16 patients and 25 healthy volunteers for the experiments. Mechanical stress was induced by tape-stripping procedure, and then punch biopsies were taken from uninvolved skin of psoriatic patients $(n=6)$ and from healthy $(n=6)$ subjects from tape-stripped and non-treated skin area from the buttock area at 24 and 48 hours after treatment for all other experiments tissues without the introduction of mechanical stress were used. All tissue collection complied with the Guidelines of the Helsinki Declaration and was approved by the Regional and Institutional Research Ethics Committee (Approval No:2799, 3517).

\subsection{Cell culture}

Primary keratinocytes, melanocytes and fibroblasts were obtained from healthy participants or psoriatic patients by enzymatic digestion of skin biopsies according to a standard protocol. Briefly, skin specimens were first washed in Salsol A solution (Human Rt, Gödöllö, Hungary) supplemented with 2\% antibiotic/antimycotic solution (Sigma-Aldrich). Skin samples were then cut into narrow strips and incubated in Dispase solution (Roche Diagnostics, Mannheim, Germany) overnight at $4{ }^{\circ} \mathrm{C}$. The epidermis was subsequently separated from the dermis and incubated in $0.25 \%$ trypsin $/ 0.02 \%$ EDTA (PAA, Pasching, Austria) for 5 min at $37^{\circ} \mathrm{C}$ to achieve a single-cell epidermal suspension. Fibroblasts were obtained by incubating the dermis in Digestion Mix (27mg Collagenase, 12.5mg Hyaluronidase and $1 \mathrm{mg}$ Deoxyribonuclease/ $10 \mathrm{ml}$ DMEM medium) for $2 \mathrm{~h}$ at $37^{\circ} \mathrm{C}$. The cell suspensions were filtered through a $100 \mu \mathrm{m}$ nylon mesh (BD Falcon, San Jose, CA, USA) and pelleted by centrifugation.

Fibroblasts were grown in low glucose DMEM medium containing 5\% FBS. Melanocytes were maintained in Mel-mix medium as previously described (78). Keratinocytes 
were grown in keratinocyte serum-free medium (Gibco ${ }^{\circledR}$ Keratinocyte SFM Kit; Life Technologies, Copenhagen, Denmark). HaCaT cells were kindly provided by Prof N.E. Fusenig and cultured in high-glucose DMEM medium containing 10\% FBS. All media was supplemented with 1\% antibiotic/antimycotic (PAA) and 1\% L-glutamine solution (PAA). Fibroblasts, keratinocytes, melanocytes, and $\mathrm{HaCaT}$ cells were cultured at $37^{\circ} \mathrm{C}$ and $5 \% \mathrm{CO}_{2}$ in humidified conditions. Depending on cell growth, the medium was changed every 2-4 days and cells were passaged at $80 \%$ confluence. In our experiments, fibroblasts at passage number 5 , keratinocytes and melanocytes at passage 3 were used at $70 \%$ confluence.

Fibroblasts, keratinocytes and $\mathrm{HaCaT}$ cells were cultured in 6-well plates at a starting density of 200,000 cells/well and incubated with 25 ng/mL KGF (ProSpec -Tany TechnoGene Ltd., Rehovot, Israel) for $24 \mathrm{~h}$; untreated cells were used as controls. For KGF signaling pathway blocking experiments the following inhibitors were used: MEK1 inhibitor (PD98059, $20 \mu \mathrm{M})$, AKT $1 / 2$ kinase inhibitor $(10 \mu \mathrm{M})$, STAT1 inhibitor (Epigallocatechin gallate, $40 \mu \mathrm{M}$ ) and STAT3 inhibitor (Stattic, $4 \mu \mathrm{M}$ ), all provided by Sigma-Aldrich, concentrations were applied as previously described (79-81). The pictures were taken using a Nikon Eclipse TS100 inverted microscope (Nikon Incorporation, Melville, USA).

\subsection{RNA extraction and real-time quantitative reverse transcription polymerase chain reaction ( $R T$ qRT-PCR)}

For RNA isolation fibroblasts, melanocytes and keratinocytes were cultured as described above. Cells on 6 well plates were washed once with PBS, then harvested with 0.5 ml TRIzol ${ }^{\mathrm{TM}}$ Reagent (Life Technologies). Total RNA was isolated according to the manufacturer`s instructions. RNA concentration was determined from A260 values. All RNA was treated with DNA-free ${ }^{\mathrm{TM}}$ reagents (Life Technologies). cDNA was synthesized from $1 \mu \mathrm{g}$ total RNA with the iScript cDNA Synthesis Kit (Bio-Rad Laboratories, Hercules, CA, USA) according to the manufacturer's protocol.

For $\mathrm{EDA}^{+} \mathrm{FN}$ qPCR amplification $\mathrm{iQ}^{\mathrm{TM}}$ Supermix (from Bio-Rad Laboratories Hercules, CA, USA) was used. The EDA ${ }^{+} \mathrm{FN}$ primers were constructed as described previously (82). The amplification protocol for $\mathrm{EDA}^{+} \mathrm{FN}$ qPCR was the following: $95^{\circ} \mathrm{C}$ for $3 \mathrm{~min}$, and then $95^{\circ} \mathrm{C}$ for $15 \mathrm{~s}$ and $56^{\circ} \mathrm{C}$ for $30 \mathrm{~s}$, repeated 40 times. 
FN and 18S rRNA amplifications were carried out with FastStart TaqMan Probe Mastermix (Roche Basel, Switzerland) using the following primers: FN forward 5'GGAAAGTGTCCCTATCTCTGATACC-3', reverse 5'-AATGTTGGTGAATCGCAGGT3', probe: \#33. 18S RNA forward 5'-CTCAACACGGGAAACCTCAC-3', reverse 5'CGCTCCACCAACTAAGAACG-3', probe: \#77 (probes were from the Roche Universal Probe Library). Primers were designed using Probefinder for the Universal Probe Library system (Roche Diagnostics, Basel, Switzerland). FN and 18S rRNA amplifications were carried out under the following conditions: $95^{\circ} \mathrm{C}$ for $3 \mathrm{~min}$, and then $95^{\circ} \mathrm{C}$ for $15 \mathrm{~s}$ and $57^{\circ} \mathrm{C}$ for $1 \mathrm{~min}$, repeated 40 times.

For FGFR2-IIIb and FGFR2-IIIc, specific custom TaqMan primer/probe sets (Life Technologies, Carlsbad, CA, USA) were developed as described previously (83) and for amplification the following protocol was used: $95^{\circ} \mathrm{C}$ for $10 \mathrm{~min}$, and then $95^{\circ} \mathrm{C}$ for $15 \mathrm{~s}$ and $60^{\circ} \mathrm{C}$ for $1 \mathrm{~min}$, repeated 40 times.

RT-PCR experiments were carried out on the LightCycler ${ }^{\circledR} 480$ System Real-Time PCR machine (Roche Cobas Z 480 Roche Diagnostics). The abundance of each gene products was normalized to the $18 \mathrm{~S}$ rRNA gene expression in each examined sample. Relative mRNA levels were calculated by the $2^{-\Delta \Delta \mathrm{Ct}}$ method. Data are expressed as arbitrary units proportional to the mRNA level.

\subsection{Immunofluorescent and immunohistochemistry staining}

Human punch biopsies were frozen embedded, stored at $-80{ }^{\circ} \mathrm{C}$, then cut into $6 \mu \mathrm{m}$ sections. Samples were fixed in Fixation/Permeabilization Concentrate and Diluent (eBioscience, San Diego, CA) and washed in PBS. The sections were incubated for $30 \mathrm{~min}$ in $1 \%$ goat serum in PBS (Sigma-Aldrich, St. Louis, MO, USA). The following primary antibodies were used: FGFR2 (1:100, Bek (C-17), Santa Cruz Biotechnology, Santa Cruz, CA), KGF (1:500, FGF-7 (N-14), Santa Cruz Biotechnology), $\alpha_{5}$ integrin (1:200, Becton-Dickinson, Franklin Lakes, NJ, USA), $\operatorname{EDA}^{+} \mathrm{FN}$ (1:500, clone IST9, Abcam, Cambridge, UK), and pSTAT1(Ser727), pSTAT1 (Tyr701), (both 1:400, Cell Signaling Technology, Beverly, MA) overnight at $4^{\circ} \mathrm{C}$. Goat anti-rabbit IgG-Alexa Fluor 488, donkey anti-goat IgG-Alexa Fluor 546, goat anti-mouse IgG-Alexa Fluor 647 and Alexa Fluor 546 were used as secondary antibodies (all 1:500, from Life Technologies, Carlsbad, CA) for $2 \mathrm{~h}$, at room temperature. Sections were 
incubated without the primary antibody or with isotype control antibody for negative staining controls. Nuclei were stained with DAPI (Sigma-Aldrich).

For immunohistochemistry paraffin embedded section of the three different skin types (mentioned above) were applied at $5 \mu \mathrm{m}$ thickness and the $\mathrm{ABC}$ kit for the appropriate primary antibody (Enzo Life Sciences Inc.) was used according to the guidelines of the manufacturer to develop immunostaining. The counterstain of the cytoplasm and the nuclei was achieved by applying haematoxylin staining.

Cultured human fibroblasts, keratinocytes and HaCaT cells were collected after brief trypsinization ( $0.25 \%$ trypsin solution, Sigma Aldrich) and centrifuged onto a slide using a cytocentrifuge Cytopro $^{\mathrm{TM}}$, Wescor, Logan, UT, USA), then fixed in 2\% paraformaldehyde (Sigma-Aldrich). Stainings were carried out, as described above. Images were documented with a Zeiss AxioImager Z1 fluorescence microscope (Carl Zeiss Microscopy GmbH, Munich, Germany) equipped with an AxioCam MRm camera and AxioCam MRc camera for transmission light (bright field). Image processing and data analysis were conducted using ZEN 2012 Microscope and Imaging or ImageJ software.

\subsection{Flow cytometry}

Cells were harvested as described, above fixed in Fixation/Permeabilization Concentrate and Diluent (eBioscience) and resuspended in PBS. Primary antibodies antiEDA $^{+}$FN (1:500, clone IST9, Abcam), anti-FN (1:1000, clone IST4, Sigma-Aldrich) were applied for $45 \mathrm{~min}$. Mouse IgG1 isotype antibody (Sigma-Aldrich) was used, for negative as control. Cells were then washed in PBS, and incubated with secondary antibodies as described above. Samples were analysed on a FACS Calibur flow cytometer equipped with 488 and 633 nm lasers (Becton-Dickinson). Data was analysed using CellQuest Pro.

\subsection{Statistical analysis}

For statistical analysis, Repeated Measures Friedman ANOVA, Wilcoxon or one-way ANOVA were used. Multiple comparisons were done with SigmaPlot software (Systat Software Inc., Chicago, IL, USA). A probability test was used to test for normality, $\mathrm{P} \leq 0.05$ was considered significant. 


\subsection{Bioinformatics analysis and model construction}

STRING, KEGG database and Reactome were used as a source to create protein-protein interactions and signaling pathways; SABiosciences' transcription factor binding site data and CisRED $(p<0.001)$ were applied for modeling protein-DNA interactions. Direction of transcriptional regulation was assessed with expression correlation matrix. Data of a microarray study with 48 dermal fibroblast samples carried out by Gabig-Cimińska et al. was downloaded from Gene Expression Omnibus. Probe with the largest interquartile range (IQR) was selected for genes with multiple probes. Coexpressional matrix was constructed using MATLAB R2014b (MathWorks Inc., Natick, MA). The genes and proteins related to KGF signaling, fibronectin-signaling, splicing and the regulation of these genes were collected (summarized in Table 1) and used for filtered matrix construction (Table 2). We used Pearson correlation coefficients with $\mathrm{p}$ values under 0.05 for the assessment of the direction of transcriptional regulation. If the correlation coefficient was positive it was considered an upregulation, and if it was negative, down regulation was defined.

\begin{tabular}{|l|l|l|l|}
\hline TARGET GENES & \multicolumn{3}{|c|}{ TRANSCRIPTION FACTORS } \\
\hline STAT1 & STAT5b & AP-1 & \\
\hline STAT3 & & & \\
\hline STAT5a & AP-1 & & \\
\hline STAT5b & AP-1 & & \\
\hline FN & STAT3 & AP-1 & \\
\hline FGF7 & STAT3 & AP-1 & \\
\hline FGFR2 & AP-1 & SOX9 & \\
\hline MAP2K1 & STAT3 & & \\
\hline AKT1 & & & \\
\hline AKT2 & AP-1 & STAT3 & \\
\hline AKT3 & & & \\
\hline ITGA5 & AP-1 & & \\
\hline FOXO1 & AP-1 & & \\
\hline FOS & STAT1 & & \\
\hline FOSb & & & \\
\hline JUN & STAT5a & & \\
\hline JUNb & AP-1 & & \\
\hline JUNd & & & \\
\hline JDP2 & & & \\
\hline ATF1 & ATF2 & & \\
\hline ATF2 & ATF2 & & \\
\hline ATF3 & AP-1 & & \\
\hline ATF4 & AP-1 & ATF2 & ATF6 \\
\hline ATF5 & & & \\
\hline ATF6 & ATF6 & & \\
\hline ATF6b & & & \\
\hline ATF7 & & & \\
\hline
\end{tabular}

Table 1. List of genes applied for the construction of the co-expression matrix gene model. 


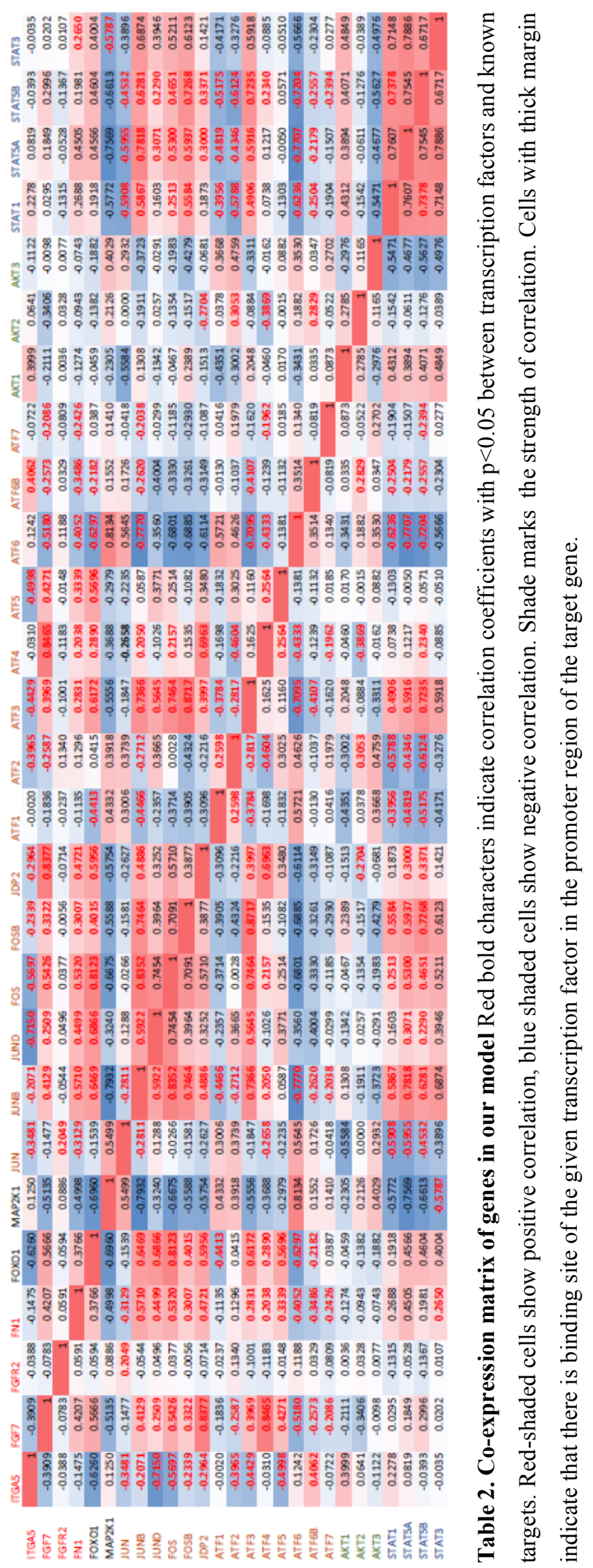




\section{RESULTS}

\subsection{Altered protein expression of $\alpha_{5}$ integrin, $\mathrm{EDA}^{+} \mathrm{FN}, \mathrm{KGF}$ and FGFR2 in psoriatic NL skin}

Healthy skin and psoriatic NL skin were investigated for differences in the expressions of $\alpha_{5}$ integrin, $\mathrm{EDA}^{+} \mathrm{FN}, \mathrm{KGF}$ and FGFR2 before and 24, 48 hours after tape stripping. Immunofluorescent staining revealed a striking difference in all protein expressions examined even without tape stripping between normal and psoriatic NL skin (Figure 6). Mild mechanical stress introduced by tape stripping of the skin did not lead to any obvious changes in $\alpha_{5}$ integrin, $\mathrm{EDA}^{+} \mathrm{FN}, \mathrm{KGF}$ and FGFR2 expressions or distributions at 24 and 48 hours after treatment in NL skin. In healthy control sections a slight increase in all protein expression was observed based on immunostaining (Figure 7).

a

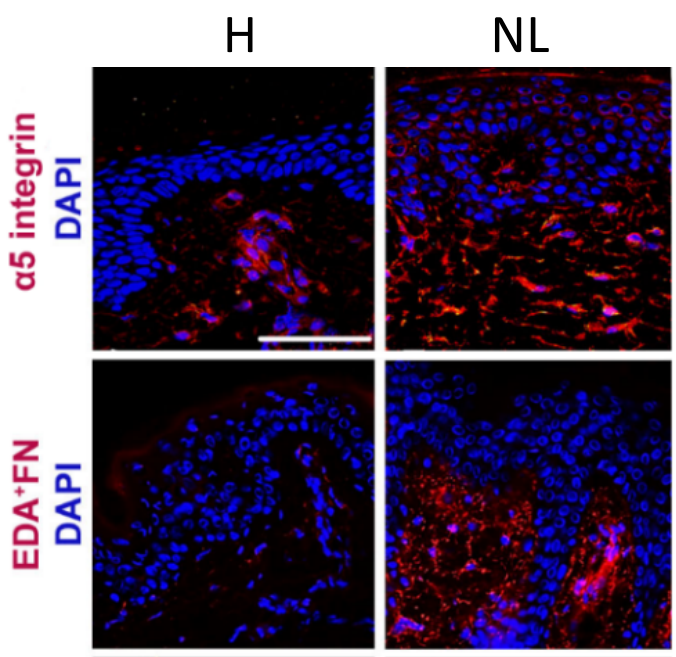

b

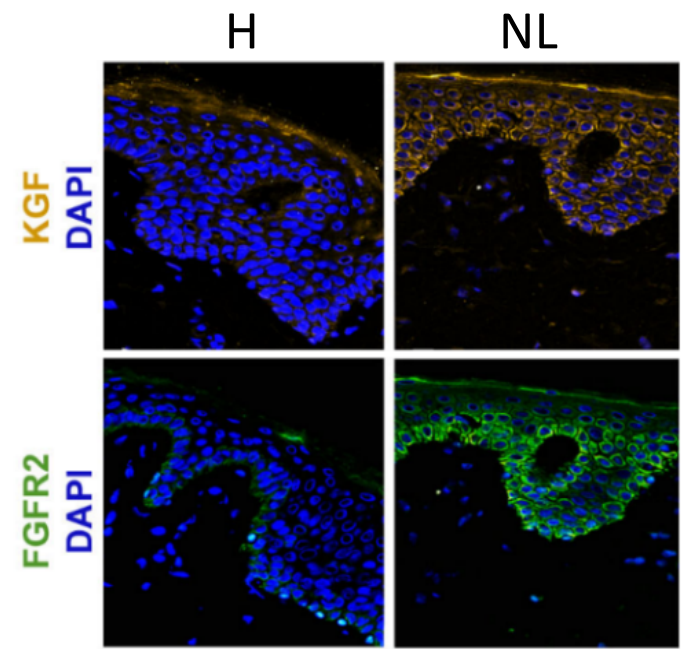

Figure 6. Increased expression of $\alpha_{5}$ integrin, EDA ${ }^{+}$FN, KGF and FGFR2 in NL skin without mechanical stress stimuli. Immunofluorescent analysis of $\alpha_{5}$ integrin, EDA ${ }^{+} \mathrm{FN}, \mathrm{KGF}$ and FGFR2 expression in $\mathrm{H}$ (healthy) and NL (non-lesional) skin ( $\mathrm{n}=6$ ). Bar: $50 \mu \mathrm{m}$ 
a

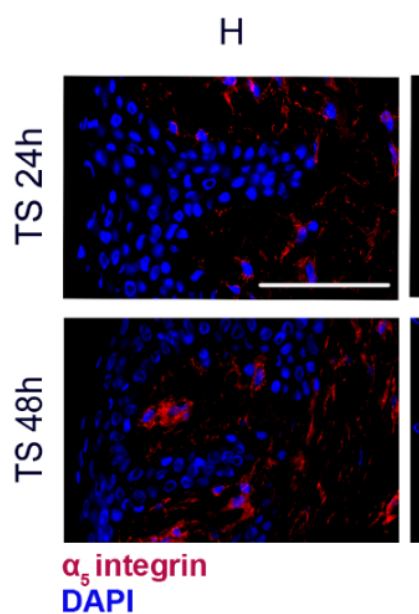

C

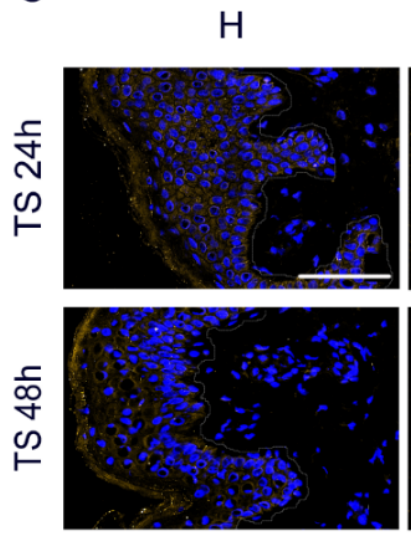

KGF

DAPI

DAPI b

$\mathrm{NL}$
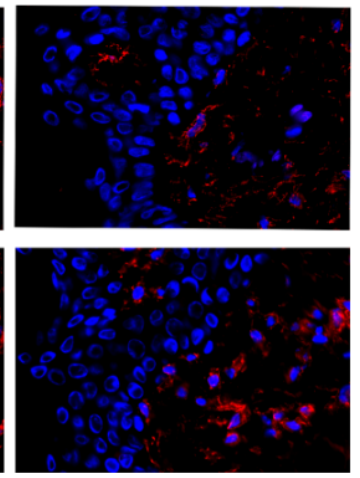

$\mathrm{NL}$
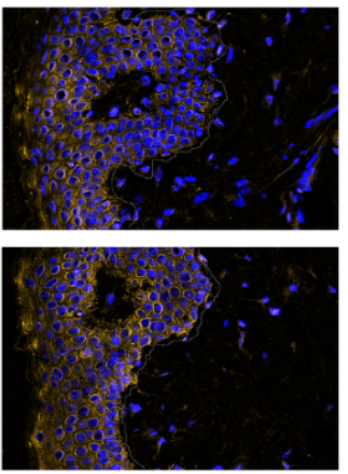

d

$\mathrm{H}$
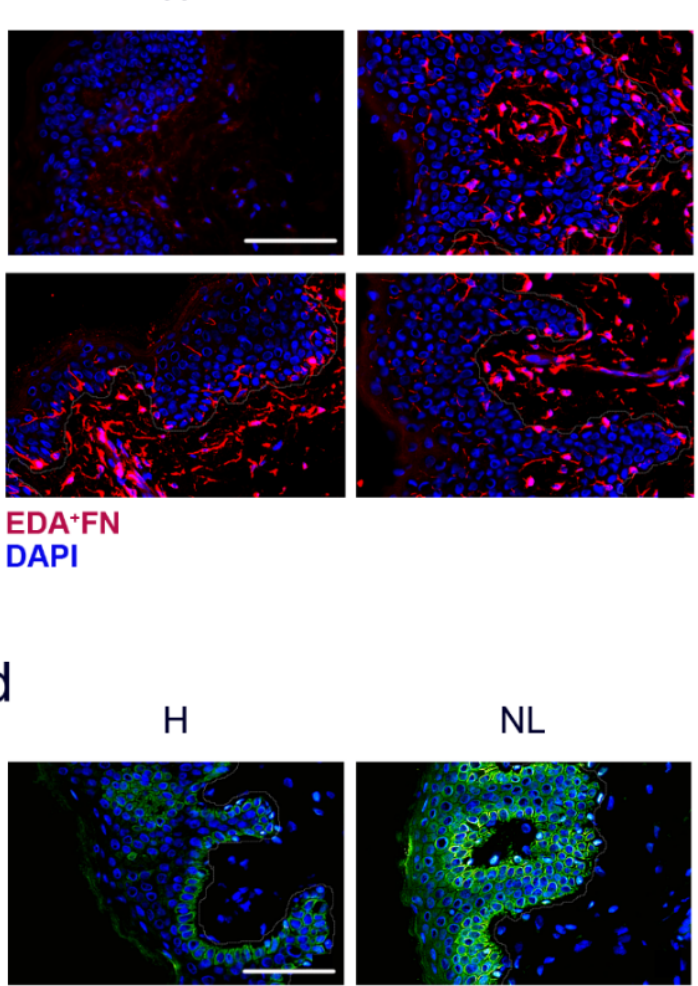

EDA+FN

DAPI
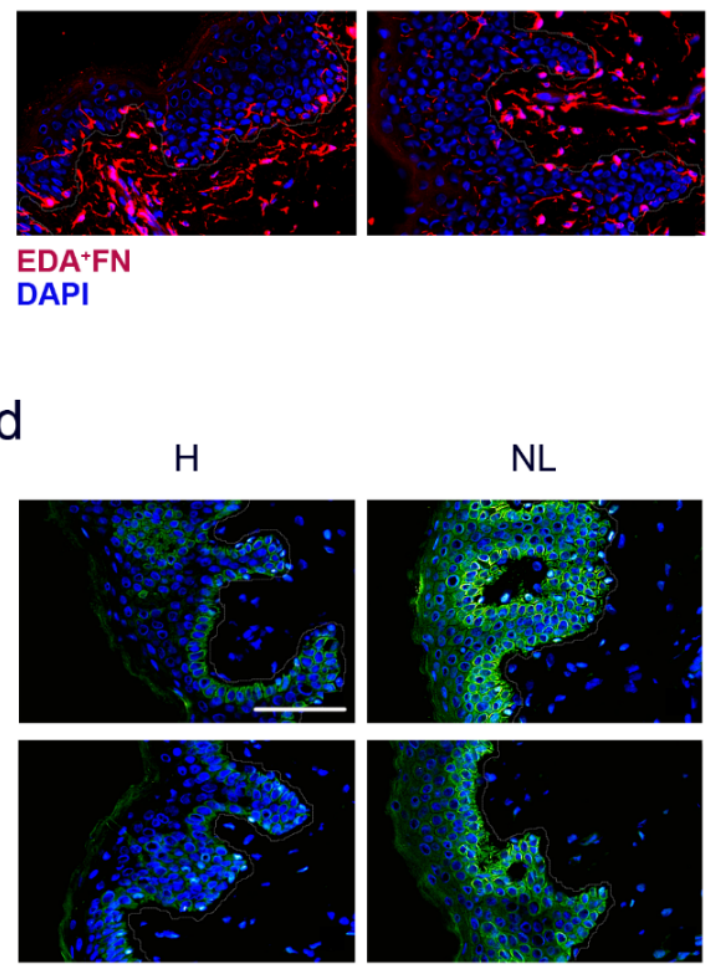

FGFR2

DAPI

Figure 7. Mild mechanical stress induced by tape stripping has no effect on the expression of $\alpha_{5}$ integrin, EDA $^{+}$FN, KGF or FGFR2 in NL psoriatic skin and only a mild effect on healthy skin. The protein expression of $\alpha_{5}$ integrin (a), EDA ${ }^{+} \mathrm{FN}$ (b), KGF (c) and FGFR2 (d) was visualized by immunofluorescent staining 24 and 48 hours following tape stripping in $\mathrm{H}$ (healthy) and in NL (non-lesional) skin. Bar: $50 \mu \mathrm{m}$. 


\subsection{Determining temporal changes in protein production for downstream analysis}

The production of EDA ${ }^{+} \mathrm{FN}$ is the highest after 24 hours, whereas the expression of FN and FGFR2 remains similar in the first 48 hours starting at both $40 \%$ and $70 \%$ confluence of normal human fibroblast

FN, EDA ${ }^{+}$FN and FGFR2 protein levels were examined using flow cytometry at 6,12 , 24, 36 and 48 hours in two different states of confluence (40\% and $70 \%$ ) of normal human fibroblasts. FN protein level showed an increasing tendency with time and peaked at $36 \mathrm{~h}$ however this change did not reach the level of significance. In both $40 \%$ and $70 \%$ confluence states $\mathrm{EDA}^{+} \mathrm{FN}$ protein level was significantly elevated at $24 \mathrm{~h}$ compared to any other measured time points. FGFR2 protein level did not show any change during the first $48 \mathrm{~h}$. Protein production was similar at both $40 \%$ and $70 \%$ confluence in the examined timeframe (Figure 8).
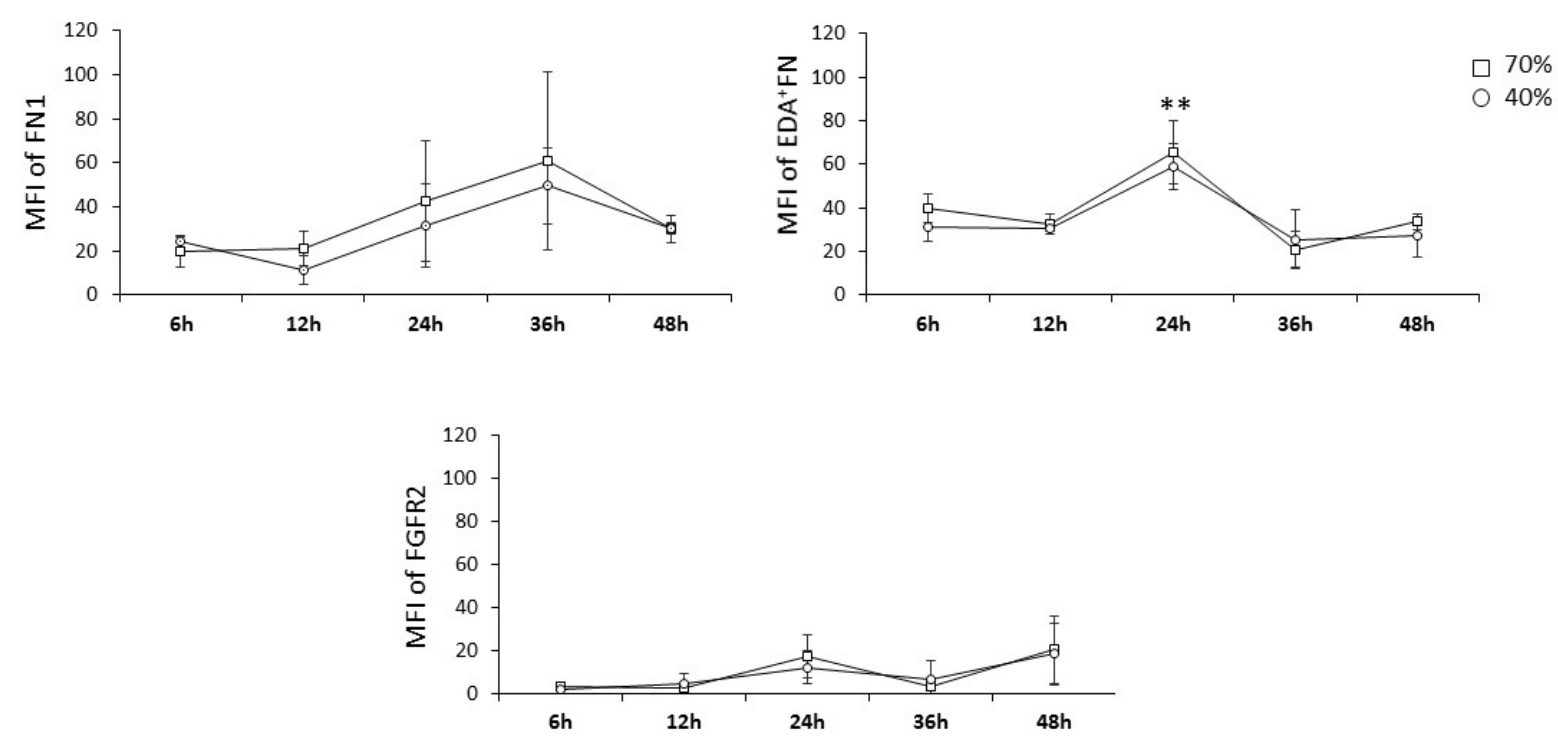

Figure 8. Flow cytometry measurement of FN, EDA ${ }^{+}$FN and FGFR2 protein levels at 6, 12, 24, 36 and 48 hours at $40 \%$ and $70 \%$ of confluence of normal human fibroblasts. MFI: mean fluorescence intensity. Data are represented as mean $\pm \mathrm{SD}(\mathrm{n}=3), * * \mathrm{p}<0.01$. 


\subsection{KGF treatment of healthy human fibroblasts leads to the elevation of EDA $^{+}$FN production}

$\mathrm{EDA}^{+} \mathrm{FN}$ and $\mathrm{KGF}$ are known to stimulate keratinocyte proliferation. KGF induces the expression of the major FN cell surface receptor $\alpha_{5} \beta_{1}$ integrin. Given the differences in $\mathrm{EDA}^{+} \mathrm{FN}$ and KGF protein levels in healthy and NL psoriatic skin, we set out to investigate a putative regulatory connection between these two molecules. Exogenous treatment of cultured healthy fibroblasts with KGF for 24 hours increased the level of the $\mathrm{EDA}^{+} \mathrm{FN}$ splice variant, but not the total FN protein based on immunostaining and flow cytometry measurements (Figure $9 a, b$ ). A similar increase in the $\mathrm{EDA}^{+} \mathrm{FN}$ mRNA level was detected, while the total FN mRNA remained unchanged (Figure 9 c). We also investigated this effect of KGF on normal human keratinocytes and on the keratinocyte cell line, HaCaT. As expected, keratinocytes and $\mathrm{HaCaT}$ cells expressed the $\mathrm{FN}$ and the EDA ${ }^{+} \mathrm{FN}$ at a very low level compared to fibroblasts (Figure 10). However, upon in vitro KGF treatment these cells did not display detectable changes in mRNA and protein expressions of EDA ${ }^{+} \mathrm{FN}$ and total FN (Figure $10 a-c$ ). 
a

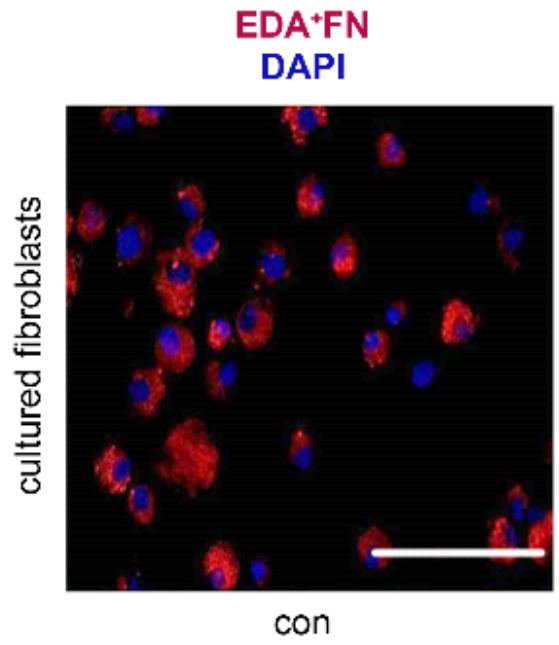

b
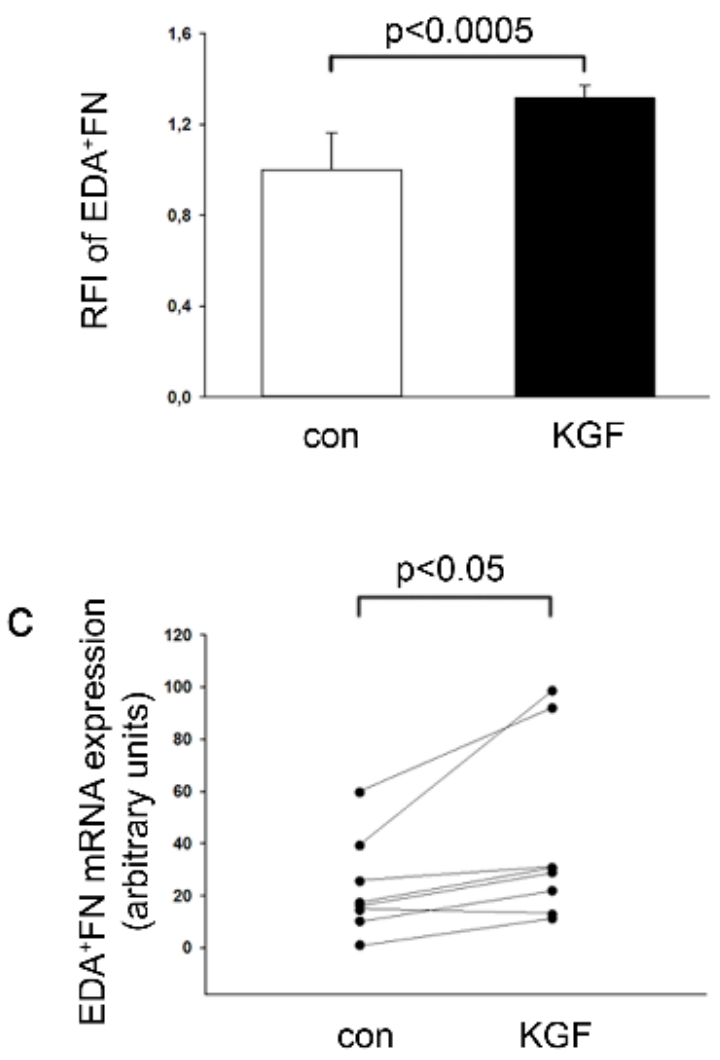

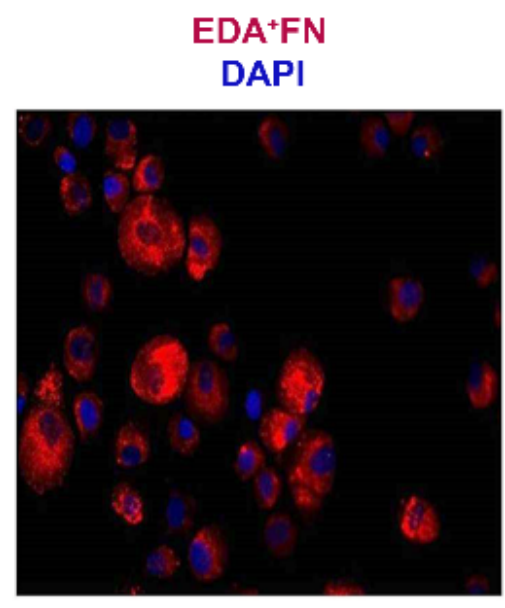

KGF
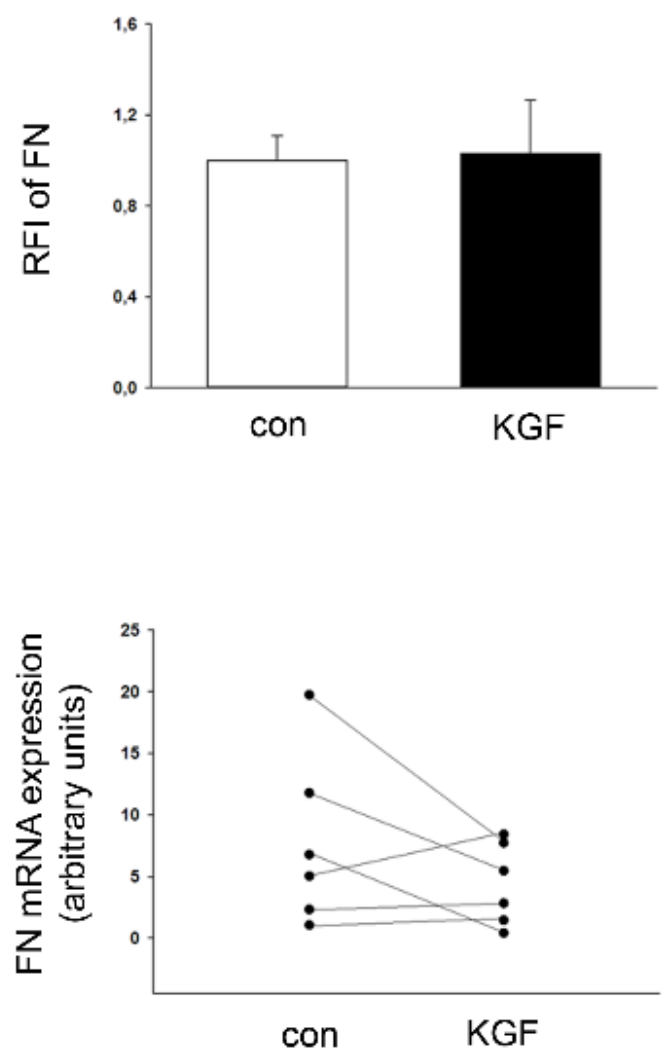

Figure 9. The expression of $\operatorname{EDA}^{+} \mathrm{FN}$ is induced by KGF in normal human fibroblasts. KGF treated fibroblasts and the change in expression in $\mathrm{FN}$ and $\mathrm{EDA}^{+} \mathrm{FN}$ at 24 hours. a) Immunofluorescent detection of $\mathrm{EDA}^{+} \mathrm{FN}$. b) Flow cytometry measurement of $\mathrm{EDA}^{+} \mathrm{FN}$ and FN levels following KGF treatment. RFI: relative fluorescence intensity. c) FN or EDA ${ }^{+} \mathrm{FN}$ mRNA expression following KGF stimulation. Values are expressed in arbitrary units. Con: control. Data represent the mean \pm SEM (n=6). Bar: $50 \mu \mathrm{m}$. 
a
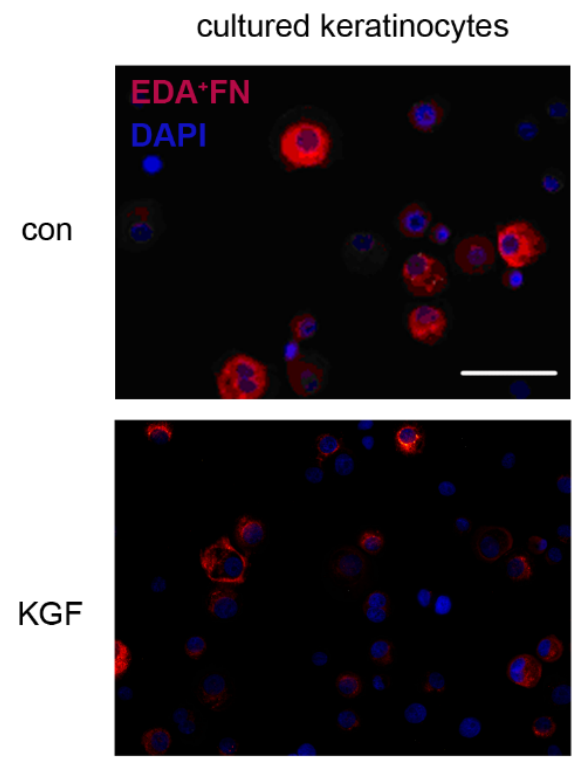

b

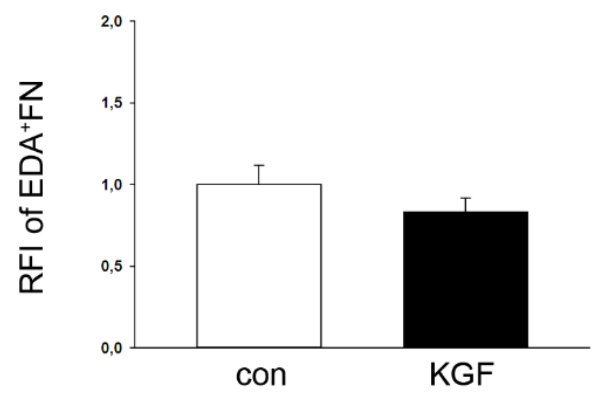

C

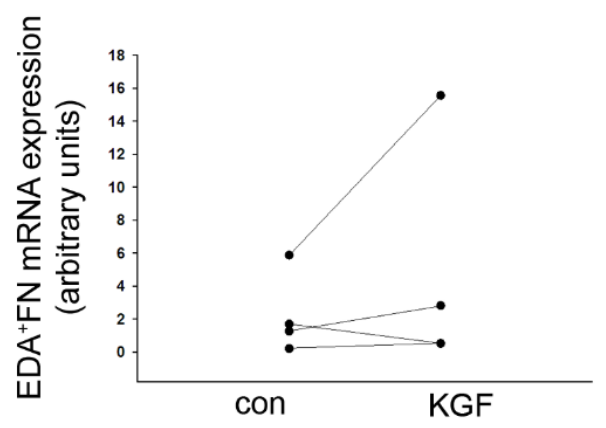

cultured HaCaTs
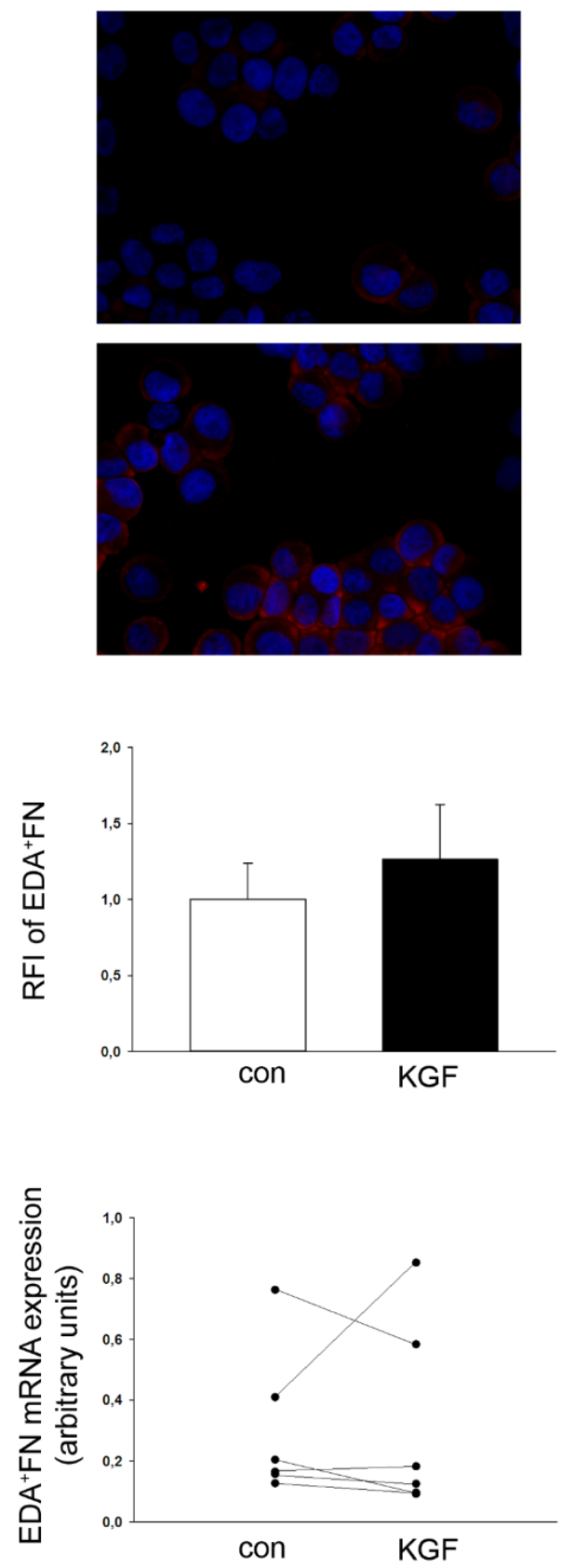

Figure 10. Exogenous KGF treatment has no effect on $\mathbf{E D A}^{+} \mathrm{FN}$ expression of keratinocytes and HaCaT cells. The expression of $\mathrm{EDA}^{+} \mathrm{FN}$ was visualized by immunostaining (a), its protein amount was quantified by flow cytometry (b) and mRNA expression was determined by real-time RT-PCR measurements (c) following 24 hours of $25 \mathrm{ng} / \mathrm{ml} \mathrm{KGF}$ treatment of healthy human keratinocytes and HaCaT cells. RFI: relative fluorescence intensity. Values are expressed in arbitrary units. Bar: $50 \mu \mathrm{m}$. 


\subsection{Expression of FGFR2 splice variants in fibroblasts, melanocytes and keratinocytes}

Two splice variants have been identified for FGFR2 designated as FGFR2-IIIb and FGFR2-IIIc that have different ligand binding preferences. These results were based on mitotic activity measurements (39). KGF has been shown to act on the FGFR2-IIIb variant increasing cellular proliferation (37). We determined the expression of the splice variants in healthy fibroblasts, melanocytes and keratinocytes using specific primers designed for RT-PCR, revealing that melanocytes and keratinocytes expressed the FGFR2-IIIb only, while fibroblasts mainly expressed the FGFR2-IIIc variant (Figure $11 a, b$ ).
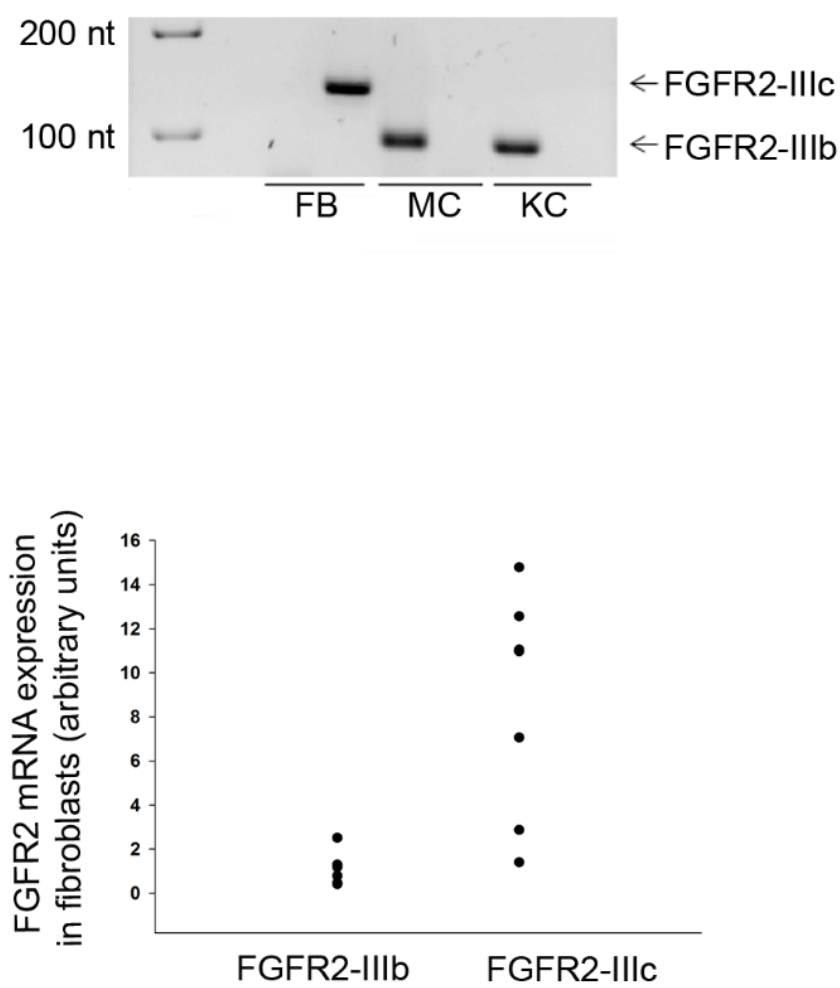

Figure 11. Human fibroblasts in culture mainly express the FGFR2-IIIc, while melanocytes and keratinocytes the FGFR2-IIIb splice variant of FGFR2. a) RT-PCR products specific for FGFR2-IIIb and IIIc were run on a $2 \%$ agarose gel of cultured human fibroblasts (FB), melanocytes (MC) and keratinocytes. b) FGFR2 mRNA expression by fibroblasts for the two investigated splice variants detected by real-time RT-PCR. Values are expressed in arbitrary units. 


\subsection{MAPK signaling is involved in the regulation of $\mathrm{EDA}^{+} \mathrm{FN}$ controlled by $\mathrm{KGF}$ in healthy fibroblasts}

FGF signals (including KGF) are coordinated by four major pathways: the RAS-RAFMAPK, the PI3-AKT, the STAT and the PLC $\gamma$ signaling $(38,44)$. In order to get a better insight into the modulation of FN expression by KGF in cultured fibroblasts derived from healthy skin, we performed blocking experiments targeting key molecules of the signal transduction pathways using specific inhibitors available for MEK1 (MAPK), AKT1/2 (PI3-AKT), STAT1 and STAT3 (STAT) either alone or in combination. After $24 \mathrm{~h}$ of inhibitory treatment the expressions of FN and $\mathrm{EDA}^{+} \mathrm{FN}$ were determined by flow cytometry and RT-PCR. The KGF induced $\mathrm{EDA}^{+} \mathrm{FN}$ elevation was abolished by the inhibition of MEK1 and returned to the level of control fibroblasts (Figure 12 a). In contrast, blocking AKT1/2 did not have an effect on $\mathrm{EDA}^{+} \mathrm{FN}$ protein expression (Figure $12 \mathrm{c}$ ). The inhibition of STAT1 or STAT3 did not influence KGF-mediated changes in $\mathrm{EDA}^{+} \mathrm{FN}$ levels, however, impairing these signaling molecules resulted in a KGF independent elevation of both $\mathrm{FN}$ and EDA ${ }^{+} \mathrm{FN}$ protein levels that was significant in the case of STAT1 inhibition (Figure 12 b). 
a

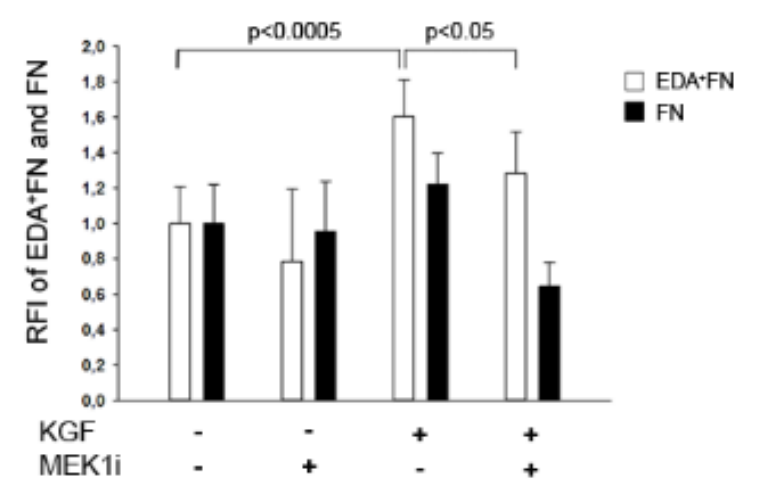

b

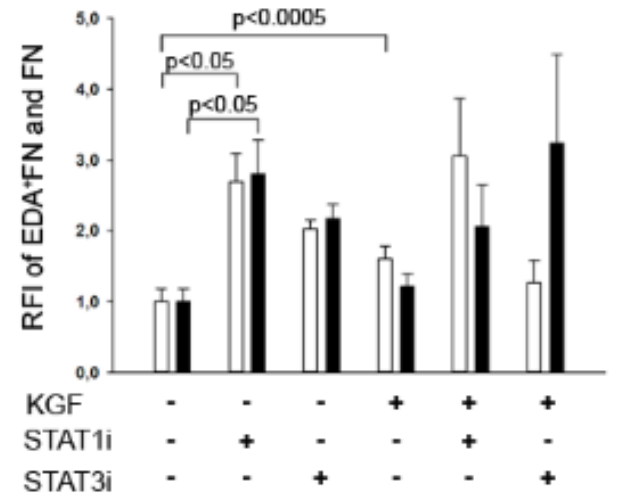

C

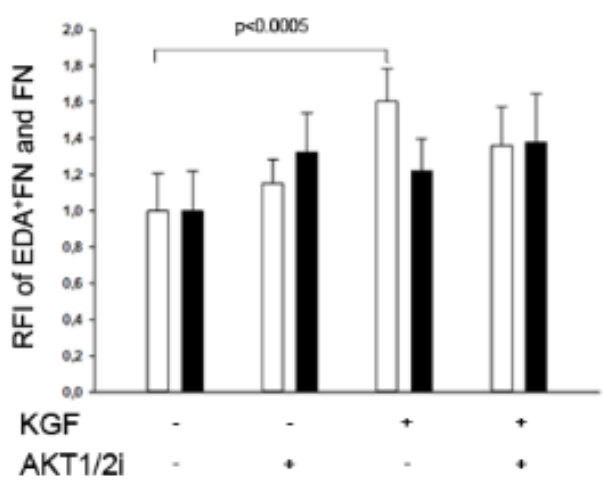

Figure 12. KGF influenced elevation of the $\mathrm{EDA}^{+} \mathbf{F N}$ is mediated through MAPK. Exogenous KGF treatment triggered increase of EDA ${ }^{+} \mathrm{FN}$ and FN is not influenced by STAT1, STAT3 or AKT1/2 inhibition. a) FN and $\mathrm{EDA}^{+} \mathrm{FN}$ levels of healthy fibroblasts treated with KGF alone or in combination with MEK1 inhibitor. b) Following treatment of healthy fibroblasts with KGF alone or produced by in combination with inhibitors for STAT1, STAT3 or both. c) The level of EDA ${ }^{+}$FN and FN was measured by flow cytometry following $24 \mathrm{~h}$ of KGF incubation with or without AKT1/2 inhibitor. Untreated cells or treated with the MEK1, AKT1/2, STAT1 and STAT3 inhibitor alone were used as controls. Data represent the mean $\pm \operatorname{SEM}(n=6)$. RFI: relative fluorescence intensity.

\subsection{Inhibition of the RAS-RAF-MAPK, PI3-AKT and STAT signaling pathways affect fibroblast viability}

Next we investigated the effect of blocking the three main signaling pathways (RASRAF-MAPK, PI3-AKT and STAT) in fibroblasts using the STAT1, STAT3, MEK1 and AKT $1 / 2$ inhibitors. Cell viability was examined after 24 hours of inhibition by microscopy (based on cellular morphology). Viable cell numbers showed large degree of reduction following STAT1-STAT3, STAT1-STAT3-MEK1 or STAT1-STAT3-AKT1/2 combined treatments (Figure 13). Using STAT1 or STAT3 inhibitors separately did not influence fibroblast viability 
while blocking both STAT proteins simultaneously significantly decreased the survival of fibroblasts however further inhibition of AKT and MAPK pathways did not increase cell death.

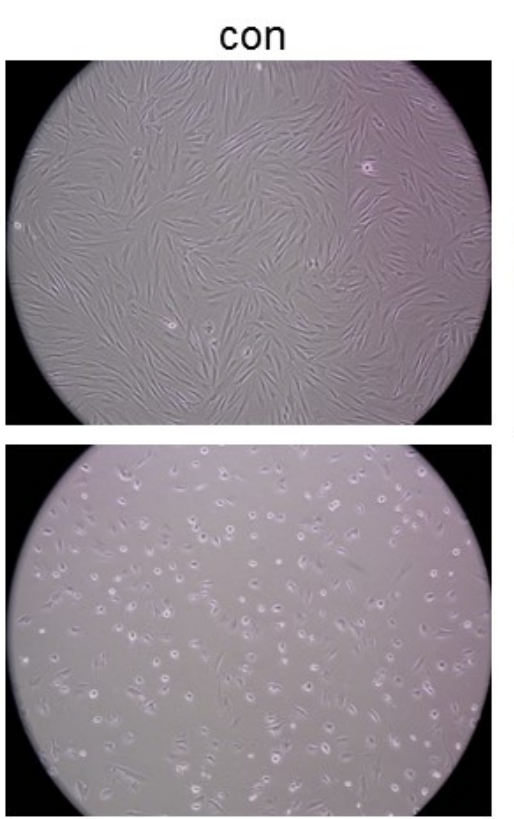

STAT1i - STAT3i

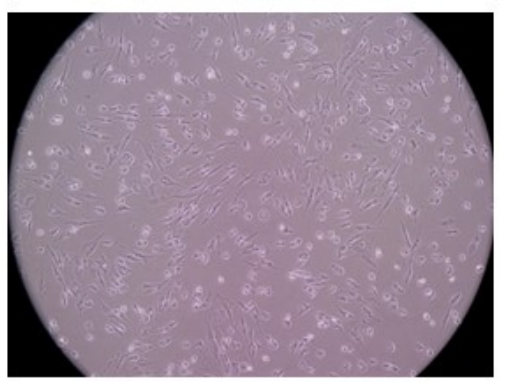

STAT1i - STAT3i - MEK1i - AKT1/2i
STAT1i
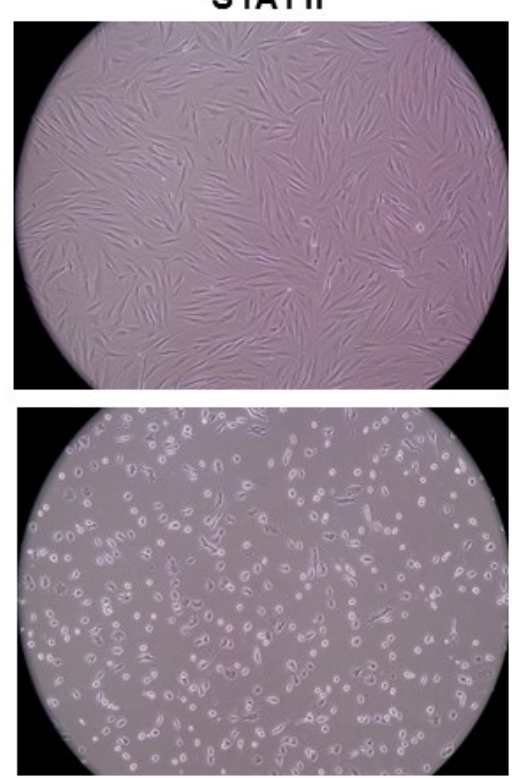

STAT1i - STAT3i - MEK1i
STAT3i
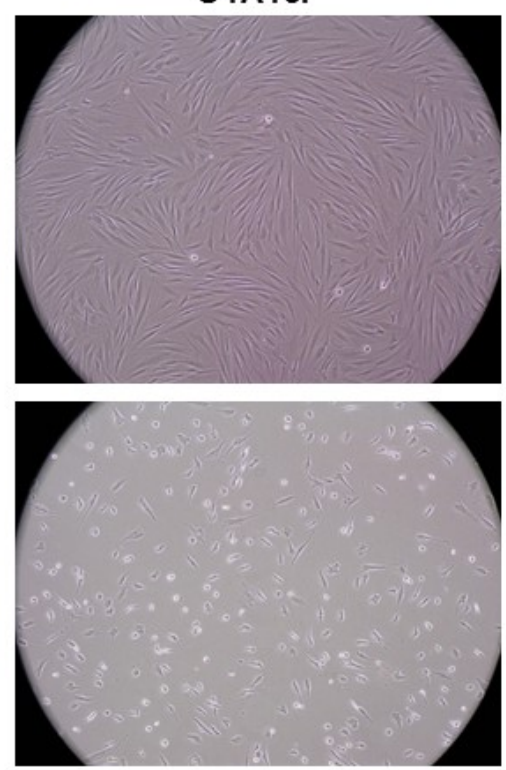

STAT1i - STAT3i - AKT1/2i

Figure 13. Combined blocking of the RAS-RAF-MAPK, PI3-AKT and STAT signaling pathways result in fibroblast cell death. Healthy fibroblasts were detected by microscope following $24 \mathrm{~h}$ treatment with STAT1, STAT3 alone or in combination with inhibitors for MEK1, AKT1/2 or both. Ten-fold magnification. Con: control, STAT1i: STAT1 inhibitor, STAT3i: STAT3 inhibitor, MEK1i: MEK1 inhibitor, AKT1/2i: AKT1/2 inhibitor. $(n=3)$ 


\subsection{Abnormal STAT1 activation in psoriatic skin plays a role in the regulation of both FN and EDA ${ }^{+}$FN}

To investigate further, we compared $\mathrm{FN}$ and $\mathrm{EDA}^{+} \mathrm{FN}$ expressions between derived from fibroblasts healthy and psoriatic NL skin 24 hours after STAT1 or STAT3 inhibition in culture. In contrast to healthy controls, blockade of STAT1 did not lead to the elevation of total $\mathrm{FN}$ and the $\mathrm{EDA}^{+} \mathrm{FN}$ splice variant in fibroblasts from NL skin changes upon STAT3 impairment were not significant (Figure 14 a).

Therefore, we investigated the phosphorylation pattern of STAT1 at Tyr701 and Ser727 positions that are known to be key amino acid modifications leading to dimerization and influencing activity. Immunofluorescent staining for the phosphorylated Ser727 was highest in lesional psoriatic skin, lower, but clearly detectable in healthy skin, whereas NL skin samples showed the lowest intensity. In two out of four investigated NL samples phosphorylation was undetectable (Figure 14 b). Staining for the phosphorylated Tyr701 showed a much less noticeable but similar pattern. In samples of patients where no serine phosphorylation was detected in the NL skin, the staining for the phosphorylated Tyr701 was also not visible in either NL or lesional areas. To elucidate whether differences observed in STAT1 activity among patients correlated with the severity of the disease, PASI scores of donor patients were compared. The patients whose NL skin was negative for phosphorylations of STAT1 had a lower PASI score (12.4 and 17.8), whereas low STAT1 activity in NL skin was associated with a higher PASI score (19.6 and 20). 
a

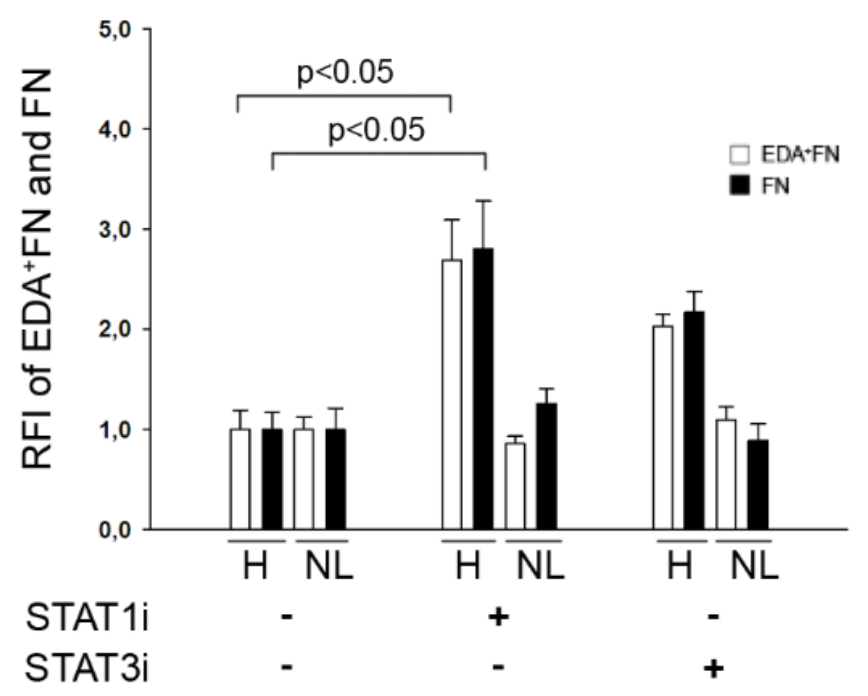

b

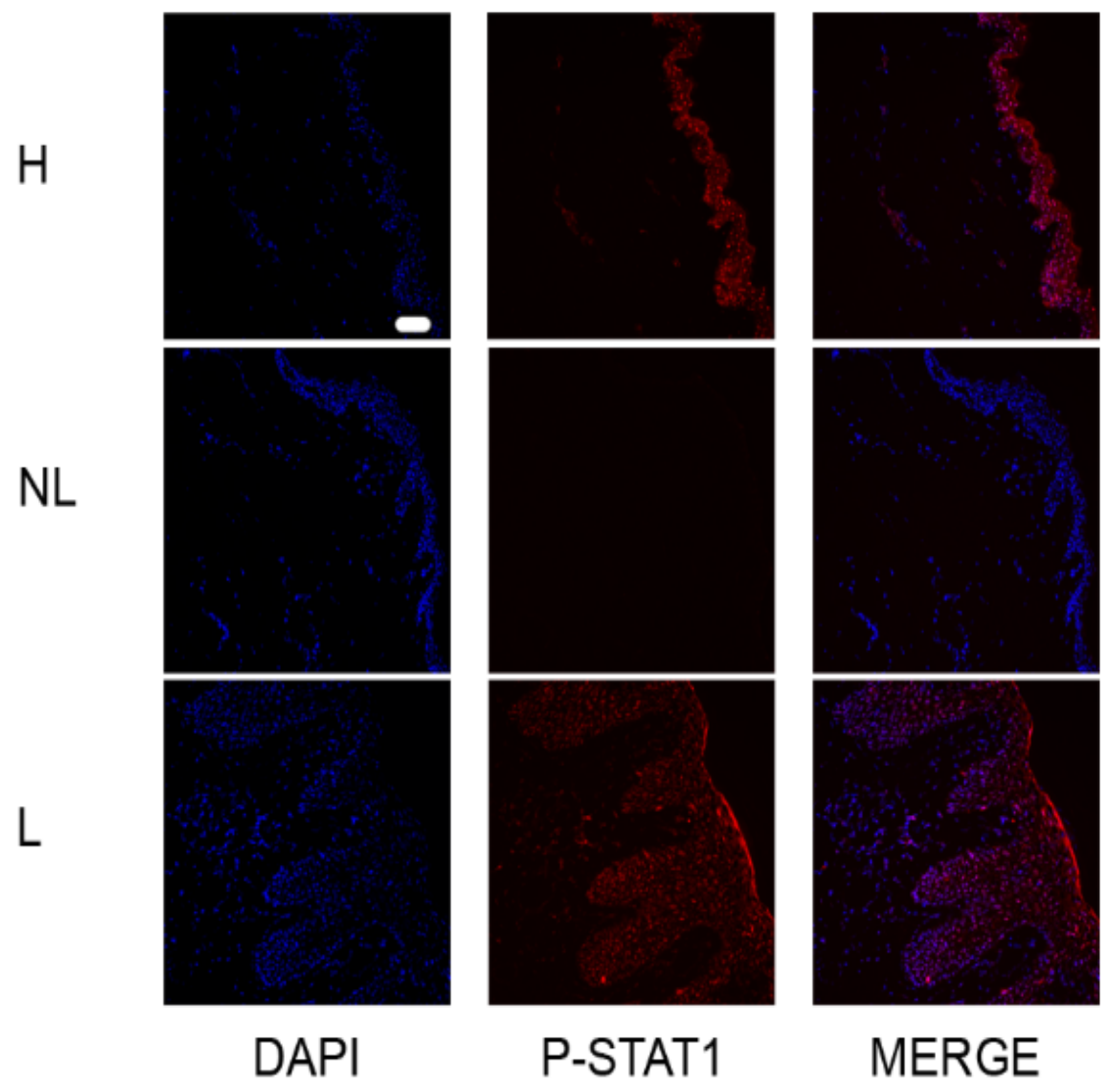

(Ser 727)

Figure 14. Altered STAT1 regulation of $\mathrm{EDA}^{+} \mathrm{FN}$ and $\mathrm{FN}$ expression in psoriasis. a) The effect of STAT1 and STAT3 inhibition on FN and $\mathrm{EDA}^{+} \mathrm{FN}$ in fibroblasts derived from healthy and non-lesional skin. b) Immunofluorescent analysis of STAT1 (Ser727) phosphorylation. H: healthy, NL: non-lesional, and L: lesional skin. Data represent the mean $\pm \operatorname{SEM}(n=6, n=4)$. RFI: relative fluorescence intensity. Bar: $50 \mu \mathrm{m}$. 
Immunhistochemistry analysis revealed the presence of pSTAT1 (Ser727) in the both the epidermis and the dermis. STAT1 activity showed a strong correlation with PASI score. High PASI scores (eg. 19.6) were typically coupled with intensive pSTAT1 (Ser727) staining in the lesional skin and in these patients, the NL skin also showed a slight STAT1 activity. In contrast, patients with low PASI score (eg. 9.8) nearly no STAT1 activity was detectable in the NL skin. Indicating that pSTAT1 (Ser727) activation of the NL skin and the PASI scores of patients decreased in parallel. Activation of STAT1 Tyr (701) form decays rapidly and only in samples obtained from patient with high PASI score can be observed, where the presence of both phosphorylated forms is much more intensive (Table 3). We compared NL skin samples near and far from the lesion for the extent of activation for the two different pSTAT1 forms in order to test whether the lesional area has an effect on surrounding NL skin. It was assessed that STAT1 activity is independent from the distance from the lesion indicating a sharp border between the NL and lesional skin (Figure 15). The figure 15. also shows that the strongest STAT1 activation is detected in psoriatic L skin. 
PASI: 19.6
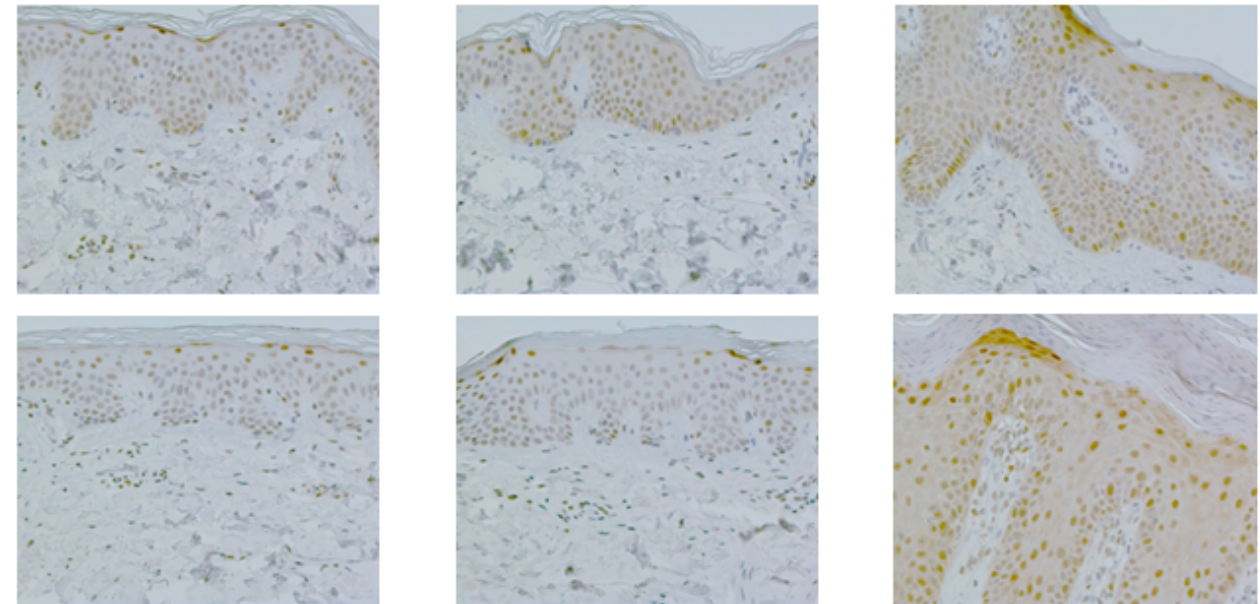

PASI: 12.4

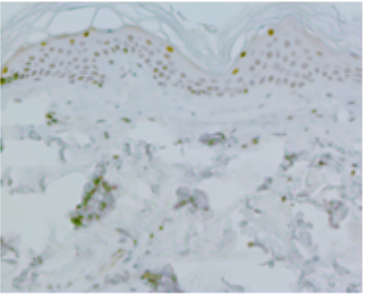

NL (far)

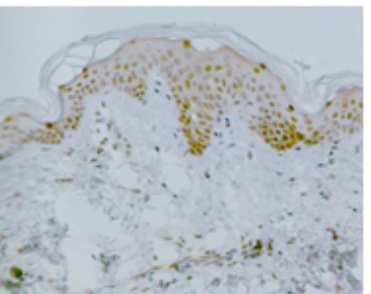

$\mathrm{H}$

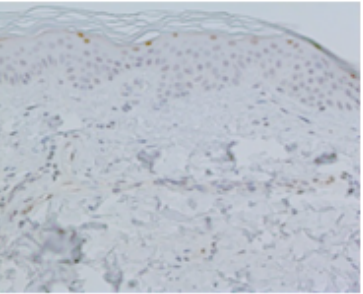

$\mathrm{NL}$ (near)

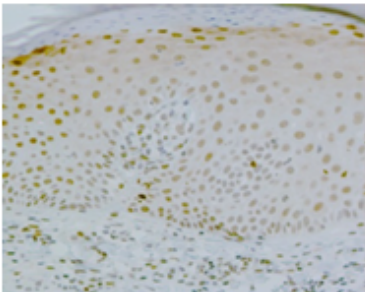

$\mathrm{L}$

Fure 15. STAT1 Ser727 phosphorylated form shows high degree of activation in lesional (L) skin, it is present to a lesser extent in healthy skin, while hardly detectable in non-lesional (NL) skin by immunohistochemistry. NL skin of high PASI patients include active STAT1 in contrast with NL skin of low PASI patients. $(n=3)$

\begin{tabular}{|c|c|c|c|c|c|c|c|c|c|c|c|c|c|}
\hline & \multicolumn{6}{|c|}{ pSTAT1 (Ser 727) } & \multicolumn{6}{|c|}{ pSTAT1 (Tyr701) } \\
\hline & & \multicolumn{2}{|c|}{ NL (far) } & \multicolumn{2}{|c|}{ NL (near) } & \multicolumn{2}{|c|}{ L } & \multicolumn{2}{|c|}{ NL (far) } & \multicolumn{2}{|c|}{ NL (near) } & \multicolumn{2}{|c|}{$\mathbf{L}$} \\
\hline \begin{tabular}{|l} 
PATIENT \\
\end{tabular} & PASI & $\mathbf{E}$ & D & $\mathbf{E}$ & D & $\mathbf{E}$ & D & $\mathbf{E}$ & D & $\mathbf{E}$ & D & $\mathbf{E}$ & D \\
\hline 1 & 19.6 & + & + & + & - & + & + & - & - & $+/-$ & $+/-$ & - & - \\
\hline 2 & 12.4 & $+/-$ & $+/-$ & $+/-$ & $+/-$ & + & + & - & - & - & - & - & - \\
\hline 3 & 9.8 & - & - & - & - & + & + & - & - & - & - & - & - \\
\hline
\end{tabular}

Table 3. Activation of the pSTAT1 Ser(727) and pSTAT1 Tyr(701) forms in epidermis and dermis of NL and $L$ skin with PASI scores of 3 psoriatic patients. NL: non-lesional, and L: lesional skin, E: epidermis, D: dermis; + (red): high positivity, +/- (yellow): low positivity, - (green): negative 


\subsection{In silico model construction}

We constructed an in silico model based on our in vitro results involving KGF- and FNsignaling and the underlying transcriptional regulation network (Figure 16., Table 1-2.). Our data already suggested the participation of MAPK signaling in KGF induced FN splicing. The generated co-expression matrix implied a potential role of peptidyl-prolyl cis-trans isomerase (PPIG), a protein important in both protein folding and splicing (84), which is regulated by MEK1 induced AP-1. Changes in MEK1 activity could lead to the modulation of FN splicing through PPIG resulting in elevated $\mathrm{EDA}^{+} \mathrm{FN}$ levels. Our model also indicated that STAT3 negatively regulates the expression of MEK1. This suggested inhibitory effect of STAT3 on MEK1 may account for the increased EDA ${ }^{+} \mathrm{FN}$ production upon STAT inhibition. However, our model did not explain our data on the significant increase in $\mathrm{EDA}^{+} \mathrm{FN}$ and $\mathrm{FN}$ following STAT1 inhibition in normal fibroblasts. The schematic summary model of the KGF induced changes on FN based on our results and public databases (in vivo, in vitro and in silico) of normal skin is presented in Figure 17. 


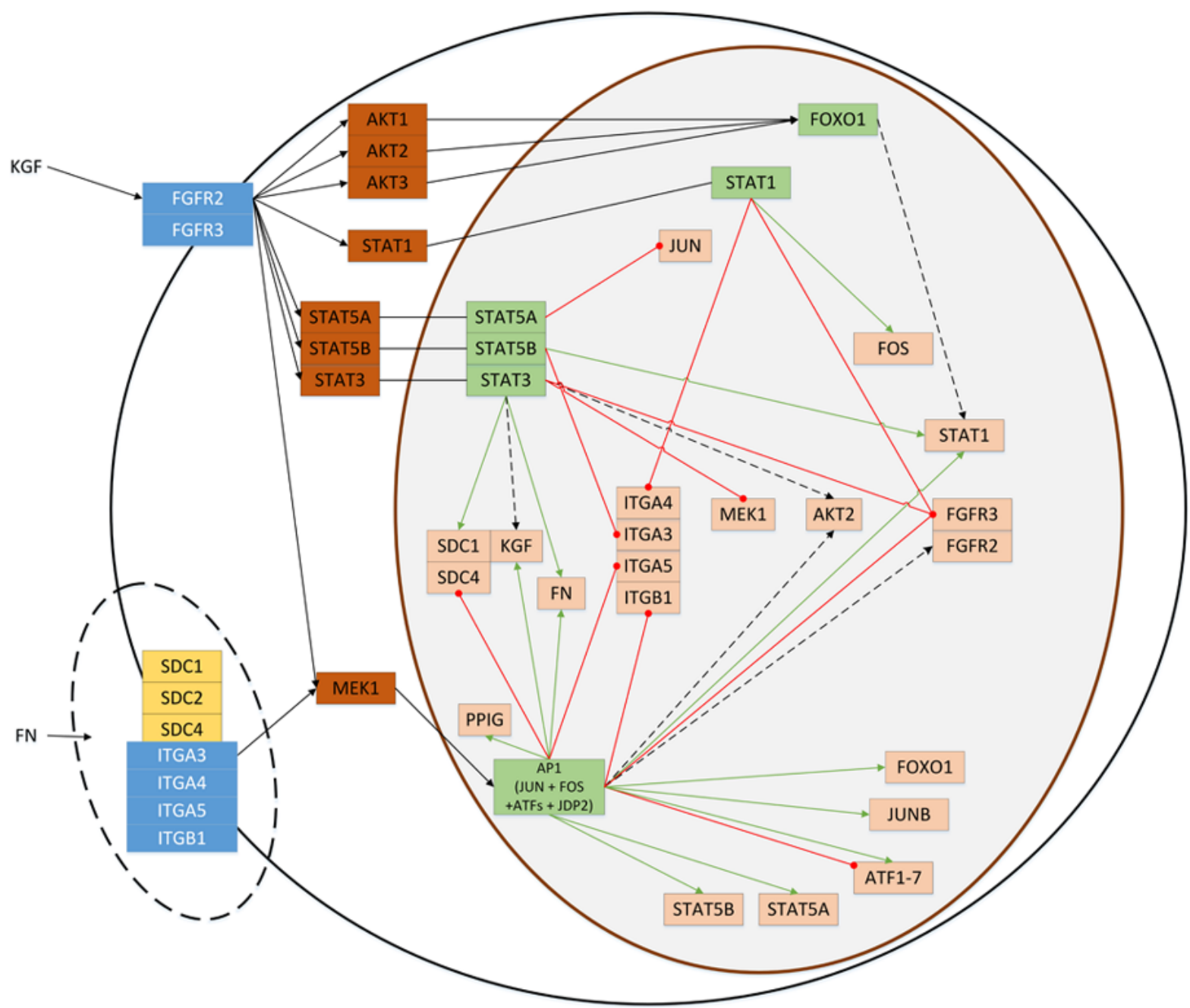

Figure 16. In silico model of KGF and FN signaling. Green arrow: positive transcriptional regulation; Red arrow with circle arrowhead: negative transcriptional regulation; Arrows with dashed lines: undetermined direction of regulation. 


\section{DISCUSSION}

Despite the massive amount of research on psoriasis the underlying cellular and molecular mechanisms are only partially understood. One of the important characteristics of psoriasis is that the seemingly healthy looking skin of patients already carries certain molecular and structural abnormalities, which are likely to serve as a microenvironment favouring the manifestation of the disease. Previous studies have mainly focused on the characterization of the lesional skin and on differences between NL and lesional skin. However, the examination and comparison of healthy and NL skin in order to gain more knowledge regarding the abnormal processes and properties of NL skin received much less attention. Therefore, we focused our research to study irregularities that are already present in the NL skin.

Psoriatic lesions are characterized by hyperproliferation of keratinocytes, where KGF is known to play an important role. At the protein level both KGF and its receptor FGFR2 were demonstrated to be elevated in lesional skin compared to normal skin (85). An increased expression of both KGF and FGFR2 mRNA were also described by others in NL as well as in lesional tissue $(85,86)$. KGF stimulates keratinocyte proliferation and it influences terminal differentiation $(40,87)$. The only known source of KGF in the skin are fibroblasts, however keratinocytes can mediate KGF production in fibroblasts through IL-1 $(88,89)$, establishing a double paracrine regulatory loop, controlled by the AP-1 subunits c-Jun and JunB and directing the regeneration of the epidermis and maintaining tissue homeostasis in the skin (90). It was reported that microRNA-125 (miR-125) is downregulated in psoriatic lesional tissue (91). miR125 is known to have a negative influence on keratinocyte proliferation, partially by downregulating FGFR2 expression and driving keratinocytes towards differentiation, which also includes a change in the production of different ECM components (91).

Alterations of the ECM are also part of the pathogenesis of psoriasis and increasing body of evidence indicates that the ECM is equally important under both normal and pathological conditions. By interacting with cell surface receptors (i.e. integrins), the different ECM components provide mechanical and biochemical signals to cells, influencing cellular behavior, affecting cell growth, differentiation, survival and ECM remodelling. ECM defects have been observed in the NL skin including disruption of the laminin layer leading to impaired keratinocyte adhesion to the basement membrane associated with aberrant expression of $\alpha 5 \beta 1$ integrin and $\mathrm{EDA}^{+} \mathrm{FN}$ on keratinocytes $(18,92-94)$. Overexpression of $\alpha 5$ integrin and $\mathrm{EDA}^{+} \mathrm{FN}$ 
has already been reported in connection with psoriasis and our group demonstrated that one of the potential sources of EDA ${ }^{+} \mathrm{FN}$ in the psoriatic NL skin are activated keratinocytes (32). Another report on psoriatic NL skin has shown that $\mathrm{EDA}^{+} \mathrm{FN}$ was localized mainly at the epidermal-dermal junction (20). It is well established that $\alpha 5$ integrin and $\mathrm{EDA}^{+} \mathrm{FN}$ could play an important regulatory role in the abnormal epidermal homeostasis of psoriatic skin $(18,32)$, and more recent evidence suggests that $\mathrm{EDA}^{+} \mathrm{FN}$ could be crucial in activating immune cells $(30,95)$. The EDA motif encompasses two non-classical binding sites for $\alpha_{4} \beta_{1}$ and $\alpha_{9} \beta_{1}$ integrins (21), receptors present on the surface of T-cells $(96,97)$ that could enhance $\mathrm{T}$ cell migration and accumulation in $\mathrm{EDA}^{+} \mathrm{FN}$ containing tissues, such as the skin. Moreover, both resting and activated Th1 cells but not Th2 cells express $\mathrm{EDA}^{+} \mathrm{FN}$. Interestingly, activated Th1 cells express lower amount of FN, but with a much higher $\mathrm{EDA}^{+} \mathrm{FN} / \mathrm{FN}$ ratio then resting ones (95). $\mathrm{EDA}^{+} \mathrm{FN}$ induces proinflammatory cytokines encoding genes and matrix metalloproteinases in $\mathrm{T}$ cells similarly to lipopolysaccharides (30). The $\mathrm{EDA}^{+} \mathrm{FN}$ mediated promotion of inflammatory responses takes place through TLR4 stimulation and leads to the increased expression of the tumour necrosis factor (TNF)- $\alpha$, IL-1 $\beta$, interleukin-6 (IL-6) and interleukin12 (IL-12), interleukin-23 (IL-23) and interferon- $\alpha$ (IFN- $\alpha$ ), contributing to Th1 and Th17 cell mediated cutaneous inflammation $(98,99)$. These cytokines enhance the expression of intracellular adhesion molecule-1 (ICAM-1), vascular cell adhesion molecule-1 (VCAM-1) and endothelial expression of E-selectin as well as further recruitment and invasion of $\mathrm{T}$ cells into the tissue (100). The newly recruited Th1 cells produce more EDA ${ }^{+} \mathrm{FN}$ thereby closing the vicious cycle.

$\mathrm{EDA}^{+} \mathrm{FN}$ was also suggested to promote acute inflammation and brain injury following cerebral ischemia in mice (82). $\mathrm{EDA}^{+} \mathrm{FN}$ is normally absent in human plasma, however patients with chronic inflammation and ischemic stroke have high plasma EDA ${ }^{+} F N$. The abnormally regulated overproduction of $\mathrm{EDA}^{+} \mathrm{FN}$ in psoriatic fibroblasts may be responsible not only for maintaining a local chronic inflammation in the skin, but by influencing plasma levels that could play a role in the systemic inflammation that has been described recently in psoriasis (101). The EDA ${ }^{+} \mathrm{FN}$ rich extracellular milieu in psoriatic skin could be crucial for maintaining the_characteristic epidermal changes, as well as the chronic inflammation in psoriatic lesions (for review see $(76,102)$ ). It has been reported that KGF stimulates EDA inclusion in a mouse mammary epithelial cell line (SCp2) (103). Although, the exact regulation of EDA ${ }^{+} \mathrm{FN}$ splicing 
is not completely clear, it is known that TGF- $\beta$ enhances EDA ${ }^{+} \mathrm{FN}$ production (104). Our in silico model on KGF and FN signaling corroborate our experimental results in suggesting the participation of MEK1 in KGF induced fibronectin splicing through peptidyl-prolyl cistrans isomerase (PPIG), a protein known to be important in protein folding and splicing (84) and regulated by MEK1 induced AP-1.

Autocrine feedback of several different FGFs through FGFRs exists under both normal and pathological conditions $(38,39,105)$. KGF exerts its effect mainly through FGFR2-IIIb, but also via FGFR2-IIIc and FGFR1 (37). Since both FGFR2 and FGFR1 can initiate MEK1 signalling, KGF could potentially modulate fibronectin splicing in a similar autocrine manner as other FGFs, most likely either through FGFR2-IIIc or FGFR1(39, 106) in fibroblasts. However, the participation of other receptors cannot be excluded either and further research is needed to understand the exact mechanism through which KGF affects FN splicing. Direct blocking of $\mathrm{EDA}^{+} \mathrm{FN}$ seems less feasible as a therapeutic approach, as blocking KGF or its receptors (107)

STAT1 is the founding member of the STAT family and it is activated by interferons (IFNs), and signaling from IL-27, IL-35 and TLRs (108). There is ample evidence implicating IFN $\gamma$ in the pathomechanism of psoriasis. Aberrant signaling and transcription have been reported for psoriatic keratinocytes with regard to suppressor of cytokine signaling 1 (SOCS1), a negative regulator of IFN $\gamma$ signaling (109), by supressing STAT1 and IRF-1 (110). The activation of STAT1 by IFN $\gamma$ induces SOCS3 expression and inhibits STAT3 signaling thereby suppressing Th17 development. On the other hand IL-6 and IL-23 stimuli leads to high SOCS1 expression that inhibits the IFN $\gamma$-mediated STAT1 activation and blocks the Th1 direction of $\mathrm{T}$-cell differentiation (111). In regulatory $\mathrm{T}$ (Treg) cells the absence of SOCS1 results in STAT1 hyperactivation and an increased secretion of IFN $\gamma$ and IL-17 (112). STAT1 mediates an antiviral and tumor-suppressor response, whereas STAT3 is known to be a protooncogene (113). STATs can form homo- or heterodimers that can activate different signaling pathways and regulate the expression of different sets of genes. Wan el at. have demonstrated that STAT1 and STAT3 play opposing roles in regulating IFN $\gamma$ expression in $\mathrm{CD}^{+} \mathrm{T}$ cells in vivo during chronic lymphotic choriomeningitis infection. Similarly, the IL-21 mediated IFN $\gamma$ and T-box 21 (TBX21) are reciprocally regulated by STAT1 and STAT3. IL-21 mediated STAT1 phosphorylation was increased in $\mathrm{CD}^{+}$cells from patients with STAT1 gain of function 
mutations and in patients with autosomal dominant hyper-IgE syndrome. $\mathrm{CD}^{+} \mathrm{T}$ cell cytotoxicity and apoptosis of mantle cell lymphoma are induced by STAT1 following IL-21 stimulation $(114,115)$. The IL-6-mediated activation of STAT1 is increased in STAT3 deficient mouse embryonic fibroblasts and the IFN $\gamma$-mediated STAT3 activation is enhanced in STAT1 deficient mice highlighting the significance of the balance between STAT1 and STAT3 (116, 117). The processes described above suggest that the STATs are important participants in the maintenance of normal host defence reactions and mechanisms.

The complex role of STAT1 in immune regulation is apparent from animal studies showing that both $\mathrm{STAT}^{-/-}$and IFN $\gamma^{-/-}$mice are highly susceptible to experimental autoimmune encephalomyelitis (EAE) $(118,119)$. It has been demonstrated that in both multiple sclerosis (MS) and in the EAE model $\alpha 5$ integrin and FN could be responsible for the extensive vascular remodelling, characteristic for MS, that takes place during the presymptomatic phase in EAE (120). The regulatory connection between STAT1 and FN described in this paper may explain the more severe disease manifestation in STAT1 ${ }^{-/}$animals. STAT1 has diverse functions, it inhibits a wide range of genes and it is a functional transcription factor even in the absence of inducer-mediated activation. Among its major targets of negative regulation are genes encoding proteins involved in regulating the extracellular matrix: matrix metalloproteinases (MMPs), perlecan, bullosus phemphigoid antigen-1 (BPAG1)(121). Abnormalities in STAT1 level or activity has been linked to several pathological conditions $i$. e. STAT1 is activated in SLE and considered to be a major contributor to SLE-associated inflammation (122).

As our results indicate, in normal homeostatic skin tissue a steady state of STAT1 activation is present and this could be partially responsible for downregulating $\mathrm{FN}$ and $\mathrm{EDA}^{+} \mathrm{FN}$ production, since blocking STAT1 in normal fibroblasts results in enhanced production of FN and $\mathrm{EDA}^{+} \mathrm{FN}$. We detected the absent suppressive function of STAT1 in psoriatic fibroblasts that could be crucial in the pathomechanism of psoriasis. Using a STAT1 decoy oligodeoxynucleotide (dODN)-containing ointment Wagner et al. were able to inhibit hapteninduced contact hypersensitivity reaction in animal models, indicating that topical STAT1 blockade could be a novel anti-inflammatory therapy in skin inflammation (123). Our data indicate that in psoriasis STAT1 inactivation characterizes the uninvolved skin, thus this type of therapy may well work as a symptomatic therapy for the lesional skin. These results may 
help to design new specific therapeutic agents for the treatment of psoriasis that may be more effective and longer lasting in reducing symptoms of the disease, thereby improve the life conditions of psoriatic patients. STAT mutational analysis may have a place in future disease management. The application of STAT inhibitors in inflammatory diseases may have a great potential for future therapies.

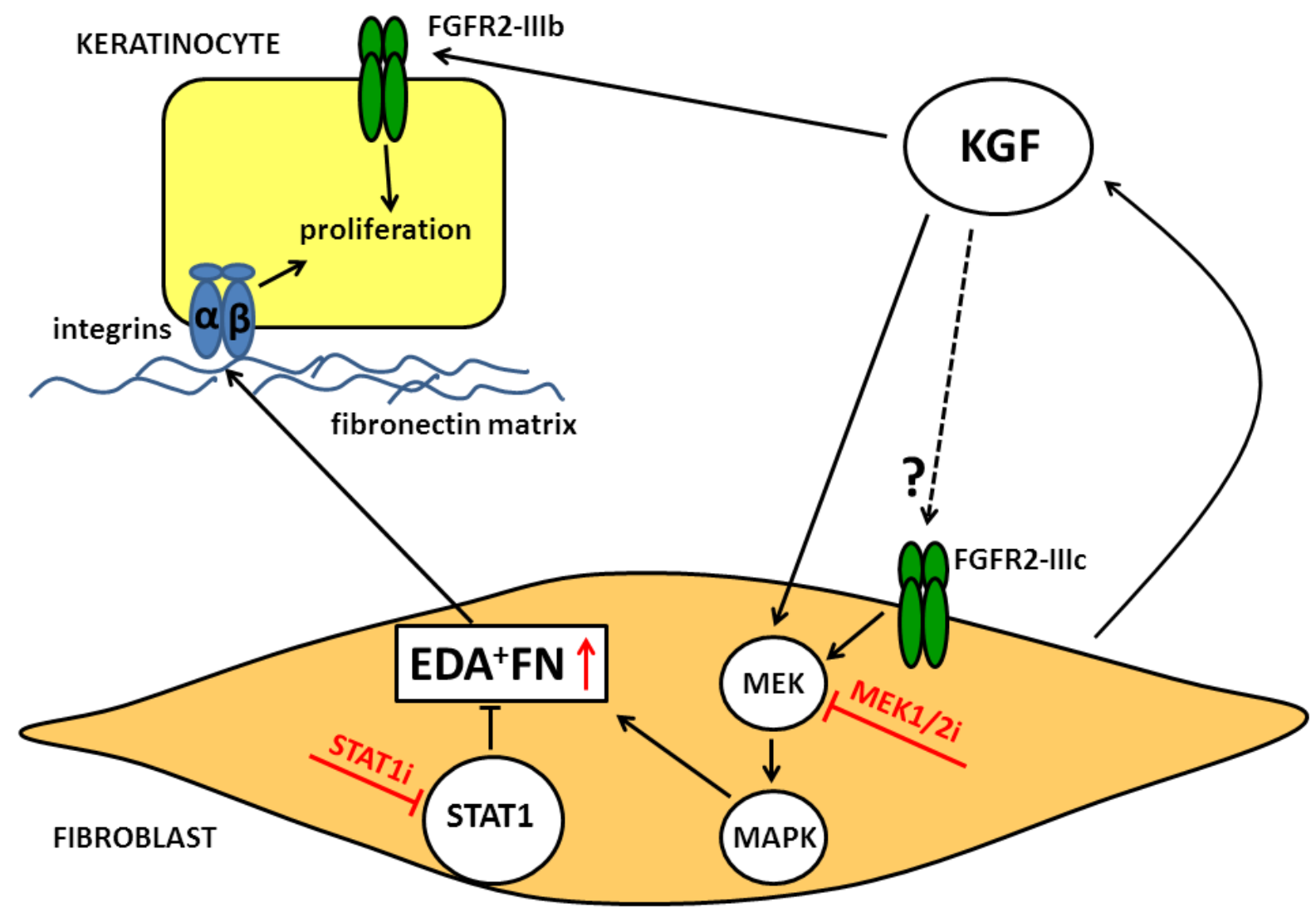

Figure 17. Schematic model of investigated molecules playing a role in KGF mediated $\mathrm{EDA}^{+} \mathrm{FN}$ production in healthy skin. 


\section{ACKNOWLEDGEMENT}

I would like to thank to Prof. Dr. Lajos Kemény for the opportunity to participate in their Ph.D. program and to perform these studies in the laboratory of the Department of Dermatology and Allergology, University of Szeged.

I would also like to express my sincere gratitude to my mentor Prof. Dr. Zsuzsanna Bata-Csörgő at the Department of Dermatology and Allergology, MTA-SZTE Dermatological Research Group, University of Szeged for her supervision of this work and for her constant support, advice and inspiration during my Ph.D. studies.

It also gives me a great pleasure to acknowledge the support and help of Dr. Attila Bebes and Dr. Gergely Groma for their excellent suggestions, new ideas and invaluable advice.

I am thankful to Dr. Máté Manczinger, Éva Viharosné Dósa who helped with the statistical analysis supporting my results.

I am most grateful to Mónika Kohajda for her continuous, tireless assistance and I am also thankful to Dr. Róbert Kui and Róbertné Függ for collecting psoriatic patients and for the preparation of the biological samples.

I am grateful to my colleagues Krisztina Vas, Szabolcs Hambalkó, Zsanett Balog, Zsuzsanna Palotás for introducing me to all the research techniques and for their caring support, help during my work in the laboratory of Department of Dermatology and Allergology, University of Szeged.

I owe a large debt of gratitude to Prof. Dr. Wim Declercq for the opportunity that I could participate in laboratory internships in VIB-UGent Department of Biomedical Molecular Biology, Inflammation Research Center, University of Ghent.

I am thankful to all of my colleagues for their help in the preparative work and for having had the opportunity to work with them.

This study was supported by OTKA K83277, K105985, K111885, NK105369 and by the European Union and the State of Hungary, co-financed by the European Social Fund in the framework of TÁMOP-4.2.4.A/2-11-1/2012-0001.

Last, but not least I am also very grateful to all members of my family who helped me with their endless love, patience, support and encouragement. 


\section{SUMMARY}

In psoriasis the NL skin already contains abnormalities that are likely to serve as a microenvironment favouring the manifestation of the disease. FN and its splice variant the $\mathrm{EDA}^{+} \mathrm{FN}$ are essential extracellular matrix proteins influencing major cellular processes and they are abnormally expressed in psoriatic skin. KGF is overexpressed in psoriatic lesional skin and contribute to keratinocyte hyperproliferation. Given their function, these molecules are likely to play a part in the pathomechanism of psoriasis, therefore, in this study we focused on investigating the production of KGF, FGFR2, FN and $\mathrm{EDA}^{+} \mathrm{FN}$ in healthy and $\mathrm{NL}$ psoriatic skin and studied the regulatory mechanisms involving $\mathrm{KGF}, \mathrm{FN}$ and $\mathrm{EDA}^{+} \mathrm{FN}$ in fibroblasts.

We observed that the psoriatic NL skin displays an overexpression of KGF, FGFR2, $\alpha_{5}$ integrin and $\mathrm{EDA}^{+} \mathrm{FN}$ compared to healthy skin. KGF mildly induced only $\mathrm{EDA}^{+} \mathrm{FN}$, but not FN expression in healthy fibroblasts. Our results revealed that $\mathrm{KGF}$ regulated $\mathrm{EDA}^{+} \mathrm{FN}$ production takes place in an autocrine manner through MAPK signaling. Based on these results we designed an in silico model to predict key players in a putative regulatory network explaining the effect of KGF on $\mathrm{EDA}^{+} \mathrm{FN}$ production. We provide in vitro evidence that STAT1 negatively regulates both $\mathrm{FN}$ and $\mathrm{EDA}^{+} \mathrm{FN}$ expressions in healthy fibroblasts and this regulation is compromised in fibroblasts derived from NL psoriatic dermis. We detected active STAT1 in healthy and lesional skin, as reported previously, however, in the NL skin STAT1 activation was close to absent in samples irrespectively from the distance from lesions.

These result led us to the conclusion that the production of FN, EDA ${ }^{+} \mathrm{FN}$ by fibroblasts and the signaling of STAT1 is abnormally regulated in the psoriatic NL skin, suggesting a crucial mechanism for keeping NL skin in a preactivated state for developing a chronic wound healing phenotype. 


\section{REFERENCES}

1. Harden, J. L., Krueger, J. G., and Bowcock, A. M. (2015) The immunogenetics of Psoriasis: A comprehensive review. J Autoimmun 64, 66-73

2. Baliwag, J., Barnes, D. H., and Johnston, A. (2015) Cytokines in psoriasis. Cytokine 73, 342-350

3. Kim, J., and Krueger, J. G. (2015) The immunopathogenesis of psoriasis. Dermatol Clin 33, 1323

4. Elder, J. T. (2006) PSORS1: linking genetics and immunology. J Invest Dermato/ 126, 12051206

5. Setta-Kaffetzi, N., Simpson, M. A., Navarini, A. A., Patel, V. M., Lu, H. C., Allen, M. H., Duckworth, M., Bachelez, H., Burden, A. D., Choon, S. E., Griffiths, C. E., Kirby, B., Kolios, A., Seyger, M. M., Prins, C., Smahi, A., Trembath, R. C., Fraternali, F., Smith, C. H., Barker, J. N., and Capon, F. (2014) AP1S3 mutations are associated with pustular psoriasis and impaired Toll-like receptor 3 trafficking. American journal of human genetics 94, 790-797

6. Gudjonsson, J. E., Thorarinsson, A. M., Sigurgeirsson, B., Kristinsson, K. G., and Valdimarsson, H. (2003) Streptococcal throat infections and exacerbation of chronic plaque psoriasis: a prospective study. The British journal of dermatology 149, 530-534

7. Johnston, A., Gudjonsson, J. E., Sigmundsdottir, H., Love, T. J., and Valdimarsson, H. (2004) Peripheral blood T cell responses to keratin peptides that share sequences with streptococcal M proteins are largely restricted to skin-homing CD8(+) T cells. Clin Exp Immunol 138, 83-93

8. Seville, R. H. (1977) Psoriasis and stress. The British journal of dermatology 97, 297-302

9. Harvima, R. J., Viinamaki, H., Harvima, I. T., Naukkarinen, A., Savolainen, L., Aalto, M. L., and Horsmanheimo, M. (1996) Association of psychic stress with clinical severity and symptoms of psoriatic patients. Acta Derm Venereol 76, 467-471

10. Weiss, G., Shemer, A., and Trau, H. (2002) The Koebner phenomenon: review of the literature. J Eur Acad Dermatol Venereol 16, 241-248

11. Farber, E. M., and Nall, M. L. (1974) The natural history of psoriasis in 5,600 patients. Dermatologica 148, 1-18

12. Wolters, M. (2005) Diet and psoriasis: experimental data and clinical evidence. The British journal of dermatology 153, 706-714

13. Poikolainen, K., Reunala, T., and Karvonen, J. (1994) Smoking, alcohol and life events related to psoriasis among women. The British journal of dermatology 130, 473-477

14. Elder, J. T., Nair, R. P., Henseler, T., Jenisch, S., Stuart, P., Chia, N., Christophers, E., and Voorhees, J. J. (2001) The genetics of psoriasis 2001: the odyssey continues. Arch Dermatol 137, 1447-1454

15. O'Brien, R. L., and Born, W. K. (2015) Dermal gammadelta T cells--What have we learned? Cell Immunol 296, 62-69

16. Bos, J. D., de Rie, M. A., Teunissen, M. B., and Piskin, G. (2005) Psoriasis: dysregulation of innate immunity. The British journal of dermatology 152, 1098-1107

17. Pellegrini, G., De Luca, M., Orecchia, G., Balzac, F., Cremona, O., Savoia, P., Cancedda, R., and Marchisio, P. C. (1992) Expression, topography, and function of integrin receptors are severely altered in keratinocytes from involved and uninvolved psoriatic skin. J Clin Invest 89, 1783-1795

18. Bata-Csorgo, Z., Cooper, K. D., Ting, K. M., Voorhees, J. J., and Hammerberg, C. (1998) Fibronectin and alpha5 integrin regulate keratinocyte cell cycling. A mechanism for increased fibronectin potentiation of T cell lymphokine-driven keratinocyte hyperproliferation in psoriasis. J Clin Invest 101, 1509-1518 
19. Carroll, J. M., Romero, M. R., and Watt, F. M. (1995) Suprabasal integrin expression in the epidermis of transgenic mice results in developmental defects and a phenotype resembling psoriasis. Cell 83, 957-968

20. Ting, K. M., Rothaupt, D., McCormick, T. S., Hammerberg, C., Chen, G., Gilliam, A. C., Stevens, S., Culp, L., and Cooper, K. D. (2000) Overexpression of the oncofetal Fn variant containing the EDA splice-in segment in the dermal-epidermal junction of psoriatic uninvolved skin. $J$ Invest Dermatol 114, 706-711

21. White, E. S., Baralle, F. E., and Muro, A. F. (2008) New insights into form and function of fibronectin splice variants. J Pathol 216, 1-14

22. Shinde, A. V., Kelsh, R., Peters, J. H., Sekiguchi, K., Van De Water, L., and McKeown-Longo, P. J. (2015) The alpha4beta1 integrin and the EDA domain of fibronectin regulate a profibrotic phenotype in dermal fibroblasts. Matrix Biol 41, 26-35

23. Di Cesare, P. E., Chen, F. S., Moergelin, M., Carlson, C. S., Leslie, M. P., Perris, R., and Fang, C. (2002) Matrix-matrix interaction of cartilage oligomeric matrix protein and fibronectin.

Matrix Biol 21, 461-470

24. Wierzbicka-Patynowski, I., and Schwarzbauer, J. E. (2003) The ins and outs of fibronectin matrix assembly. J Cell Sci 116, 3269-3276

25. Peleg, O., Savin, T., Kolmakov, G. V., Salib, I. G., Balazs, A. C., Kroger, M., and Vogel, V. (2012) Fibers with integrated mechanochemical switches: minimalistic design principles derived from fibronectin. Biophys J 103, 1909-1918

26. Petersen, T. E., Thogersen, H. C., Skorstengaard, K., Vibe-Pedersen, K., Sahl, P., SottrupJensen, L., and Magnusson, S. (1983) Partial primary structure of bovine plasma fibronectin: three types of internal homology. Proceedings of the National Academy of Sciences of the United States of America 80, 137-141

27. Mardon, H. J., Sebastio, G., and Baralle, F. E. (1987) A role for exon sequences in alternative splicing of the human fibronectin gene. Nucleic Acids Res 15, 7725-7733

28. Buratti, E., Muro, A. F., Giombi, M., Gherbassi, D., laconcig, A., and Baralle, F. E. (2004) RNA folding affects the recruitment of SR proteins by mouse and human polypurinic enhancer elements in the fibronectin EDA exon. Molecular and cellular biology 24, 1387-1400

29. Ffrench-Constant, C., Van de Water, L., Dvorak, H. F., and Hynes, R. O. (1989) Reappearance of an embryonic pattern of fibronectin splicing during wound healing in the adult rat. J Cell Biol 109, 903-914

30. Okamura, Y., Watari, M., Jerud, E. S., Young, D. W., Ishizaka, S. T., Rose, J., Chow, J. C., and Strauss, J. F., 3rd. (2001) The extra domain A of fibronectin activates Toll-like receptor 4. The Journal of biological chemistry 276, 10229-10233

31. Manabe, R., Oh-e, N., and Sekiguchi, K. (1999) Alternatively spliced EDA segment regulates fibronectin-dependent cell cycle progression and mitogenic signal transduction. The Journal of biological chemistry 274, 5919-5924

32. Szell, M., Bata-Csorgo, Z., Koreck, A., Pivarcsi, A., Polyanka, H., Szeg, C., Gaal, M., Dobozy, A., and Kemeny, L. (2004) Proliferating keratinocytes are putative sources of the psoriasis susceptibility-related EDA+ (extra domain A of fibronectin) oncofetal fibronectin. J Invest Dermatol 123, 537-546

33. Kornblihtt, A. R., Pesce, C. G., Alonso, C. R., Cramer, P., Srebrow, A., Werbajh, S., and Muro, A. F. (1996) The fibronectin gene as a model for splicing and transcription studies. FASEB J 10, 248-257

34. Saito, S., Yamaji, N., Yasunaga, K., Saito, T., Matsumoto, S., Katoh, M., Kobayashi, S., and Masuho, Y. (1999) The fibronectin extra domain A activates matrix metalloproteinase gene 
expression by an interleukin-1-dependent mechanism. The Journal of biological chemistry 274, 30756-30763

35. You, R., Zheng, M., and McKeown-Longo, P. J. (2010) The first type III repeat in fibronectin activates an inflammatory pathway in dermal fibroblasts. The Journal of biological chemistry 285, 36255-36259

36. Kelsh, R., You, R., Horzempa, C., Zheng, M., and McKeown-Longo, P. J. (2014) Regulation of the innate immune response by fibronectin: synergism between the III-1 and EDA domains. PloS one 9, e102974

37. Ornitz, D. M., Xu, J., Colvin, J. S., McEwen, D. G., MacArthur, C. A., Coulier, F., Gao, G., and Goldfarb, M. (1996) Receptor specificity of the fibroblast growth factor family. The Journal of biological chemistry 271, 15292-15297

38. Turner, N., and Grose, R. (2010) Fibroblast growth factor signalling: from development to cancer. Nat Rev Cancer 10, 116-129

39. Powers, C. J., McLeskey, S. W., and Wellstein, A. (2000) Fibroblast growth factors, their receptors and signaling. Endocr Relat Cancer 7, 165-197

40. Guo, L., Yu, Q. C., and Fuchs, E. (1993) Targeting expression of keratinocyte growth factor to keratinocytes elicits striking changes in epithelial differentiation in transgenic mice. EMBO J 12, 973-986

41. Krueger, G. G., and Jorgensen, C. M. (1990) Experimental models for psoriasis. J Invest Dermatol 95, 56S-58S

42. Andreadis, S. T., Hamoen, K. E., Yarmush, M. L., and Morgan, J. R. (2001) Keratinocyte growth factor induces hyperproliferation and delays differentiation in a skin equivalent model system. FASEB J 15, 898-906

43. Zhang, X., Ibrahimi, O. A., Olsen, S. K., Umemori, H., Mohammadi, M., and Ornitz, D. M. (2006) Receptor specificity of the fibroblast growth factor family. The complete mammalian FGF family. The Journal of biological chemistry 281, 15694-15700

44. Eswarakumar, V. P., Lax, I., and Schlessinger, J. (2005) Cellular signaling by fibroblast growth factor receptors. Cytokine Growth Factor Rev 16, 139-149

45. Miki, T., Bottaro, D. P., Fleming, T. P., Smith, C. L., Burgess, W. H., Chan, A. M., and Aaronson, S. A. (1992) Determination of ligand-binding specificity by alternative splicing: two distinct growth factor receptors encoded by a single gene. Proceedings of the National Academy of Sciences of the United States of America 89, 246-250

46. Johnson, R. L., Rothman, A. L., Xie, J., Goodrich, L. V., Bare, J. W., Bonifas, J. M., Quinn, A. G., Myers, R. M., Cox, D. R., Epstein, E. H., Jr., and Scott, M. P. (1996) Human homolog of patched, a candidate gene for the basal cell nevus syndrome. Science 272, 1668-1671

47. Alarid, E. T., Rubin, J. S., Young, P., Chedid, M., Ron, D., Aaronson, S. A., and Cunha, G. R. (1994) Keratinocyte growth factor functions in epithelial induction during seminal vesicle development. Proceedings of the National Academy of Sciences of the United States of America 91, 1074-1078

48. Muhr, P., Zeitvogel, J., Heitland, I., Werfel, T., and Wittmann, M. (2011) Expression of interleukin (IL)-1 family members upon stimulation with IL-17 differs in keratinocytes derived from patients with psoriasis and healthy donors. The British journal of dermatology 165, 189193

49. Luo, Y., Ye, S., Kan, M., and McKeehan, W. L. (2006) Control of fibroblast growth factor (FGF) 7- and FGF1-induced mitogenesis and downstream signaling by distinct heparin octasaccharide motifs. The Journal of biological chemistry 281, 21052-21061

50. Bottcher, R. T., and Niehrs, C. (2005) Fibroblast growth factor signaling during early vertebrate development. Endocr Rev 26, 63-77 
51. Werner, S. (1998) Keratinocyte growth factor: a unique player in epithelial repair processes. Cytokine Growth Factor Rev 9, 153-165

52. Spielberger, R., Stiff, P., Bensinger, W., Gentile, T., Weisdorf, D., Kewalramani, T., Shea, T., Yanovich, S., Hansen, K., Noga, S., McCarty, J., LeMaistre, C. F., Sung, E. C., Blazar, B. R., Elhardt, D., Chen, M. G., and Emmanouilides, C. (2004) Palifermin for oral mucositis after intensive therapy for hematologic cancers. N Engl J Med 351, 2590-2598

53. Qiao, J., Uzzo, R., Obara-Ishihara, T., Degenstein, L., Fuchs, E., and Herzlinger, D. (1999) FGF-7 modulates ureteric bud growth and nephron number in the developing kidney. Development 126, 547-554

54. Ichimura, T., Finch, P. W., Zhang, G., Kan, M., and Stevens, J. L. (1996) Induction of FGF-7 after kidney damage: a possible paracrine mechanism for tubule repair. Am J Physiol 271, F967-976

55. Grose, R., and Dickson, C. (2005) Fibroblast growth factor signaling in tumorigenesis. Cytokine Growth Factor Rev 16, 179-186

56. De Moerlooze, L., Spencer-Dene, B., Revest, J. M., Hajihosseini, M., Rosewell, I., and Dickson, C. (2000) An important role for the IIIb isoform of fibroblast growth factor receptor 2 (FGFR2) in mesenchymal-epithelial signalling during mouse organogenesis. Development $127,483-$ 492

57. Yu, K., Herr, A. B., Waksman, G., and Ornitz, D. M. (2000) Loss of fibroblast growth factor receptor 2 ligand-binding specificity in Apert syndrome. Proceedings of the National Academy of Sciences of the United States of America 97, 14536-14541

58. Chen, H., Ma, J., Li, W., Eliseenkova, A. V., Xu, C., Neubert, T. A., Miller, W. T., and Mohammadi, M. (2007) A molecular brake in the kinase hinge region regulates the activity of receptor tyrosine kinases. Mol Cell 27, 717-730

59. Katoh, M. (2009) FGFR2 abnormalities underlie a spectrum of bone, skin, and cancer pathologies. J Invest Dermatol 129, 1861-1867

60. O'Shea, J. J., Gadina, M., and Kanno, Y. (2011) Cytokine signaling: birth of a pathway. Journal of immunology $187,5475-5478$

61. Ihle, J. N. (1995) Cytokine receptor signalling. Nature 377, 591-594

62. Villarino, A. V., Kanno, Y., Ferdinand, J. R., and O'Shea, J. J. (2015) Mechanisms of Jak/STAT signaling in immunity and disease. Journal of immunology 194, 21-27

63. Ghoreschi, K., and Gadina, M. (2014) Jakpot! New small molecules in autoimmune and inflammatory diseases. Exp Dermatol 23, 7-11

64. Sikorski, K., Chmielewski, S., Olejnik, A., Wesoly, J. Z., Heemann, U., Baumann, M., and Bluyssen, H. (2012) STAT1 as a central mediator of IFNgamma and TLR4 signal integration in vascular dysfunction. Jak-Stat 1, 241-249

65. Hu, X., and Ivashkiv, L. B. (2009) Cross-regulation of signaling pathways by interferon-gamma: implications for immune responses and autoimmune diseases. Immunity 31, 539-550

66. Sikorski, K., Chmielewski, S., Przybyl, L., Heemann, U., Wesoly, J., Baumann, M., and Bluyssen, H. A. (2011) STAT1-mediated signal integration between IFNgamma and LPS leads to increased EC and SMC activation and monocyte adhesion. Am J Physiol Cell Physiol 300, C1337-1344

67. Liu, J., and Ma, X. (2006) Interferon regulatory factor 8 regulates RANTES gene transcription in cooperation with interferon regulatory factor-1, NF-kappaB, and PU.1. The Journal of biological chemistry 281, 19188-19195

68. Schroder, K., Sweet, M. J., and Hume, D. A. (2006) Signal integration between IFNgamma and TLR signalling pathways in macrophages. Immunobiology 211, 511-524 
69. Zhao, J., Kong, H. J., Li, H., Huang, B., Yang, M., Zhu, C., Bogunovic, M., Zheng, F., Mayer, L., Ozato, K., Unkeless, J., and Xiong, H. (2006) IRF-8/interferon (IFN) consensus sequencebinding protein is involved in Toll-like receptor (TLR) signaling and contributes to the crosstalk between TLR and IFN-gamma signaling pathways. The Journal of biological chemistry 281, 10073-10080

70. Nishio, H., Matsui, K., Tsuji, H., Tamura, A., and Suzuki, K. (2001) Immunolocalisation of the janus kinases (JAK)--signal transducers and activators of transcription (STAT) pathway in human epidermis. J Anat 198, 581-589

71. Mortarini, R., Vegetti, C., Molla, A., Arienti, F., Ravagnani, F., Maurichi, A., Patuzzo, R., Santinami, M., and Anichini, A. (2009) Impaired STAT phosphorylation in T cells from melanoma patients in response to IL-2: association with clinical stage. Clin Cancer Res 15, 4085-4094

72. Bernabei, P., Coccia, E. M., Rigamonti, L., Bosticardo, M., Forni, G., Pestka, S., Krause, C. D., Battistini, A., and Novelli, F. (2001) Interferon-gamma receptor 2 expression as the deciding factor in human T, B, and myeloid cell proliferation or death. Journal of leukocyte biology 70 , 950-960

73. O'Shea, J. J., Holland, S. M., and Staudt, L. M. (2013) JAKs and STATs in immunity, immunodeficiency, and cancer. N Engl J Med 368, 161-170

74. Casanova, J. L., Holland, S. M., and Notarangelo, L. D. (2012) Inborn errors of human JAKs and STATs. Immunity 36, 515-528

75. Fry, L., Baker, B. S., Powles, A. V., Fahlen, A., and Engstrand, L. (2013) Is chronic plaque psoriasis triggered by microbiota in the skin? The British journal of dermatology 169, 47-52

76. McFadden, J., Fry, L., Powles, A. V., and Kimber, I. (2012) Concepts in psoriasis: psoriasis and the extracellular matrix. The British journal of dermatology 167, 980-986

77. Bata-Csorgo, Z., Hammerberg, C., Voorhees, J. J., and Cooper, K. D. (1995) Kinetics and regulation of human keratinocyte stem cell growth in short-term primary ex vivo culture. Cooperative growth factors from psoriatic lesional T lymphocytes stimulate proliferation among psoriatic uninvolved, but not normal, stem keratinocytes. J Clin Invest 95, 317-327

78. Kormos, B., Belso, N., Bebes, A., Szabad, G., Bacsa, S., Szell, M., Kemeny, L., and Bata-Csorgo, Z. (2011) In vitro dedifferentiation of melanocytes from adult epidermis. PloS one 6, e17197

79. Uzan, B., Figeac, F., Portha, B., and Movassat, J. (2009) Mechanisms of KGF mediated signaling in pancreatic duct cell proliferation and differentiation. PloS one 4, e4734

80. Cichon, A. C., Pickard, A., McDade, S. S., Sharpe, D. J., Moran, M., James, J. A., and McCance, D. J. (2013) AKT in stromal fibroblasts controls invasion of epithelial cells. Oncotarget 4, 1103-1116

81. Huang, R., Faratian, D., Sims, A. H., Wilson, D., Thomas, J. S., Harrison, D. J., and Langdon, S. P. (2014) Increased STAT1 signaling in endocrine-resistant breast cancer. PloS one 9, e94226

82. Khan, M. M., Gandhi, C., Chauhan, N., Stevens, J. W., Motto, D. G., Lentz, S. R., and Chauhan, A. K. (2012) Alternatively-spliced extra domain A of fibronectin promotes acute inflammation and brain injury after cerebral ischemia in mice. Stroke 43, 1376-1382

83. D'Amici, S., Ceccarelli, S., Vescarelli, E., Romano, F., Frati, L., Marchese, C., and Angeloni, A. (2013) TNFalpha modulates Fibroblast Growth Factor Receptor 2 gene expression through the PRB/E2F1 pathway: identification of a non-canonical E2F binding motif. PloS one 8, e61491

84. Bourquin, J. P., Stagljar, I., Meier, P., Moosmann, P., Silke, J., Baechi, T., Georgiev, O., and Schaffner, W. (1997) A serine/arginine-rich nuclear matrix cyclophilin interacts with the Cterminal domain of RNA polymerase II. Nucleic Acids Res 25, 2055-2061 
85. Finch, P. W., Murphy, F., Cardinale, I., and Krueger, J. G. (1997) Altered expression of keratinocyte growth factor and its receptor in psoriasis. Am J Pathol 151, 1619-1628

86. Kovacs, D., Falchi, M., Cardinali, G., Raffa, S., Carducci, M., Cota, C., Amantea, A., Torrisi, M. R., and Picardo, M. (2005) Immunohistochemical analysis of keratinocyte growth factor and fibroblast growth factor 10 expression in psoriasis. Exp Dermatol 14, 130-137

87. Haimes, E. (1993) Issues of gender in gamete donation. Soc Sci Med 36, 85-93

88. Tang, A., and Gilchrest, B. A. (1996) Regulation of keratinocyte growth factor gene expression in human skin fibroblasts. J Dermatol Sci 11, 41-50

89. Maas-Szabowski, N., Shimotoyodome, A., and Fusenig, N. E. (1999) Keratinocyte growth regulation in fibroblast cocultures via a double paracrine mechanism. J Cell Sci 112 ( Pt 12), 1843-1853

90. Szabowski, A., Maas-Szabowski, N., Andrecht, S., Kolbus, A., Schorpp-Kistner, M., Fusenig, N. E., and Angel, P. (2000) c-Jun and JunB antagonistically control cytokine-regulated mesenchymal-epidermal interaction in skin. Cell 103, 745-755

91. Xu, N., Brodin, P., Wei, T., Meisgen, F., Eidsmo, L., Nagy, N., Kemeny, L., Stahle, M., Sonkoly, E., and Pivarcsi, A. (2011) MiR-125b, a microRNA downregulated in psoriasis, modulates keratinocyte proliferation by targeting FGFR2. J Invest Dermatol 131, 1521-1529

92. Avraamides, C. J., Garmy-Susini, B., and Varner, J. A. (2008) Integrins in angiogenesis and lymphangiogenesis. Nat Rev Cancer 8, 604-617

93. Mondello, M. R., Magaudda, L., Pergolizzi, S., Santoro, A., Vaccaro, M., Califano, L., Cannavo, S. P., and Guarneri, B. (1996) Behaviour of laminin 1 and type IV collagen in uninvolved psoriatic skin. Immunohistochemical study using confocal laser scanning microscopy. Archives of dermatological research 288, 527-531

94. Vaccaro, M., Magaudda, L., Cutroneo, G., Trimarchi, F., Barbuzza, O., Guarneri, F., and Guarneri, B. (2002) Changes in the distribution of laminin alpha1 chain in psoriatic skin: immunohistochemical study using confocal laser scanning microscopy. The British journal of dermatology 146, 392-398

95. Sandig, H., McDonald, J., Gilmour, J., Arno, M., Lee, T. H., and Cousins, D. J. (2009) Fibronectin is a TH1-specific molecule in human subjects. J Allergy Clin Immunol 124, 528535, 535 e521-525

96. Kanayama, M., Morimoto, J., Matsui, Y., Ikesue, M., Danzaki, K., Kurotaki, D., Ito, K., Yoshida, T., and Uede, T. (2011) alpha9beta1 integrin-mediated signaling serves as an intrinsic regulator of pathogenic Th17 cell generation. Journal of immunology 187, 5851-5864

97. Brown, W. S., Khalili, J. S., Rodriguez-Cruz, T. G., Lizee, G., and Mclntyre, B. W. (2014) B-Raf regulation of integrin alpha4beta1-mediated resistance to shear stress through changes in cell spreading and cytoskeletal association in T cells. The Journal of biological chemistry $\mathbf{2 8 9}$, 23141-23153

98. Gondokaryono, S. P., Ushio, H., Niyonsaba, F., Hara, M., Takenaka, H., Jayawardana, S. T., Ikeda, S., Okumura, K., and Ogawa, H. (2007) The extra domain A of fibronectin stimulates murine mast cells via toll-like receptor 4. Journal of leukocyte biology 82, 657-665

99. Lasarte, J. J., Casares, N., Gorraiz, M., Hervas-Stubbs, S., Arribillaga, L., Mansilla, C., Durantez, M., Llopiz, D., Sarobe, P., Borras-Cuesta, F., Prieto, J., and Leclerc, C. (2007) The extra domain A from fibronectin targets antigens to TLR4-expressing cells and induces cytotoxic $T$ cell responses in vivo. Journal of immunology 178, 748-756

100. Groves, R. W., Allen, M. H., Ross, E. L., Barker, J. N., and MacDonald, D. M. (1995) Tumour necrosis factor alpha is pro-inflammatory in normal human skin and modulates cutaneous adhesion molecule expression. The British journal of dermatology 132, 345-352 
101. Shlyankevich, J., Mehta, N. N., Krueger, J. G., Strober, B., Gudjonsson, J. E., Qureshi, A. A., Tebbey, P. W., and Kimball, A. B. (2014) Accumulating evidence for the association and shared pathogenic mechanisms between psoriasis and cardiovascular-related comorbidities.

Am J Med 127, 1148-1153

102. McFadden, J. P., Baker, B. S., Powles, A. V., and Fry, L. (2010) Psoriasis and extra domain A fibronectin loops. The British journal of dermatology 163, 5-11

103. Blaustein, M., Pelisch, F., Coso, O. A., Bissell, M. J., Kornblihtt, A. R., and Srebrow, A. (2004) Mammary epithelial-mesenchymal interaction regulates fibronectin alternative splicing via phosphatidylinositol 3-kinase. The Journal of biological chemistry 279, 21029-21037

104. Baelde, H. J., Eikmans, M., van Vliet, A. I., Bergijk, E. C., de Heer, E., and Bruijn, J. A. (2004) Alternatively spliced isoforms of fibronectin in immune-mediated glomerulosclerosis: the role of TGFbeta and IL-4. J Pathol 204, 248-257

105. Strutz, F., Zeisberg, M., Hemmerlein, B., Sattler, B., Hummel, K., Becker, V., and Muller, G. A. (2000) Basic fibroblast growth factor expression is increased in human renal fibrogenesis and may mediate autocrine fibroblast proliferation. Kidney Int 57, 1521-1538

106. Murakami, M., Elfenbein, A., and Simons, M. (2008) Non-canonical fibroblast growth factor signalling in angiogenesis. Cardiovasc Res 78, 223-231

107. Jarvelainen, H., Sainio, A., Koulu, M., Wight, T. N., and Penttinen, R. (2009) Extracellular matrix molecules: potential targets in pharmacotherapy. Pharmacol Rev 61, 198-223

108. Luu, K., Greenhill, C. J., Majoros, A., Decker, T., Jenkins, B. J., and Mansell, A. (2014) STAT1 plays a role in TLR signal transduction and inflammatory responses. Immunol Cell Biol 92, 761-769

109. Madonna, S., Scarponi, C., Sestito, R., Pallotta, S., Cavani, A., and Albanesi, C. (2010) The IFNgamma-dependent suppressor of cytokine signaling 1 promoter activity is positively regulated by IFN regulatory factor-1 and Sp1 but repressed by growth factor independence$1 \mathrm{~b}$ and Kruppel-like factor-4, and it is dysregulated in psoriatic keratinocytes. Journal of immunology 185, 2467-2481

110. McKenzie, R. C., and Sabin, E. (2003) Aberrant signalling and transcription factor activation as an explanation for the defective growth control and differentiation of keratinocytes in psoriasis: a hypothesis. Exp Dermatol 12, 337-345

111. Yoshimura, A., Suzuki, M., Sakaguchi, R., Hanada, T., and Yasukawa, H. (2012) SOCS, Inflammation, and Autoimmunity. Front Immunol 3, 20

112. Takahashi, R., Nishimoto, S., Muto, G., Sekiya, T., Tamiya, T., Kimura, A., Morita, R., Asakawa, M., Chinen, T., and Yoshimura, A. (2011) SOCS1 is essential for regulatory T cell functions by preventing loss of Foxp3 expression as well as IFN-\{gamma\} and IL-17A production. J Exp Med 208, 2055-2067

113. Bromberg, J., and Darnell, J. E., Jr. (2000) The role of STATs in transcriptional control and their impact on cellular function. Oncogene 19, 2468-2473

114. Sutherland, A. P., Joller, N., Michaud, M., Liu, S. M., Kuchroo, V. K., and Grusby, M. J. (2013) IL-21 promotes CD8+ CTL activity via the transcription factor T-bet. Journal of immunology 190, 3977-3984

115. Gelebart, P., Zak, Z., Anand, M., Dien-Bard, J., Amin, H. M., and Lai, R. (2009) Interleukin-21 effectively induces apoptosis in mantle cell lymphoma through a STAT1-dependent mechanism. Leukemia 23, 1836-1846

116. Qing, Y., and Stark, G. R. (2004) Alternative activation of STAT1 and STAT3 in response to interferon-gamma. The Journal of biological chemistry 279, 41679-41685

117. Costa-Pereira, A. P., Tininini, S., Strobl, B., Alonzi, T., Schlaak, J. F., Is'harc, H., Gesualdo, I., Newman, S. J., Kerr, I. M., and Poli, V. (2002) Mutational switch of an IL-6 response to an 
interferon-gamma-like response. Proceedings of the National Academy of Sciences of the United States of America 99, 8043-8047

118. Bettelli, E., Sullivan, B., Szabo, S. J., Sobel, R. A., Glimcher, L. H., and Kuchroo, V. K. (2004) Loss of T-bet, but not STAT1, prevents the development of experimental autoimmune encephalomyelitis. J Exp Med 200, 79-87

119. Prinz, M., Schmidt, H., Mildner, A., Knobeloch, K. P., Hanisch, U. K., Raasch, J., Merkler, D., Detje, C., Gutcher, I., Mages, J., Lang, R., Martin, R., Gold, R., Becher, B., Bruck, W., and Kalinke, U. (2008) Distinct and nonredundant in vivo functions of IFNAR on myeloid cells limit autoimmunity in the central nervous system. Immunity 28, 675-686

120. Boroujerdi, A., Welser-Alves, J. V., and Milner, R. (2013) Extensive vascular remodeling in the spinal cord of pre-symptomatic experimental autoimmune encephalomyelitis mice; increased vessel expression of fibronectin and the alpha5beta1 integrin. Exp Neurol 250, 43 51

121. Ramana, C. V., Chatterjee-Kishore, M., Nguyen, H., and Stark, G. R. (2000) Complex roles of Stat1 in regulating gene expression. Oncogene 19, 2619-2627

122. Rauch, I., Muller, M., and Decker, T. (2013) The regulation of inflammation by interferons and their STATs. Jak-Stat 2, e23820

123. Wagner, A. H., Wittjen, I., Stojanovic, T., Middel, P., Meingassner, J. G., and Hecker, M. (2008) Signal transducer and activator of transcription 1 decoy oligodeoxynucleotide suppression of contact hypersensitivity. J Allergy Clin Immunol 121, 158-165 e155 


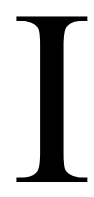




\section{Abnormal regulation of fibronectin production by fibroblasts in psoriasis}

B. Gubán, ${ }^{1}$ K. Vas, ${ }^{1}$ Z. Balog, ${ }^{1}$ M. Manczinger, ${ }^{1}$ A. Bebes, ${ }^{1}$ G. Groma, ${ }^{2}$ M. Széll, ${ }^{2,3}$ L. Kemény ${ }^{1,2}$ and Z. Bata-Csörgö ${ }^{1,2}$

${ }^{1}$ Department of Dermatology and Allergology, ${ }^{2}$ MTA-SZTE Dermatological Research Group and ${ }^{3}$ Department of Medical Genetics, University of Szeged, Korányi fasor 6, H-6720 Szeged, Hungary

Linked Comment: Pongpairoj and McFadden, Br J Dermatol 2016; 174: 486

\section{Summary}

\section{Correspondence}

Barbara Gubán

E-mail: gubanbarbi@gmail.com

\section{Accepted for publication}

5 October 2015

\section{Funding sources}

This study was supported by OTKA grants K83277, K105985, K111885, NK105369 and PD116992 and by the European Union and the State of Hungary, cofinanced by the European Social Fund in the framework of TÁMOP4.2.4.A/2-11-1/2012-0001 'National Excellence Program’ A2-SZGYA-FOK-13-0001.

Conflicts of interest

None declared.

DOI 10.1111/bjd.14219
Background Data indicate that in psoriasis, abnormalities are already present in nonlesional skin. Transforming growth factor- $\beta$ and keratinocyte growth factor (KGF), together with fibronectin and $\alpha 5 \beta 1$ integrin, were suggested to play a crucial role in the pathogenesis of psoriasis by influencing inflammation and keratinocyte hyperproliferation.

Objectives To investigate the expression of KGF, fibroblast growth factor receptor (FGFR)2, fibronectin (FN) and extra domain A (EDA)-positive FN in healthy and nonlesional psoriatic skin, and to study the effect of KGF on the regulation of FN and $\mathrm{EDA}^{+} \mathrm{FN}$ production by fibroblasts.

Methods Healthy, nonlesional psoriatic skin and lesional psoriatic skin were immunostained for $\alpha 5$ integrin, KGF, FGFR2, EDA ${ }^{+} \mathrm{FN}$ and signal transducer and activator of transcription (STAT)1. KGF-treated cell cultures were analysed for FN and $\mathrm{EDA}^{+} \mathrm{FN}$ mRNA and protein by real-time reverse-transcriptase polymerase chain reaction and flow cytometry, respectively. The major downstream signalling of KGF was investigated by blocking experiments using inhibitors of mitogen-activated protein kinase (MAPK) kinase (MEK1), AKT1/2, STAT1 and STAT3.

Results The expression of $\alpha 5$ integrin, $\mathrm{EDA}^{+} \mathrm{FN}, \mathrm{KGF}$ and its receptor FGFR2 is elevated in psoriatic nonlesional skin compared with healthy skin. KGF mildly induced $\mathrm{EDA}^{+} \mathrm{FN}$, but not FN expression in healthy fibroblasts through MAPK signalling. Fibroblasts express the FGFR2-IIIc splice variant. STAT1 negatively regulates both FN and $\mathrm{EDA}^{+} \mathrm{FN}$ expression in healthy fibroblasts, and this regulation is compromised in fibroblasts derived from nonlesional psoriatic dermis. We detected active STAT1 in healthy and lesional skin, similarly to a previous report. However, in the nonlesional skin STAT1 activation was absent in tissues far away from lesions.

Conclusions The production of FN and $\mathrm{EDA}^{+} \mathrm{FN}$ by fibroblasts and the signalling of STAT1 are abnormally regulated in psoriatic nonlesional skin.

\section{What's already known about this topic?}

- In psoriasis, nonlesional skin already contains abnormalities as a base for the manifestation of the disease.

- Fibronectin (FN) and its splice variant $\mathrm{EDA}^{+} \mathrm{FN}$ are essential extracellular matrix proteins influencing major cellular processes, and they are abnormally expressed in psoriatic skin.

- Keratinocyte growth factor (KGF) is overexpressed in psoriatic lesional skin and contributes to keratinocyte hyperproliferation. 


\section{What does this study add?}

- KGF and its receptor FGFR2 are overexpressed in psoriatic nonlesional skin. KGF influences $\mathrm{EDA}^{+} \mathrm{FN}$ production in fibroblasts through MEK1 signalling.

- Fibroblasts express the FGFR2-IIIc splice variant of the FGFR2 receptor.

- STAT1 negatively regulates $\mathrm{FN}$ and $\mathrm{EDA}^{+} \mathrm{FN}$ production in normal cultured fibroblasts, but not in fibroblasts derived from psoriatic nonlesional skin.

- STAT1 is active in healthy skin and psoriatic lesional skin, but not in nonlesional psoriatic skin.

It is well known that psoriasis is an inflammatory skin disease in which both innate and adaptive immune activation play an essential role in the maintenance of the abnormal skin phenotype. ${ }^{1}$ However, it is less well known how much resident cells of the tissue contribute to the pathology. A reasonable approach to seek alterations in tissue responses in psoriasis is to investigate the phenotypically normal-looking nonlesional psoriatic skin.

The main fibronectin (FN) receptor $\alpha_{5} \beta_{1}$ integrin was found to be overexpressed in nonlesional psoriatic epidermis compared with normal skin. ${ }^{2,3}$ There is evidence that proper regulation of integrin expression in keratinocytes is essential for normal epidermal homeostasis, as shown by the suprabasal overexpression of integrins in transgenic mice resulting in epidermal hyperproliferation and inflammatory reaction. ${ }^{4}$ In the steady state of normal human adult epidermis, $\alpha_{5}$ integrin expression of keratinocytes is downregulated. A possible explanation for $\alpha_{5}$ integrin overexpression in nonlesional skin is the presence of FN and one of its isoforms, extra domain A-containing fibronectin $\left(\mathrm{EDA}^{+} \mathrm{FN}\right)$, in the microenvironment of basal keratinocytes. ${ }^{3,5}$

Keratinocyte growth factor (KGF/FGF7) is a member of the fibroblast growth factor (FGF) family produced by mesenchymal cells and considered to be a major growth factor for keratinocytes. Several reports suggest that KGF reduces the ability of keratinocytes to initiate terminal differentiation and undergo programmed cell death. Overexpression of KGF in the basal epidermal cell layer of transgenic mice results in epidermal hyperplasia. ${ }^{6}$ There is also evidence suggesting that fibroblasts from lesional and nonlesional skin of patients with psoriasis induce keratinocyte outgrowth by producing soluble signals. ${ }^{7}$ More recently, it has been reported that KGF can induce the expression of $\alpha_{5}$ integrin, and it delays the expression of keratin 10 and transglutaminase in keratinocytes. ${ }^{8}$ Indirect evidence, such as measurement of mitogenic activity, suggests that the specific receptor for KGF on epithelial cells is the IIIb splice variant of fibroblast growth factor receptor (FGFR) 2. ${ }^{9}$

According to our observations, psoriatic nonlesional skin displays a marked overexpression of KGF, FGFR2, $\alpha_{5}$ integrin and $\mathrm{EDA}^{+} \mathrm{FN}$ compared with healthy skin. Therefore, in this study we focused on investigating regulatory mechanisms involving KGF and FN. Our results revealed that KGF regulates $\mathrm{EDA}^{+} \mathrm{FN}$ production in an autocrine manner through mitogen-activated protein kinase (MAPK) signalling in healthy fibroblasts. With these results we designed an in silico model to predict a possible regulatory network for the effect of KGF on $\mathrm{EDA}^{+} \mathrm{FN}$ production. We provide in vitro evidence that both $\mathrm{FN}$ and $\mathrm{EDA}^{+} \mathrm{FN}$ are negatively regulated by activated signal transducer and activator of transcription (STAT) 1 in healthy fibro-blasts, and this is in contrast to psoriatic nonlesional skin-derived fibroblasts. Active, phosphorylated STAT1 was found in healthy skin as well as in psoriatic lesions, but not in psoriatic nonlesional skin, suggesting a crucial mechanism for keeping nonlesional skin in a preactivated state to developing a chronic wound-healing phenotype.

\section{Materials and methods}

\section{Skin biopsies}

Patients with moderate-to-severe chronic plaque-type psoriasis and healthy volunteers (age 18-60 years) were enrolled into the study. Patients had a medication-free period of $\geq 4$ weeks without systemic therapy and/or $\geq 2$ weeks without local therapy. Participant-informed consent was obtained prior to surgical intervention. The Psoriasis Area and Severity Index (PASI) score was determined for all patients by dermatologists. Samples were collected from 16 patients and 25 healthy volunteers for the experiments. Mechanical stress was induced by a tape-stripping procedure, then punch biopsies were taken from uninvolved skin of patients with psoriasis $(n=6)$ and healthy subjects $(n=6)$ from a tape-stripped and nontreated (control) skin area from the buttock area at 24 and $48 \mathrm{~h}$ after treatment (Fig. S1). For all other experiments, tissues without the introduction of mechanical stress were used. All tissue collection complied with the guidelines of the Declaration of Helsinki and was approved by the Regional and Institutional Research Ethics Committee (2799, 3517).

\section{Immunofluorescence staining}

Human punch biopsies were frozen embedded, stored at $-80{ }^{\circ} \mathrm{C}$, then cut into $6-\mu \mathrm{m}$ sections. Samples were fixed in Fixation/Permeabilization Concentrate and Diluent (eBioscience, San Diego, CA, U.S.A.) and resuspended in phosphate-buffered saline (PBS). The sections were incubated for $30 \mathrm{~min}$ in goat serum (Sigma-Aldrich, St Louis, MO, U.S.A.). The following primary antibodies were used, overnight at $4{ }^{\circ} \mathrm{C}$ : FGFR2 [1 : 100, Bek (C-17); Santa Cruz Biotechnology, Santa Cruz, CA, U.S.A.], KGF [1 : 500, FGF-7 (N-14); Santa Cruz Biotechnology], $\alpha_{5}$ integrin (1: 200; Becton-Dickinson, Franklin Lakes, NJ, U.S.A.), $\mathrm{EDA}^{+} \mathrm{FN}$ (1 : 500, clone IST9; Abcam, Cambridge, U.K.) and pSTAT1 (Ser727) and p-STAT1 (Tyr701) (both 1 : 400; Cell Signaling Technology, Beverly, MA, U.S.A.). Goat antirabbit IgG- 
Alexa Fluor 488, donkey antigoat IgG-Alexa Fluor 546, goat antimouse IgG-Alexa Fluor 647 and Alexa Fluor 546 were used as secondary antibodies (all 1 : 500; Life Technologies, Carlsbad, CA, U.S.A.) for $2 \mathrm{~h}$ at room temperature. Sections were incubated without the primary antibody or with isotype control antibody for negative staining controls. Nuclei were stained with DAPI (4', 6-diamidino-2-phenylindole; Sigma-Aldrich).

Cultured human fibroblasts, keratinocytes and $\mathrm{HaCaT}$ cells were collected after brief trypsinization ( $0 \cdot 25 \%$ trypsin solution; Sigma-Aldrich) and centrifuged onto a slide using a cytocentrifuge $\left(\right.$ Cytopro $^{\mathrm{TM}}$; Wescor, Logan, UT, U.S.A.), then fixed in $2 \%$ paraformaldehyde (Sigma-Aldrich). Stainings were carried out as described above. Images were documented with a Zeiss AxioImager Z1 fluorescence microscope (Carl Zeiss Microscopy GmbH, Munich, Germany) equipped with an AxioCam MRm camera. Image processing and data analysis were conducted using ZEN 2012 Microscope and Imaging (Carl Zeiss) or ImageJ software (http://imagej.nih.gov/ij/).

\section{Flow cytometry}

Cells were harvested as described above, fixed in Fixation/Permeabilization Concentrate and Diluent (eBioscience) and resuspended in PBS. Primary antibodies anti-EDA ${ }^{+}$FN ( 1 : 500, clone IST9; Abcam) and anti-FN (1:1000, clone IST4; Sigma-Aldrich) were applied for $45 \mathrm{~min}$. Mouse IgG1 isotype antibody (Sigma-Aldrich) was used as the negative control. Cells were then washed in PBS and incubated with secondary antibodies as described above. Samples were analysed on a FACSCalibur flow cytometer equipped with 488$\mathrm{mm}$ and 633-nm lasers (Becton-Dickinson).

\section{Statistical analysis}

For statistical analysis, repeated-measures Friedman ANOvA, Wilcoxon test or one-way ANOva were used. Multiple comparisons were carried out with SigmaPlot software (Systat Software Inc., Chicago, IL, U.S.A.). A probability test was used to test for normality; $\mathrm{P} \leq 0.05$ was considered significant.

\section{Further methods}

Detailed information of the materials and methods regarding cell culture experiments, real-time quantitative reverse-transcriptase polymerase chain reaction (RT-PCR) and the in silico model are presented in Appendix S1 (see Supporting Information).

\section{Results}

\section{Altered protein expression of $\alpha_{5}$ integrin, extra domain A-positive fibronectin, keratinocyte growth factor and fibroblast growth factor receptor 2 in psoriatic nonlesional skin}

Healthy skin and psoriatic nonlesional skin were investigated for differences in the expression of $\alpha_{5}$ integrin, $\mathrm{EDA}^{+} \mathrm{FN}$,
KGF and FGFR2 before and 24 and $48 \mathrm{~h}$ after tape stripping. Immunofluorescence staining revealed a striking difference in all protein expressions examined, even without tape stripping, between normal and psoriatic nonlesional skin (Fig. 1). Mild mechanical stress introduced by tape stripping of the skin did not lead to any obvious changes in $\alpha_{5}$ integrin, $\mathrm{EDA}^{+} \mathrm{FN}, \mathrm{KGF}$ or FGFR2 expression or distribution at 24 and $48 \mathrm{~h}$ after treatment in nonlesional skin. In healthy control sections a slight increase in all protein expression was observed based on immunostaining (Fig. S1a-d).

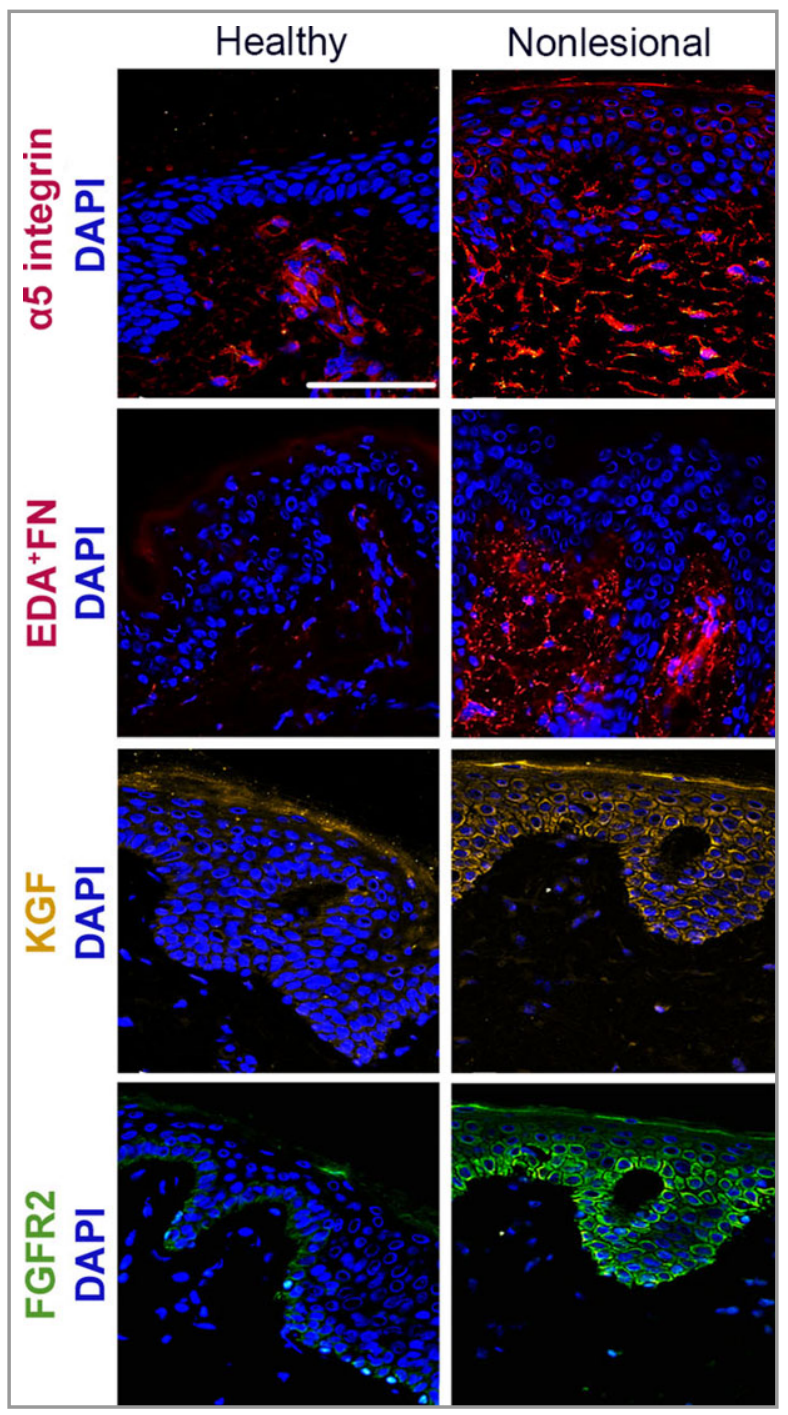

Fig 1. Increased expression of $\alpha_{5}$ integrin, extra domain A-containing fibronectin $\left(\mathrm{EDA}^{+} \mathrm{FN}\right)$, keratinocyte growth factor (KGF) and fibroblast growth factor receptor (FGFR)2 in nonlesional skin without mechanical stress stimuli. Immunofluorescence analysis of $\alpha_{5}$ integrin, $\mathrm{EDA}^{+} \mathrm{FN}, \mathrm{KGF}$ and FGFR2 in healthy (left column) and nonlesional skin (right column) $(n=6)$. DAPI, 4',6-diamidino-2-phenylindole. Bar: $50 \mu \mathrm{m}$. 


\section{Keratinocyte growth factor treatment of healthy human fibroblasts leads to the elevation of extra domain A-positive fibronectin production}

$\mathrm{EDA}^{+} \mathrm{FN}$ and KGF are known to stimulate keratinocyte proliferation. KGF induces the expression of the major FN cell surface receptor $\alpha_{5} \beta_{1}$ integrin. Given the differences in $\mathrm{EDA}^{+} \mathrm{FN}$ and KGF protein levels in healthy and nonlesional psoriatic skin, we set out to investigate a putative regulatory connection between these two molecules. Exogenous treatment of cultured healthy fibroblasts with KGF for $24 \mathrm{~h}$ increased the level of the $\mathrm{EDA}^{+} \mathrm{FN}$ splice variant, but not the total FN protein, based on immunostaining and flow cytometry measurements (Fig. 2a, b). A similar increase in the $\mathrm{EDA}^{+} \mathrm{FN}$ mRNA splice variant was detected, while the total FN mRNA remained unchanged (Fig. 2c).

We also investigated this effect of KGF on normal human keratinocytes and melanocytes and on the keratinocyte cell line, HaCaT (Figs S2, S3). As expected, keratinocytes and $\mathrm{HaCaT}$ cells expressed $\mathrm{FN}$ and $\mathrm{EDA}^{+} \mathrm{FN}$ at a very low level compared with fibroblasts, while melanocytes expressed both proteins at a comparable level with fibroblasts (Fig. S3). However, upon in vitro KGF treatment these cells did not display detectable changes in mRNA and protein expression of $\mathrm{EDA}^{+} \mathrm{FN}$ and total FN (Fig. S2).

\section{Expression of fibroblast growth factor receptor 2 splice variants in fibroblasts, melanocytes and keratinocytes}

Two splice variants have been identified for FGFR2, designated as FGFR2-IIIb and FGFR2-IIIc, which have different ligandbinding preferences. These results were based on mitotic activity measurements. ${ }^{10}$ KGF has been shown to act on the FGFR2-IIIb variant, increasing cellular proliferation. ${ }^{11}$ We determined the expression of the splice variants on healthy fibroblasts, melanocytes and keratinocytes using specific primers designed for RT-PCR, revealing that melanocytes and keratinocytes expressed FGFR2-IIIb only, while fibroblasts expressed mainly the FGFR2-IIIc variant (Fig. 3).

\section{Mitogen-activated protein kinase signalling is involved in the regulation of extra domain A-positive fibronectin by keratinocyte growth factor receptor in healthy fibroblasts}

Fibroblast growth factor signals (including KGF) are coordinated by four major pathways: Ras-Raf-MAPK, phos-

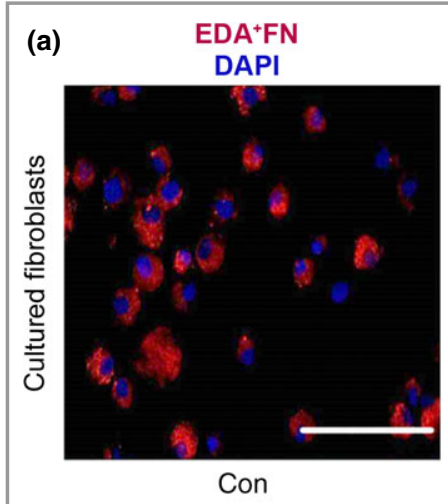

(b)
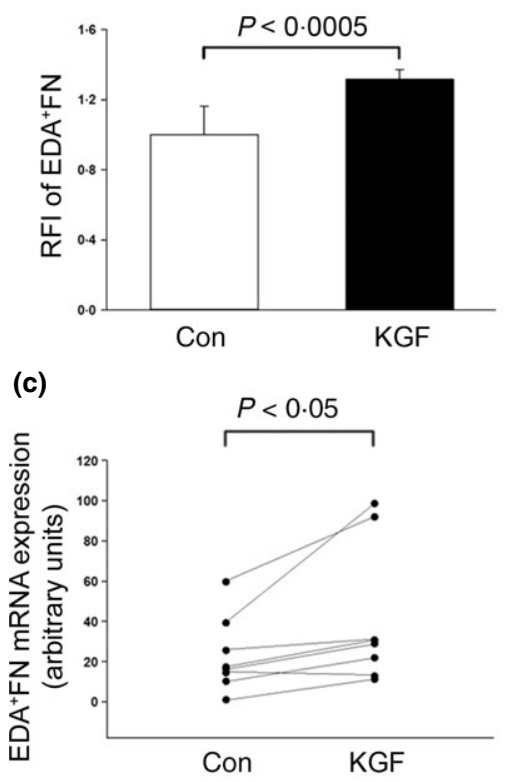

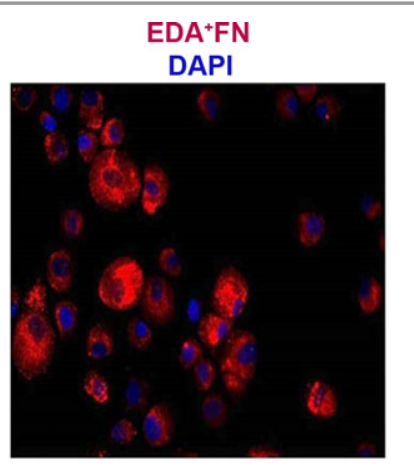

KGF
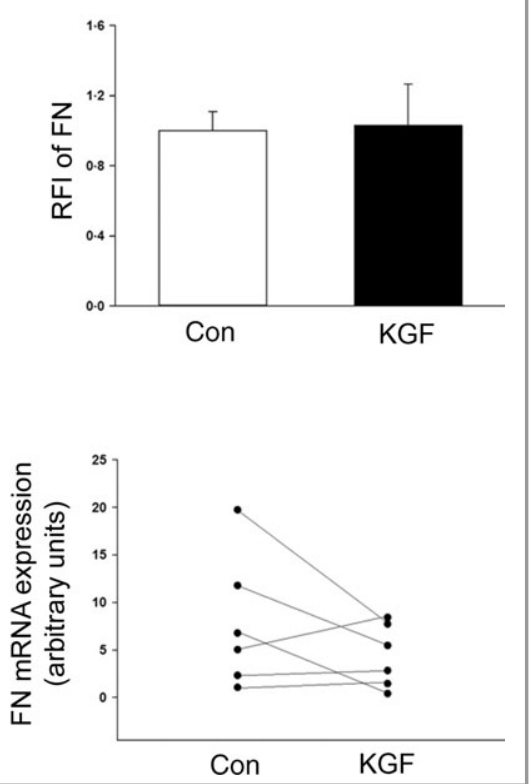

Fig 2. The expression of extra domain Acontaining fibronectin $\left(\mathrm{EDA}^{+} \mathrm{FN}\right)$ is induced by keratinocyte growth factor (KGF) in normal human fibroblasts. KGF-treated fibroblasts and the change in expression in fibronectin (FN) and $\mathrm{EDA}^{+} \mathrm{FN}$ at $24 \mathrm{~h}$. (a) Immunofluorescent detection of $\mathrm{EDA}^{+} \mathrm{FN}$. (b) Flow cytometry measurement of $\mathrm{EDA}^{+} \mathrm{FN}$ and FN levels following KGF treatment. RFI, relative fluorescence intensity; con, control. (c) FN and $\mathrm{EDA}^{+} \mathrm{FN}$ mRNA expression following KGF stimulation. Values are expressed in arbitrary units. Data represent the mean \pm SEM $(n=6)$. DAPI, 4',6-diamidino2-phenylindole. Bar: $50 \mu \mathrm{m}$. 


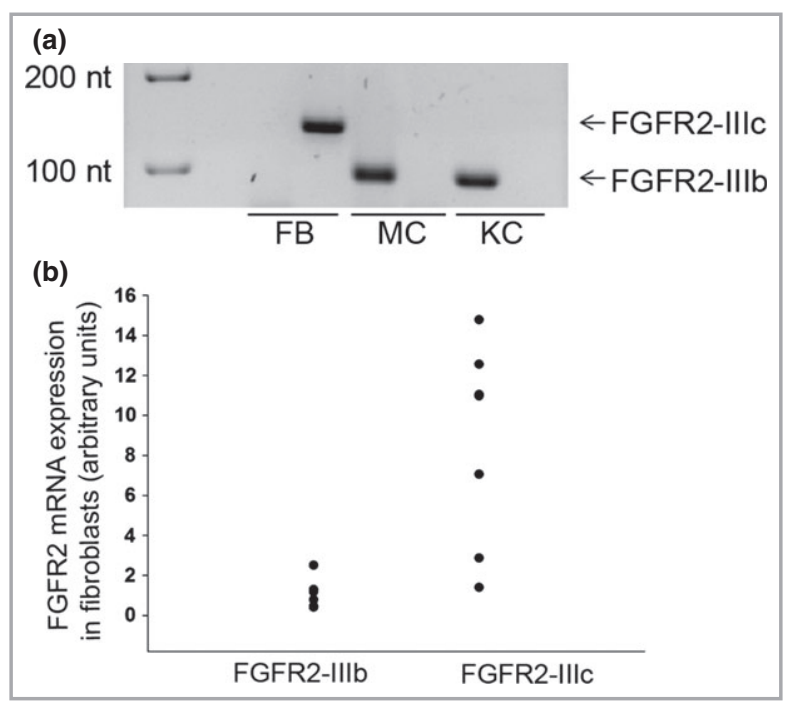

Fig 3. Human fibroblasts in culture express mainly fibroblast growth factor receptor (FGFR2)-IIIc, while melanocytes and keratinocytes express the FGFR2-IIIb splice variant of FGFR2. (a) Reversetranscriptase polymerase chain reaction (RT-PCR) products specific for FGFR2-IIIb and IIIc were run on a 2\% agarose gel of cultured human fibroblasts (FB), melanocytes (MC) and keratinocytes (KC). (b) FGFR2 mRNA expression by fibroblasts for the two investigated splice variants detected by real-time RT-PCR. Values are expressed in arbitrary units.

phoinositide 3-kinase (PI3K)/Akt, STAT and phospholipase $\mathrm{C} \gamma \cdot{ }^{12,13}$ In order to get a better insight into the modulation of FN expression by KGF in cultured fibroblasts derived from healthy skin, we performed blocking experiments targeting key molecules of the signal transduction pathways using specific inhibitors available for MAPK kinase (MEK1) (MAPK pathway), Akt1/2 (PI3K-Akt pathway), STAT1 and STAT3 (STAT pathway) either alone or in combination. After $24 \mathrm{~h}$ of inhibitory treatment the expression of $\mathrm{FN}$ and $\mathrm{EDA}^{+} \mathrm{FN}$ was determined by flow cytometry and RT-PCR. The KGF-induced $\mathrm{EDA}^{+} \mathrm{FN}$ elevation was abolished by the inhibition of MEK1 and returned to the level of control fibroblasts (Fig. 4a). In contrast, blocking Akt1/2 did not have an effect on EDA ${ }^{+}$FN protein expression (Fig. S4). The inhibition of STAT1 or STAT3 did not influence KGF-mediated changes in $\mathrm{EDA}^{+} \mathrm{FN}$ levels (Fig. 4b). However, impairing these signalling molecules resulted in a KGF-independent elevation of both FN and $\mathrm{EDA}^{+} \mathrm{FN}$ protein levels that was significant in the case of STAT1 inhibition (Fig. 4c).

\section{Abnormal signal transducer and activator of transcription 1 activation in psoriatic skin plays a role in the regulation of both fibronectin and extra domain A-positive fibronectin}

To investigate further, we compared the $\mathrm{FN}$ and $\mathrm{EDA}^{+} \mathrm{FN}$ expressions between healthy and psoriatic nonlesional skinderived fibroblasts $24 \mathrm{~h}$ after STAT1 or STAT3 inhibition in culture. Changes upon STAT3 impairment were not significant; however, blockade of STAT1 did not lead to the elevation of total $\mathrm{FN}$ and $\mathrm{EDA}^{+} \mathrm{FN}$ in fibroblasts from nonlesional skin in contrast to healthy controls (Fig. 4c). Therefore, we investigated the phosphorylation pattern of STAT1 at Tyr701 and Ser727, which are known to be key amino acid modifications leading to dimerization and influencing activity.

Immunofluorescent staining for the phosphorylated Ser727 was highest in lesional psoriatic skin, and lower, but clearly detectable, in healthy skin, whereas nonlesional skin samples showed the lowest intensity. In two of four investigated nonlesional samples phosphorylation was undetectable (Fig. 4d). Staining for the phosphorylated Tyr701 showed a much less noticeable but similar pattern. In samples of patients where no serine phosphorylation was detected in the nonlesional skin, staining for the phosphorylated Tyr701 was also not visible in either nonlesional or lesional areas. To elucidate whether differences observed in STAT1 activity among patients correlated with the severity of the disease, PASI scores of donor patients were compared. The patients whose nonlesional skin was negative for phosphorylations of STAT1 had lower PASI scores (12.4 and 17.8), therefore we were able to take nonlesional samples further away from lesions, at least 10 -cm distance. Patients with detectable but low STAT1 activity in nonlesional skin had higher PASI scores (19.6 and 20).

\section{In silico model construction}

We constructed an in silico model based on our in vitro results involving KGF and FN signalling and the resultant transcriptional regulation network (Fig. 5 and Tables S1, S2). Our data already suggested the participation of MAPK signalling in KGF-induced FN splicing. The generated coexpression matrix implied a potential role of peptidylprolyl cis-trans isomerase G (PPIG), a protein important in both protein folding and splicing, ${ }^{14}$ which is regulated by MEK1-induced activating protein (AP)-1. Changes in MEK1 activity could lead to modulation of FN splicing through PPIG, resulting in elevated $\mathrm{EDA}^{+} \mathrm{FN}$ levels.

Our model also indicates that STAT3 negatively regulates the expression of MEK1. This suggested inhibitory effect of STAT3 on MEK1 may account for the increased EDA ${ }^{+}$FN production upon STAT inhibition. However, our model did not explain our data showing a significant increase in $\mathrm{EDA}^{+} \mathrm{FN}$ and FN following STAT1 inhibition in normal fibroblasts. The schematic summary model of KGF-induced changes on FN based on our results in normal skin (in vivo, in vitro and in silico) is presented in Figure 6.

\section{Discussion}

One of the major characteristics of psoriatic lesional skin is the hyperproliferation of keratinocytes, where KGF is known to play an important role. At the protein level both KGF and FGFR2 were demonstrated to be elevated in lesional skin compared with normal skin. ${ }^{15}$ At the mRNA level in both nonlesional and lesional tissue, increased expression of both KGF 

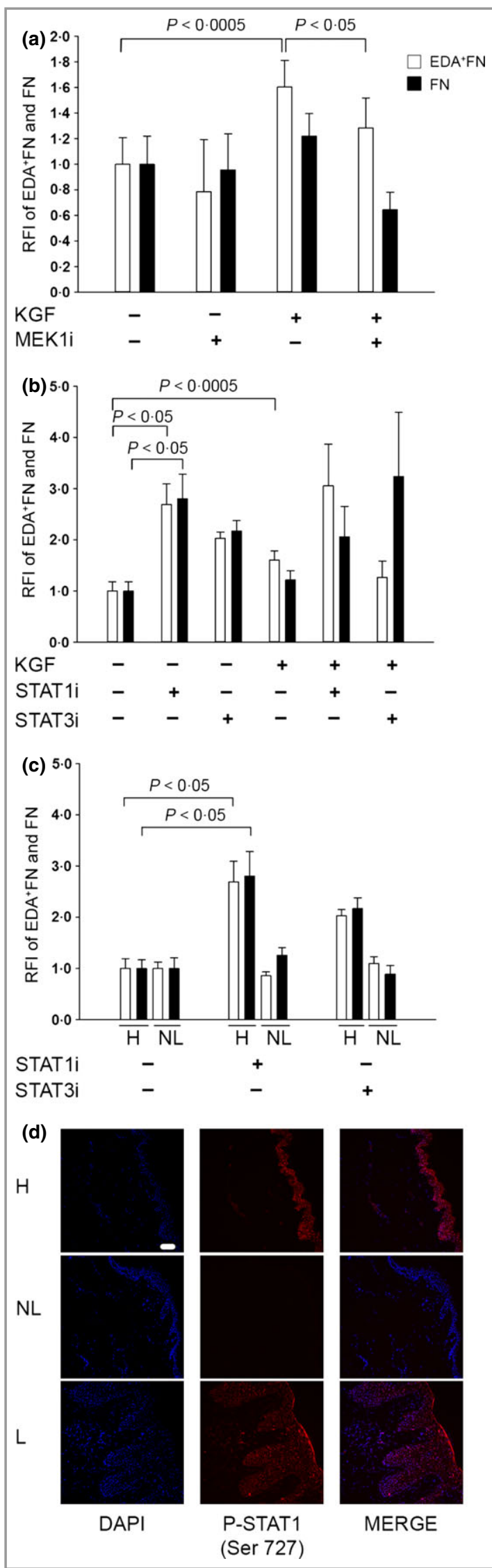

Fig 4. Keratinocyte growth factor (KGF)-influenced elevation of extra domain A-containing fibronectin $\left(\mathrm{EDA}^{+} \mathrm{FN}\right)$, mediated through mitogen-activated protein kinase (MAPK) signalling, and altered signal transducer and activator of transcription (STAT) 1 regulation of $\mathrm{EDA}^{+} \mathrm{FN}$ and fibronectin (FN) expression in psoriasis. (a) FN and $\mathrm{EDA}^{+} \mathrm{FN}$ levels of healthy fibroblasts treated with KGF alone or in combination with a MAPK kinase (MEK1) inhibitor. (b) Following treatment of healthy fibroblasts with KGF alone or in combination with inhibitors of STAT1, STAT3 or both. (c) The effect of STAT1 and STAT3 inhibition on FN and $\mathrm{EDA}^{+} \mathrm{FN}$ in fibroblasts derived from healthy (H) and nonlesional (NL) skin. (d) Immunofluorescent analysis of STAT1 Ser727 phosphorylation. L, lesional skin. Data represent the mean $\pm \operatorname{SEM}(n=6)$. RFI, relative fluorescence intensity; DAPI, 4',6-diamidino-2-phenylindole. Bar: $50 \mu \mathrm{m}$.

and FGFR2 transcripts was also described by others. ${ }^{16,17}$ KGF stimulates keratinocyte proliferation and influences terminal differentiation. ${ }^{6,17}$ The only known source of KGF in the skin is fibroblasts, and keratinocytes can mediate KGF production in fibroblasts through interleukin (IL)-1, ${ }^{18,19}$ establishing a double paracrine regulatory loop, controlled by AP-1 subunits C-Jun and JunB, and directing the regeneration of the epidermis and maintaining tissue homeostasis in the skin. ${ }^{20}$ It was reported that the microRNA miR-125 is downregulated in psoriatic lesional tissue. miR-125 is known to have a negative influence on keratinocyte proliferation, partially by downregulating FGFR2 expression and driving keratinocytes towards differentiation. ${ }^{21}$

Integrins and their corresponding extracellular ligands also influence cell proliferation and differentiation. ${ }^{22}$ Overexpression of $\alpha 5$ integrin and $\mathrm{EDA}^{+} \mathrm{FN}$ has already been reported in connection with psoriasis, and our group demonstrated that one of the potential sources of $\mathrm{EDA}^{+} \mathrm{FN}$ in nonlesional psoriatic skin is activated keratinocytes. ${ }^{23}$ Another report on nonlesional skin has shown that $\mathrm{EDA}^{+} \mathrm{FN}$ was localized mainly at the dermoepidermal junction. ${ }^{5}$ It is well established that $\alpha 5$ integrin and $\mathrm{EDA}^{+} \mathrm{FN}$ could play an important regulatory role in the abnormal epidermal homeostasis of psoriatic skin, ${ }^{3,23}$ and more recent evidence suggests that EDA ${ }^{+} \mathrm{FN}$ could be crucial in activating immune cells. ${ }^{24,25}$ The EDA motif encompasses two nonclassical binding sites for $\alpha_{4} \beta_{1}$ and $\alpha_{9} \beta_{1}$ integrins, ${ }^{26}$ receptors present on the surface of $\mathrm{T}$ cells ${ }^{27,28}$ that could enhance T-cell migration and accumulation in $\mathrm{EDA}^{+} \mathrm{FN}-$ containing tissues, such as the skin.

$\mathrm{EDA}^{+} \mathrm{FN}$ promotes acute inflammation and brain injury following cerebral ischaemia in mice. ${ }^{29} \mathrm{EDA}^{+} \mathrm{FN}$ is normally absent in human plasma; however, patients with chronic inflammation and ischaemic stroke have high plasma EDA ${ }^{+} \mathrm{FN}$. The abnormally regulated overproduction of $\mathrm{EDA}^{+} \mathrm{FN}$ in psoriatic fibroblasts may not only be responsible for maintaining a local chronic inflammation in the skin, but may also influence plasma levels that could play a role in the systemic inflammation that has been reported recently in psoriasis. ${ }^{30}$ The $\mathrm{EDA}^{+}$FN-rich extracellular milieu in psoriatic skin could be 
Fig 5. In silico model of keratinocyte growth factor (KGF) and fibronectin (FN) signalling. Green arrow, positive transcriptional regulation; red arrow with circle arrowhead, negative transcriptional regulation; arrows with dashed lines, undetermined direction of regulation. FGFR, fibroblast growth factor receptor; ITGA, integrin alpha; MEK1, mitogen-activated protein kinase kinase; PPIG, peptidylprolyl cis-trans isomerase G; SDC, syndecan; STAT, signal transducer and activator of transcription.
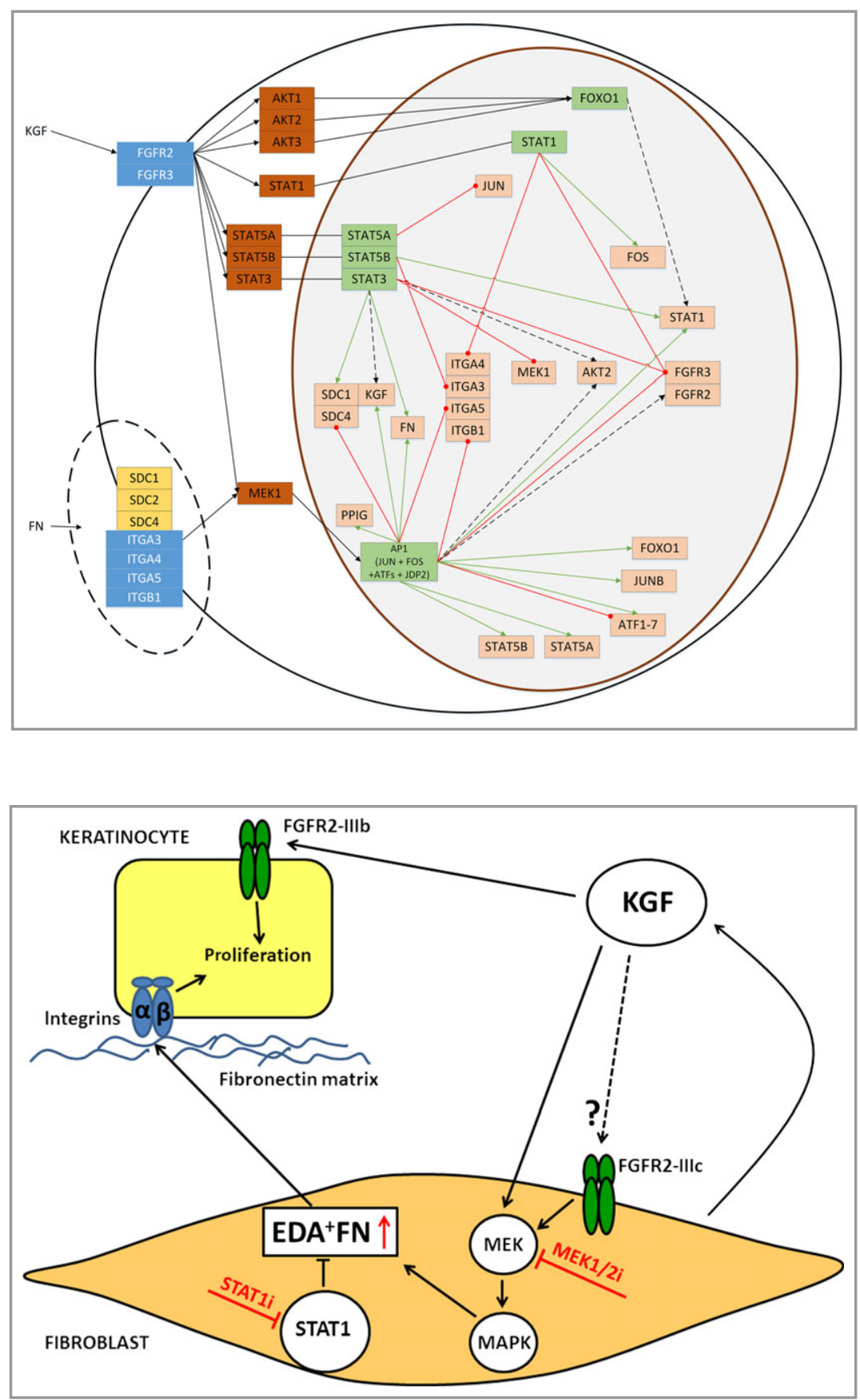

Fig 6. Schematic model of investigated molecules playing a role in keratinocyte growth factor (KGF)-mediated extra domain A-containing fibronectin (EDA $\left.{ }^{+} \mathrm{FN}\right)$ production in healthy skin. FGFR, fibroblast growth factor receptor; MAPK, mitogenactivated protein kinase; MEK, MAPK kinase; STAT, signal transducer and activator of transcription.
KGF exerts its effect mainly through FGFR2-IIIb, but also via FGFR2-IIIc and FGFR1. ${ }^{11}$ As both FGFR2 and FGFR1 can initiate MEK1 signalling, KGF could potentially modulate FN splicing in a similar autocrine manner to other FGFs, most likely either through FGFR2-IIIc or FGFR $1^{10,36}$ in fibroblasts. However, the participation of other unknown receptors also cannot be excluded, and further research is needed to understand the exact mechanism through which KGF affects FN splicing. Directly blocking $\mathrm{EDA}^{+} \mathrm{FN}$ seems less feasible as a therapeutic approach compared with blocking KGF or its receptors. ${ }^{37}$

STAT1 is the founding member of the STAT family and is activated by interferons (IFNs), and signalling from IL-27, IL-35 and Toll-like receptors. ${ }^{38}$ There is ample evidence 
implicating IFN- $\gamma$ in the pathomechanism of psoriasis. ${ }^{39}$ Aberrant signalling and transcription have been reported for psoriatic keratinocytes with regard to SOCS1 (suppressor of cytokine signalling 1), a negative regulator of IFN- $\gamma$ signalling, ${ }^{40}$ and also for STAT1 and interferon-regulated factor $1{ }^{41}$ The complex role of STAT1 in immune regulation is apparent from animal studies showing that both STAT1 ${ }^{-/-}$ and IFN $\gamma^{-/-}$mice are highly susceptible to experimental autoimmune encephalomyelitis (EAE). ${ }^{42,43}$ It has been demonstrated in both multiple sclerosis and in the EAE model that $\alpha 5$ integrin and FN could be responsible for the extensive vascular remodelling, characteristic for MS, that takes place during the presymptomatic phase in EAE. ${ }^{44}$

The regulatory connection between STAT1 and FN described in this article may explain the more severe disease manifestation in $\mathrm{STAT}^{-/-}$animals. STAT1 has diverse functions: it inhibits certain genes and is a functional transcription factor even in the absence of inducer-mediated activation. Among its major targets of negative regulation are genes encoding proteins involved in regulating the extracellular matrix: matrix metalloproteinases, perlecan and bullous pemphigoid antigen-1. ${ }^{45}$ As our results indicate, in normal homeostatic skin tissue, a steady state of STAT1 activation is present, and this could be partially responsible for downregulating FN and $\mathrm{EDA}^{+} \mathrm{FN}$ production, as blocking STAT1 in normal fibroblasts results in enhanced production of FN and $\mathrm{EDA}^{+} \mathrm{FN}$. The absent suppressive function of STAT1 in psoriatic fibroblasts could be crucial in the pathomechanism of psoriasis. Using a STAT1 decoy oligodeoxynucleotide-containing ointment Wagner et al. were able to inhibit hapten-induced contact hypersensitivity reaction in animal models, indicating that topical STAT1 blockade could be a novel anti-inflammatory therapy in skin inflammation. ${ }^{46}$ Our data indicate that in psoriasis STAT1, inactivation characterizes the uninvolved skin; thus, this type of therapy may well work as a symptomatic therapy for lesional skin.

\section{Acknowledgments}

We are thankful to Mónika Kohajda for her assistance and we are also grateful to Róbertné Függ for the preparation of the biological samples.

\section{References}

1 Bos JD, De Rie MA, Teunissen MB, Piskin G. Psoriasis: dysregulation of innate immunity. Br J Dermatol 2005; 152:1098-107.

2 Pellegrini G, De Luca M, Orecchia G et al. Expression, topography, and function of integrin receptors are severely altered in keratinocytes from involved and uninvolved psoriatic skin. J Clin Invest 1992; 89:1783-95.

3 Bata-Csorgo Z, Cooper KD, Ting KM et al. Fibronectin and $\alpha 5$ integrin regulate keratinocyte cell cycling. A mechanism for increased fibronectin potentiation of $\mathrm{T}$ cell lymphokine-driven keratinocyte hyperproliferation in psoriasis. J Clin Invest 1998; 101:1509-18.

4 Carroll JM, Romero MR, Watt FM. Suprabasal integrin expression in the epidermis of transgenic mice results in developmental defects and a phenotype resembling psoriasis. Cell 1995; 83:95768

5 Ting KM, Rothaupt D, McCormick TS et al. Overexpression of the oncofetal Fn variant containing the EDA splice-in segment in the dermal-epidermal junction of psoriatic uninvolved skin. J Invest Dermatol 2000; 114:706-11.

6 Guo L, Yu QC, Fuchs E. Targeting expression of keratinocyte growth factor to keratinocytes elicits striking changes in epithelial differentiation in transgenic mice. EMBO J 1993; 12:973-86.

7 Krueger GG, Jorgensen CM. Experimental models for psoriasis. J Invest Dermatol 1990; 95(5 Suppl.):56S-8S.

8 Andreadis ST, Hamoen KE, Yarmush ML, Morgan JR. Keratinocyte growth factor induces hyperproliferation and delays differentiation in a skin equivalent model system. FASEB J 2001; 15:898-906.

9 Zhang X, Ibrahimi OA, Olsen SK et al. Receptor specificity of the fibroblast growth factor family. The complete mammalian FGF family. J Biol Chem 2006; 281:15694-700.

10 Powers CJ, McLeskey SW, Wellstein A. Fibroblast growth factors, their receptors and signaling. Endocr Relat Cancer 2000; 7:165-97.

11 Ornitz DM, Xu J, Colvin JS et al. Receptor specificity of the fibroblast growth factor family. J Biol Chem 1996; 271:15292-7.

12 Eswarakumar VP, Lax I, Schlessinger J. Cellular signaling by fibroblast growth factor receptors. Cytokine Growth Factor Rev 2005; 16:139-49.

13 Turner N, Grose R. Fibroblast growth factor signalling: from development to cancer. Nat Rev Cancer 2010; 10:116-29.

14 Bourquin JP, Stagljar I, Meier P et al. A serine/arginine-rich nuclear matrix cyclophilin interacts with the C-terminal domain of RNA polymerase II. Nucleic Acids Res 1997; 25:2055-61.

15 Finch PW, Murphy F, Cardinale I, Krueger JG. Altered expression of keratinocyte growth factor and its receptor in psoriasis. Am J Pathol 1997; 151:1619-28.

16 Kovacs D, Falchi M, Cardinali G et al. Immunohistochemical analysis of keratinocyte growth factor and fibroblast growth factor 10 expression in psoriasis. Exp Dermatol 2005; 14:130-7.

17 Haimes E. Issues of gender in gamete donation. Soc Sci Med 1993; 36:85-93.

18 Tang A, Gilchrest BA. Regulation of keratinocyte growth factor gene expression in human skin fibroblasts. J Dermatol Sci 1996; 11:41-50.

19 Maas-Szabowski N, Shimotoyodome A, Fusenig NE. Keratinocyte growth regulation in fibroblast cocultures via a double paracrine mechanism. J Cell Sci 1999; 112:1843-53.

20 Szabowski A, Maas-Szabowski N, Andrecht S et al. c-Jun and JunB antagonistically control cytokine-regulated mesenchymal-epidermal interaction in skin. Cell 2000; 103:745-55.

$21 \mathrm{Xu} \mathrm{N}$, Brodin P, Wei T et al. MiR-125b, a microRNA downregulated in psoriasis, modulates keratinocyte proliferation by targeting FGFR2. J Invest Dermatol 2011; 131:1521-9.

22 Avraamides CJ, Garmy-Susini B, Varner JA. Integrins in angiogenesis and lymphangiogenesis. Nat Rev Cancer 2008; 8:604-17.

23 Szell M, Bata-Csorgo Z, Koreck A et al. Proliferating keratinocytes are putative sources of the psoriasis susceptibility-related EDA+ (extra domain A of fibronectin) oncofetal fibronectin. J Invest Dermatol 2004; 123:537-46.

24 Okamura Y, Watari M, Jerud ES et al. The extra domain A of fibronectin activates Toll-like receptor 4. J Biol Chem 2001; 276:1022933.

25 Sandig H, McDonald J, Gilmour J et al. Fibronectin is a TH1-specific molecule in human subjects. J Allergy Clin Immunol 2009; 124:528-35, 535.e1-5.

26 White ES, Baralle FE, Muro AF. New insights into form and function of fibronectin splice variants. J Pathol 2008; 216:1-14. 
27 Kanayama M, Morimoto J, Matsui Y et al. $\alpha 9 \beta 1$ integrin-mediated signaling serves as an intrinsic regulator of pathogenic Th17 cell generation. J Immunol 2011; 187:5851-4.

28 Brown WS, Khalili JS, Rodriguez-Cruz TG et al. B-Raf regulation of integrin $\alpha 4 \beta 1$-mediated resistance to shear stress through changes in cell spreading and cytoskeletal association in T cells. J Biol Chem 2014; 289:23141-53.

29 Khan MM, Gandhi C, Chauhan N et al. Alternatively-spliced extra domain A of fibronectin promotes acute inflammation and brain injury after cerebral ischemia in mice. Stroke 2012; 43: 1376-82.

30 Shlyankevich J, Mehta NN, Krueger JG et al. Accumulating evidence for the association and shared pathogenic mechanisms between psoriasis and cardiovascular-related comorbidities. Am J Med 2014; 127:1148-53.

31 McFadden JP, Baker BS, Powles AV, Fry L. Psoriasis and extra domain A fibronectin loops. Br J Dermatol 2010; 163:5-11.

32 McFadden J, Fry L, Powles AV, Kimber I. Concepts in psoriasis: psoriasis and the extracellular matrix. Br J Dermatol 2012; 167:9806.

33 Blaustein M, Pelisch F, Coso OA et al. Mammary epithelialmesenchymal interaction regulates fibronectin alternative splicing via phosphatidylinositol 3-kinase. J Biol Chem 2004; 279:2102937.

34 Baelde HJ, Eikmans M, van Vliet AI et al. Alternatively spliced isoforms of fibronectin in immune-mediated glomerulosclerosis: the role of TGF $\beta$ and IL-4. J Pathol 2004; 204:248-57.

35 Strutz F, Zeisberg M, Hemmerlein B et al. Basic fibroblast growth factor expression is increased in human renal fibrogenesis and may mediate autocrine fibroblast proliferation. Kidney Int 2000; 57:1521-38.

36 Murakami M, Elfenbein A, Simons M. Non-canonical fibroblast growth factor signalling in angiogenesis. Cardiovasc Res 2008; 78:223-31.

37 Jarvelainen H, Sainio A, Koulu M et al. Extracellular matrix molecules: potential targets in pharmacotherapy. Pharmacol Rev 2009; 61:198-223.

38 Luu K, Greenhill CJ, Majoros A et al. STAT1 plays a role in TLR signal transduction and inflammatory responses. Immunol Cell Biol 2014; 92:761-9.

39 Bata-Csorgo Z, Szell M. The psoriatic keratinocytes. Expert Rev Dermatol 2012; 7:473-81.

40 Madonna S, Scarponi C, Sestito R et al. The IFN- $\gamma$-dependent suppressor of cytokine signaling 1 promoter activity is positively regulated by IFN regulatory factor-1 and Sp1 but repressed by growth factor independence- $1 \mathrm{~b}$ and Kruppel-like factor-4, and it is dysregulated in psoriatic keratinocytes. J Immunol 2010; 185:246781.
41 McKenzie RC, Sabin E. Aberrant signalling and transcription factor activation as an explanation for the defective growth control and differentiation of keratinocytes in psoriasis: a hypothesis. Exp Dermatol 2003; 12:337-45.

42 Bettelli E, Sullivan B, Szabo SJ et al. Loss of T-bet, but not STAT1, prevents the development of experimental autoimmune encephalomyelitis. J Exp Med 2004; 200:79-87.

43 Prinz M, Schmidt H, Mildner A et al. Distinct and nonredundant in vivo functions of IFNAR on myeloid cells limit autoimmunity in the central nervous system. Immunity 2008; 28:675-86.

44 Boroujerdi A, Welser-Alves JV, Milner R. Extensive vascular remodeling in the spinal cord of pre-symptomatic experimental autoimmune encephalomyelitis mice; increased vessel expression of fibronectin and the $\alpha 5 \beta 1$ integrin. Exp Neurol 2013; 250:43-51.

45 Ramana CV, Chatterjee-Kishore M, Nguyen H, Stark GR. Complex roles of Stat1 in regulating gene expression. Oncogene 2000; 19:2619-27.

46 Wagner AH, Wittjen I, Stojanovic T et al. Signal transducer and activator of transcription 1 decoy oligodeoxynucleotide suppression of contact hypersensitivity. J Allergy Clin Immunol 2008; 121:158-65.

\section{Supporting Information}

Additional Supporting Information may be found in the online version of this article at the publisher's website:

Appendix S1. Supplementary materials and methods.

Fig S1. Mild mechanical stress induced by tape stripping has no effect on the expression of $\alpha_{5}$ integrin, extra domain Acontaining fibronectin, keratinocyte growth factor or fibroblast growth factor receptor 2 in nonlesional psoriatic skin and only a mild effect on healthy skin.

Fig S2. Exogenous keratinocyte growth factor treatment has no effect on extra domain A-containing fibronectin expression of keratinocytes and HaCaT cells.

Fig S3. Fibroblasts and melanocytes show higher expression of extra domain A-containing fibronectin and fibronectin than keratinocytes.

Fig S4. Increase of extra domain A-containing fibronectin and fibronectin triggered by exogenous keratinocyte growth factor treatment is not influenced by Akt1/2 inhibition.

Table S1. List of genes applied for the construction of the coexpression matrix gene model.

Table S2. Coexpression matrix of genes in our model. 


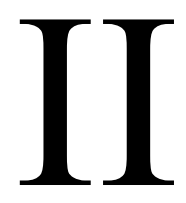




\title{
Abnormális STAT1 aktivitás pikkelysömörben
}

\section{Abnormal STAT1 activation in psoriasis}

\author{
GUBÁN BARBARA ${ }^{1}$, KUI RÓBERT DR. ${ }^{1}$, KÉPÍRÓ LÁSZLÓ DR. ${ }^{1}$, BEBES ATTILA DR. ${ }^{1}$, \\ GROMA GERGELY DR. ${ }^{1}$, KEMÉNY LAJOS DR. ${ }^{1,2}$, BATA-CSÖRGÓ ZSUZSANNA DR. ${ }^{1,2}$
}

Szegedi Tudományegyetem, Bőrgyógyászati és Allergológiai Klinika, Szeged, Magyarország MTA-SZTE Dermatológiai Kutatócsoport, Szeged, Magyarország²

\section{ÖSSZEFOGLALÁS}

A STAT (signal transducer and activator of transcription) jelátviteli útvonalak kulcsfontosságú szerepet töltenek be a pikkelysömör patomechanizmusában. Kutatócsoportunk megállapította, hogy a STAT1 aktivált állapotban van egészséges és tünetes börben, ellentétben a tünetmentes börrel, ahol jórészt inaktív. Tünetmentes börben a csökkent mértékü STAT1 aktiváció független a lézióktól való távolságtól. Az aktivált STAT1 korrelációt mutat a PASI (psoriasis area and severity index) értékével, minél magasabb a beteg PASI-ja, annál erösebb az aktivált STAT1 kifejeződése a börben. Korábbi vizsgálataink azt mutatták, hogy a STAT1 abnormálisan regulálódik a pikkelysömörös fibroblasztokban. Ezek az eredmények felvetik annak lehetöségét, hogy a STAT1 új terápiás célpont lehet a betegségben.

\section{Kulcsszavak: pikkelysömör - STAT1 - tünetmentes bőr}

\section{SUMMARY}

The STAT (signal transducer and activator of transcription) signalling pathway plays a key role in the pathogenesis of psoriasis. Our results indicate that STAT1 is active in both healthy and in psoriatic lesional skin and in contrast to the non-lesional skin where it is mainly inactive. The distance from the lesion does not affect STATl activity in the non-lesional skin. The STAT1 activation correlates with the PASI (psoriasis area and severity index) of psoriatic patients. In our previous work we have shown that STAT1 is abnormally regulated in psoriatic fibroblasts. These data indicate that STAT1 could be a potential new target for the therapy of the disease.

\section{Key words: psoriasis - STAT1- non-lesional skin}

A pikkelysömör egy multifaktoriális, krónikus bőrbetegség, amelynek kialakulásában és fenntartásában mind a veleszületett, mind az adaptív immunitás szerepet játszik (1). A pikkelysömörös bőrben az epidermális keratinociták túlzott proliferációja és abnormális differenciációja figyelhetố meg, mely megvastagodott epidermiszt, csökkent vagy hiányzó granuláris réteget eredményez. Emellett fokozottan infiltrálódó T-limfociták, neutrofilek és leukociták, emelkedett növekedési faktor, citokin és kemokin kifejezôdés figyelhető meg pikkelysömörös tünetes bőrben a celluláris immunrendszer aberráns aktivációjának köszönhetôen (2-4). A makroszkópikusan normális fenotípust mutató, tünetmentes pikkelysömörös bőr - saját és más kutatócsoportok eredményei szerint különbözô eltéréseket hordoz magában az egészségeshez képest $(5,6)$.

A kutatások szerint a pikkelysömör patogenezisében kulcsfontosságú szerepet töltenek be a JAK (Janus kináz)
- STAT (signal transducer and activator of transcription) jelátviteli útvonalak, amelyek transzkripciós faktorai abnormális expressziót és aktivációt mutatnak, ezzel hozzájárulnak a pikkelysömör gyulladásos folyamatainak kialakulásához (7, 8). A különbözô JAK-ok (JAK1, JAK2, JAK3, Tyk2) eltérô STAT fehérjékkel tudnak kapcsolatba lépni. A STAT család 7 egymással nagyfokú homológiát mutató tagból áll (STAT 1, 2, 3, 4, 5a, 5b és 6), specifikus aktivitást mutatnak, így a funkciójuk széles skálája figyelhető meg a JAK-STAT jelátviteli útvonalakon keresztül (9, 10). Számos gént képesek aktiválni, míg másokat gátolni, ezáltal hatással vannak olyan alapvetô celluláris folyamatokra, mint a sejtproliferáció és -differenciáció, a sejttúlélés, az apoptózis, a migráció és az angiogenezis (9). Aktivációjuk és deaktivációjuk precízen irányított, néhány óra alatt lezajló folyamat (11).

A STAT1 aktiválódása az interferon (IFN) két különbözô típusa, az IFN $\alpha$ és az IFN $\gamma$ által valósul meg, ame-

Levelezô szerzô: Gubán Barbara

e-mail: gubanbarbi@gmail.com 
lyek a JAK1, JAK2 vagy Tyk2 dimerizációját és autofoszforilációját okozzák (10, 12). A JAK-ok kialakult specifikus kötőhelyeihez kapcsolódó STAT1 molekulák foszforilálódnak, ezáltal aktiválódnak, és homovagy heterodimer formában a sejtmagba transzlokálódnak, ahol növelik számos, az immunfolyamatok szabályozásában részt vevő gén transzkripcióját, így több, mint 65 gén expressziója fokozódik, amely körülbelül a pikkelysömörben eltérô szinten expresszálódó gének 5\%-át teszi ki $(2,13,14)$. A STAT1 aktivációjához mind a $\operatorname{Tyr}(701)$, mind a Ser(727) aminosav foszforilációja szükséges. A Tyr701 foszforiláció elengedhetetlen a STAT1 dimerizációjához, míg a Ser(727) a DNSkötő affinitásért és a sejtmagba történố transzlokalizációért, ily módon az aktivitás kialakulásáért felelős $(15,16)$.

Korábban Hald és munkatársai leírták az aktivált STAT1 kifejeződését pikkelysömörös tünetes bốrben (17). Kutatócsoportunk megállapította, hogy a STAT1 aktív állapotban van jelen az egészséges és a pikkelysömörös tünetes bőrben egyaránt, ellentétben a tünetmentes bórrel, ahol jórészt inaktív formában található (18). Jelen vizsgálatok a pikkelysömörös bőr STAT1 aktivitásának részletesebb vizsgálatát célozták meg.

\section{Anyagok és módszerek}

\section{Punch biopsziák}

Három középsúlyos-súlyos plakk típusú pikkelysömörös beteget és három egészséges donort vontunk be a vizsgálatba a 18-60 éves korosztályból. A $6 \mathrm{~mm}$-es punch biopsziák vétele kezelés nélküli időszakban történt, legalább 4 héttel a szisztémás vagy lokális kezelést követóen. A PASI (psoriasis area and severity index) értékét minden betegnél bórgyógyász határozta meg. A tünetmentes területekről közvetlenül a lézió mellől (tünetmentes közeli) és a plakktól $10 \mathrm{~cm}$-re (tünetmentes távoli) vettünk mintákat. A szöveti minták gyújtése eleget tett a Helsinki deklarációnak és a Népegészségügyi Szakigazgatási Szerv szabályainak $(2799,3517)$.

\section{Immunhisztokémiai festés}

A punch biopsziákat paraffinba ágyaztuk és szobahőmérsékleten tároltuk, majd 5 um vastagságú metszeteket készítettünk. A metszeteket deparaffináltuk és leszálló alkoholsort alkalmazva rehidratáltuk a mintákat, ezt követôen pH 6-os citrát pufferrel tártuk fel 95 ${ }^{\circ} \mathrm{C}$-on 10 percig. A metszeteket 20 percig $0,1 \% \mathrm{H}_{2} \mathrm{O}_{2}$-ot és $0,6 \%$ $\mathrm{NaN}_{3}$-ot (Sigma-Aldrich) tartalmazó PBS-sel, majd 30 percig kecske szérumot tartalmazó pufferrel (Invitrogen/ Thermo Fisher Scientific) blokkoltuk. Ezt követôen pSTAT1 Ser(727) és pSTAT1 Tyr(701), (mindkettő 1:400 hígításban, Cell Signaling Technology)
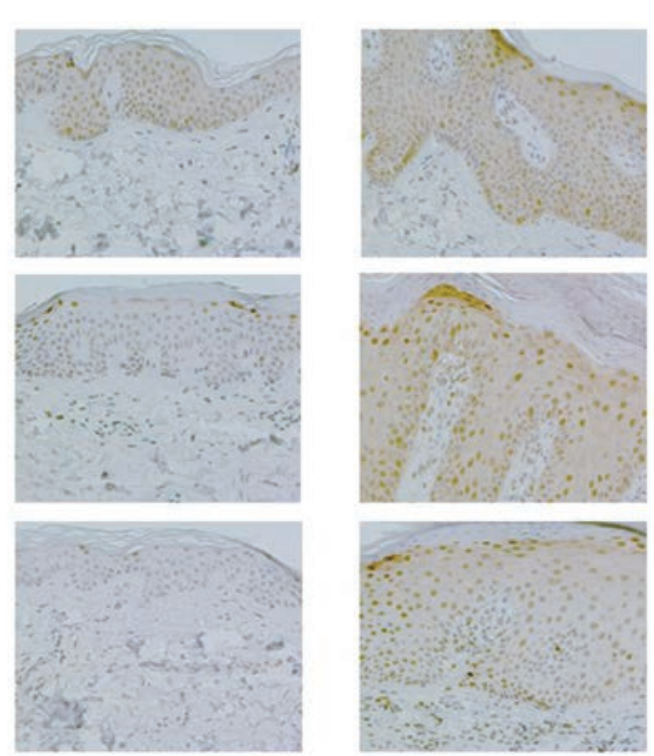

tünetes

\section{1. ábra}

munhisztokémiai festéssel vizsgálva a pSTAT1 Ser(727) formája nagyfokú míg tünetmentes bőrben szinte alig detektálható. A magas PASI-jú betegek ár tartalmaz aktivált STAT1-et, ellentétben az alacsony PASI-jú tünetmentes bőrrel $(\mathrm{n}=3)$

elsődleges ellenanyagokkal egész éjszakán át $4^{\circ} \mathrm{C}$-on inkubáltuk. A metszeteket PBS-ben mostuk, majd biotinilált kecske anti-nyúl ellenanyaggal inkubáltuk szobahốmérsékleten 30 percig (1:300, DAKO An Agilent Technologies Company). Újabb PBS-es mosást követôen streptavidin/biotin komplexszel (ABC kit, Enzo Life Sciences Inc.) inkubáltuk 20 percig. Negatív festési kontrollként elsődleges ellenanyag nélküli, csupán PBS-sel inkubált mintát használtunk. Az előhívást 3,3'-diaminobenzidin-nel (DAB) végeztük. A sejtmag és a citoplazma festése hematoxilin-eozinnal (SigmaAldrich) történt.

\section{Eredmények}

A paraffinos mintákon immunhisztokémiai festéssel vizsgált pSTAT1 Ser(727) forma kifejezôdése mind az epidermiszben, mind a dermiszben megfigyelhetô (1. ábra). A STAT1 aktivitása korrelál a PASI értékével; magas PASI esetén (pl. 19,6) a tünetes bőrben intenzívebb STAT1 kifejeződés tapasztalható, és ezeknél az eseteknél a tünetmentes bőr is kismértékú STAT1 aktivitást mutat, míg alacsony PASI-val bíró betegek (pl. 9,8) esetében ez nem volt megfigyelhető. Tünetmentes bőrben a pSTAT1 Ser(727) forma kifejeződése és a betegek PASI értéke párhuzamos csökkenést mutat. A pSTAT1 Tyr(701) formájának aktivációja nagyon gyorsan lezajlik, ezért csak magas PASI-jú betegek mintáin figyelhető meg, ahol 


\begin{tabular}{|c|c|c|c|c|c|c|c|c|c|c|c|c|c|}
\hline \multirow[b]{3}{*}{ BETEG } & \multirow[b]{3}{*}{ PASI } & \multicolumn{6}{|c|}{ pSTAT1 (Ser 727) } & \multicolumn{6}{|c|}{ pSTAT1 (Tyr701) } \\
\hline & & \multicolumn{2}{|c|}{ TM (távoli) } & \multicolumn{2}{|c|}{ TM (közeli) } & \multicolumn{2}{|c|}{$\mathbf{T}$} & \multicolumn{2}{|c|}{ TM (távoli) } & \multicolumn{2}{|c|}{ TM (közeli) } & \multicolumn{2}{|c|}{$\mathbf{T}$} \\
\hline & & $\mathbf{E}$ & D & $\mathbf{E}$ & D & $\mathbf{E}$ & D & $\mathbf{E}$ & D & $\mathbf{E}$ & D & $\mathbf{E}$ & D \\
\hline 1 & 19,6 & + & + & + & - & + & + & - & - & $+1-$ & $+/-$ & - & - \\
\hline 2 & 12,4 & $+1-$ & $+1-$ & $+1-$ & $+1-$ & + & + & - & - & - & - & - & - \\
\hline 3 & 9,8 & - & - & - & - & + & + & - & - & - & - & - & - \\
\hline
\end{tabular}

1. táblázat

A táblázat a pSTAT1 Ser(727) és a pSTAT1 Tyr(701) formák aktivációját mutatja tünetmentes és tünetes bőr epidermiszében és dermiszében, hozzárendelve a 3 vizsgált pikkelysömörös beteg PASI értékeit. TM: tünetmentes, T: tünetes, E: epidermisz, D: dermisz; +: erôs pozitivitás, +/-: gyenge pozitivitás, -: negatív

mindkét foszforilációs forma aktivációja jóval intenzívebb (1. táblázat). Összehasonlítotva a tünetmentes lézióhoz közeli és attól távoli területekrôl vett punch biopsziák pSTAT1 formáinak kifejeződését, megfigyelhető, hogy a STAT1 aktivitása független a lézióktól való távolságtól $(\mathrm{n}=3)$ (1. ábra). Az ábrán az is látható, hogy a STAT1 aktiváció legerősebben a pikkelysömörös tünetes bőrben mutatható ki. Bár a tünetmentes bőrben a STAT1 jórészt inaktív, aktivációja magas PASI érték esetén már az egészséges bőrben tapasztalthoz hasonló mértéket mutat.

\section{Megbeszélés}

Jelenleg a legtöbb kutatás pikkelysömörben a JAKSTAT jelátviteli útvonal köré csoportosul. A STAT család tagjai többféle funkciót töltenek be a veleszületett immunitásban. A STAT1 az IFN, az IL-27, az IL-35 és a TLR közvetített jelátvitelen keresztül aktiválódik (19). Számos tanulmány beszámol az IFN $\gamma$ jelátvitel fontosságáról a pikkelysömör patomechanizmusában (20). A STAT1 számos gén transzkripciós aktivációját okozza, míg más gének expresszióját antagonista módon befolyásolja, így kialakítva egy komplex szignál választ (21). Pikkelysömörös keratinocitákban a STAT1, az IRF1 (interferon regulated factor 1) és a SOCS1 (az IFN $\gamma$ szignaling negatív regulátora) transzkripciós faktorok aberráns regulációja kontrollálatlan növekedéshez és differenciációhoz vezethet $(7,22)$.

Kutatócsoportunk korábbi eredményei azt mutatták, hogy az egészséges egyének bőréből származó tenyésztett fibroblasztokban az aktivált STAT1 szükséges a fibronektin (FN1) és az onkofötális fibronektin $\left(\mathrm{EDA}^{+} \mathrm{FN}\right)$ termelés gátlásához, és a STAT1 gátlása fokozott FN1 és $\mathrm{EDA}^{+} \mathrm{FN}$ kifejeződést eredményez normál humán fibroblasztokban. Pikkelysömörös fibroblasztokban ezzel ellentétben nem figyelhető meg az aktivált STAT1 FN1 és $\mathrm{EDA}^{+} \mathrm{FN}$ kifejeződést gátló funkciója (18). Eredményeink alapján feltételezhető, hogy a pikkelysömörös bőrben leírt fokozott FN és EDA ${ }^{+}$FN kifejeződés $(6,23)$ hátterében részben a STAT1 abnormális funkciója állhat. Az aktivált STAT1 kifejezôdése a normál bőrben arra utal, hogy a szövet homeosztatikus állapotának fenntartásában a STAT1 aktiváció szerepet játszik. Az a tény, hogy a tünetmentes bőrben a STAT1 jórészt inaktivált állapotban van jelen, szintén a STAT1 aberráns múködésére utal a betegségben.
A JAK-STAT jelátviteli útvonal proinflammatorikus folyamatainak gátlása kulcsfontosságú lehet az immun-mediált bőrbetegségek patogenezisében. Hármas fázisú klinikai vizsgálatok folynak kis molekulájú JAK gátlók (tofacitinib, ruxolitinib) potenciális terápiaként való hatékony és biztonságos alkalmazhatóságának megítélésére a pikkelysömör kezelésében. Az I. és II. fázis tanulmányok eredményei dózisfüggő javulást mutattak a pikkelysömörös léziók súlyosságának mértékében a placebo csoporthoz viszonyítva. Számos STAT inhibitorról beszámoltak az irodalomban (24), azonban STAT1 gátlót még csak állatmodellekben használtak. Wagner és munkatársai hapten-indukálta kontakt hiperszenzitivitást gátoltak STAT1 decoy oligodeoxynukleotidot (dODN) tartalmazó krémmel (25).

Eredményeink arra engednek következtetni, hogy a STAT1 molekula kulcsfontosságú lehet a pikkelysömörre való hajlam kialakításában. A pathomechanizmusban betöltött szerepének pontos felderítése további vizsgálatokat kíván.

A munka elvégzéséhez az OTKA K83277, K105985, K111885, NK105369, PD116992, TÁMOP-4.2.4.A/2-11-1/2012-0001 és A2SZGYA-FOK-13-0001 pályázatok nyújtottak segítséget.

\section{IRODALOM}

1. Bos J.D., de Rie M. A., Teunissen M. B. et al: Psoriasis: dysregulation of innate immunity. Br. J Dermatol. (2005) 152, 10981107.

2. Krueger J. G., Bowcock A.: Psoriasis pathophysiology: current concepts of pathogenesis. Ann Rheumat Dis (2005) 64 Suppl 2, ii30-36.

3. Lowes M. A., Bowcock A. M., Krueger J. G.: Pathogenesis and therapy of psoriasis. Nature (2007) 445, 866-873.

4. Nograles K. E., Davidovici B., Krueger J. G.: New insights in the immunologic basis of psoriasis. Seminars in cutaneous medicine and surgery (2010) 29, 3-9.

5. Pellegrini G., De Luca M., Orecchia G. et al.: Expression, topography, and function of integrin receptors are severely altered in keratinocytes from involved and uninvolved psoriatic skin. J Clin Invest (1992) 89,1783-1795.

6. Bata-Csorgo Z., Cooper K. D., Ting K. M. et al.: Fibronectin and alpha5 integrin regulate keratinocyte cell cycling. A mechanism for increased fibronectin potentiation of $\mathrm{T}$ cell lymphokinedriven keratinocyte hyperproliferation in psoriasis. J Clin Invest (1998) 101, 1509-1518.

7. McKenzie R. C., Sabin E.: Aberrant signalling and transcription factor activation as an explanation for the defective growth control and differentiation of keratinocytes in psoriasis: a hypothesis. Exp Dermatol (2003) 12, 337-345. 
8. van der Fits L., van der Wel L. I., Laman J. D. et al.: In psoriasis lesional skin the type I interferon signaling pathway is activated, whereas interferon-alpha sensitivity is unaltered. J Invest Dermatol (2004) 122, 51-60.

9. Rawlings J. S., Rosler K. M., Harrison D. A.: The JAK/STAT signaling pathway. J Cell Sci (2004) 117, 1281-1283.

10. Darnell J. E. Jr.: STATs and gene regulation. Science (1997) 277 , 1630-1635.

11. Furqan M., Mukhi N., Lee B. et al.: Dysregulation of JAK-STAT pathway in hematological malignancies and JAK inhibitors for clinical application. Biomark Res (2013) 1, 5.

12. Igarashi K., Garotta G., Ozmen L. et al.: Interferon-gamma induces tyrosine phosphorylation of interferon-gamma receptor and regulated association of protein tyrosine kinases, Jak1 and Jak2, with its receptor. J Biol Chem (1994) 269, 14333-14336.

13. Ghoreschi K., Laurence A., O'Shea J.J.: Janus kinases in immune cell signaling. Immunol Rev (2009) 228, 273-287.

14. Shuai K., Liu B.: Regulation of JAK-STAT signalling in the immune system. Nat Rev Immunol (2003) 3, 900-911.

15. Decker T., Kovarik P.: Serine phosphorylation of STATs. Oncogene (2000) 19, 2628-2637.

16. Uddin S., Sassano A., Deb D. K. et al.: Protein kinase C-delta (PKCdelta ) is activated by type I interferons and mediates phosphorylation of Stat1 on serine 727. J Biol Chem (2002) 277, 14408-14416.

17. Hald A., Andres R. M., Salskov-Iversen M. L.: STAT1 expression and activation is increased in lesional psoriatic skin. Br. J Dermatol. (2013) 168, 302-310.

18. Guban B., Vas K., Balog Z. et al.: Abnormal regulation of fibronectin production by fibroblasts in psoriasis. Br J Dermatol 2015 Oct 15. doi: 10.1111/bjd.14219. [Epub ahead of print].
19. Lии K., Greenhill C. J., Majoros A. et al.: STAT1 plays a role in TLR signal transduction and inflammatory responses. Immunol Cell Biol (2014) 92, 761-769.

20. Albanesi C., Scarponi C., Giustizieri M. L. et al.: Keratinocytes in inflammatory skin diseases. Curr Drug Targets Inflamm Allergy (2005) 4, 329-334.

21. Ramana C. V., Chatterjee-Kishore M., Nguyen H. et al.: Complex roles of Stat 1 in regulating gene expression. Oncogene (2000) 19, 2619-2627.

22. Madonna S., Scarponi C., Sestito R. et al.: The IFNgamma-dependent suppressor of cytokine signaling 1 promoter activity is positively regulated by IFN regulatory factor- 1 and Sp1but repressed by growth factor independence-1b and Krüppel-like factor-4, and it is dysregulated in psoriatic keratinocytes. J Immunol (2010) 185, 2467-2481.

23. Ting K. M., Rothaupt D., McCormick T. S. et al.: Overexpression of the oncofetal Fn variant containing the EDA splice-in segment in the dermal-epidermal junction of psoriatic uninvolved skin. J Invest Dermatol (2000) 114, 706-711.

24. Nelson E. A., Sharma S. V., Settleman J. et al.: A chemical biology approach to developing STAT inhibitors: molecular strategies for accelerating clinical translation. Oncotarget (2011) 2, 518-524.

25. Wagner A. H., Wittjen I., Stojanovic T. et al.: Signal transducer and activator of transcription 1 decoy oligodeoxynucleotide suppression of contact hypersensitivity. J Allergy Clin Immunol (2008) $121,158-165$ e5.

Érkezett: 2016. 01. 11.

Közlésre elfogadva: 2016. 01. 18.

\section{Hazai Hírek}

Az MDT Kontakt Dermatitis Munkacsoport 2015. évi ülését a Magyar Dermatológiai Társulat Nagygyúlésén november 28-án tartotta meg.

Az MDT 88. Tudományos Ülésén önálló szekcióban elhangzott előadások: a fogászati kontakt allergének tesztelési lehetôségeirôl ( $d r$. Baló Mátyás), az állati szôrök okozta kontakt szenzibilizációk diagnosztikus nehézségéről, klinikumáról ( $r$ r. Nagy Gabriella), a hajfestékek okozta igen erôs, hospitalizációs kezelésre szoruló kontakt szenzibilizációiról (dr. Koller Ágnes Hanna), az MI és a Katon CG szenzibilizáció aktuális adatairól ( $d r$. Pónyai Györgyi), a higany allergia jelenleg is tapasztalható gyakorlati jelentőségérôl (dr. Fábos Beáta) szóltak.

A kontakt szenzibilizáció tesztelésének értékelési idejére vonatkozó (hazánkban 2007-től alkalmazott) metodikai előírásairól önálló előadás hangzott el, hivatkozva az ezzel megegyező 2015 novemberében megjelent európai guideline előírásaira, kiemelve a 7., alkalmanként a 10 napig javasolt tesztreakció követést. Az előadó részletezte az epicutan próbák okozta - elenyészőnek mondható - mellékhatások lehetôségeit, ezek megelôzésében hangsúlyozta a standard metodika és standard tesztanyagok előnyeit (dr. Temesvári Erzsébet).

A szekció ülést követően a Munkacsoport az elmúlt év multicentrikus vizsgálatát beszélte meg, melynek során a hazai epicutan sorba bevezetett methilizotiazolin (MI) tesztelés eredményeit értékelte.

A Munkacsoport felhívta a figyelmet a 2007-tôl alkalmazott hazai tesztelési metodikának megfelelő európai guideline (Contact Dermatitis 2015. 73,195) epicutan teszt értékelés kritériumára, mely szerint a bőrtesztek értékelése 20-60 perc, 48 óra, 72 vagy 96 óra és a 7. nap. Hangsúlyozta az egységes tesztelési metodika jelentőségét a kiadott teszteredmények - alkalmanként szükséges - szakvéleményezésében.

A Munkacsoport a Magyar Sor antigénjeit - melyek jelenleg európai guidelinenek megfelelnek - nem bővítette.

Budapest, 2015. november 30.

Prof. Dr. Temesvári Erzsébet

egyetemi tanár, a Munkacsoport vezetôje 